$$
\begin{aligned}
& \text { UNIVERSIDADE DE BRASÍLIA } \\
& \text { INSTITUTO DE ARTES } \\
& \text { DEPARTAMENTO DE MÚSICA }
\end{aligned}
$$

\title{
EVASÃO NA EAD: UM SURVEY COM ESTUDANTES DO CURSO DE LICENCIATURA EM MÚSICA A DISTÂNCIA DA UNB
}

JAÍNE GONÇALVES ARAUJO

BRASÍLIA 


\section{EVASÃO NA EAD: UM SURVEY COM ESTUDANTES DO CURSO DE LICENCIATURA EM MÚSICA A DISTÂNCIA DA UNB}

Dissertação apresentada ao Programa de Pósgraduação em Música do Departamento de Música da Universidade de Brasília, como requisito parcial para obtenção do grau de Mestre em Música.

Área de concentração: Educação Musical.

Orientador: Prof. Dr. Paulo Roberto Affonso Marins 
Ficha catalográfica elaborada automaticamente, com os dados fornecidos pelo(a) autor(a) DE LICENCIATURA BM MÚSICA A DISTÂNCIA DA UNB / Jaíne Gonçalves Araujo; orientador Paulo Roberto Affonso Marins. -- Brasília, 2015. $109 \mathrm{p}$.

Dissertação (Mestrado - Mestrado em Música) -Universidade de Brasilia, 2015.

1. Educação a Distância. 2. Universidade Aberta do Brasil. 3. Evasão em Cursos a Distância. 4. Licenciatura em Música a Distância da Universidade de Brasilia. 5. Bvasão em Curso de Música. I. Marins, Paulo Roberto Affonso, orient. II. Título. 


\section{JAÍNE GONÇALVES ARAUJO}

\section{EVASÃO NA EAD: UM SURVEY COM ESTUDANTES DO CURSO DE LICENCIATURA EM MÚSICA A DISTÂNCIA DA UNB}

Dissertação apresentada ao Programa de Pósgraduação em Música do Departamento de Música da Universidade de Brasília, como requisito parcial para obtenção do grau de Mestre em Música. Área de concentração: Educação Musical.

Orientador: Prof. Dr. Paulo Roberto Affonso Marins

Banca Examinadora

\footnotetext{
Paulo Roberto Affonso Marins (Orientador) Universidade de Brasília - UnB
Maria Cristina de Carvalho Cascelli de Azevedo (Membro Interno)
Universidade de Brasília - UnB
Maria Alexandra Militão Rodrigues
(Membro Externo)
Universidade de Brasília - UnB
Ricardo Dourado Freire (Suplente)
Universidade de Brasília - UnB

Aprovado em de de 2015 
Aos meus pais, llidio e Lucia, e aos meus irmãos, Jailtom e Alexandre, dedico este trabalho. 


\section{AGRADECIMENTOS}

Agradeço a Deus pelo dom da vida e por me dar perseverança durante minha passagem pela UnB.

À Nossa Senhora Aparecida pela intercessão.

À minha família por todas as demonstrações de afeto, respeito e apoio; em especial aos meus pais, llidio e Lucia, pela dedicação.

Ao meu orientador Paulo Marins, por acreditar no potencial da pesquisa, colaborar no meu desenvolvimento acadêmico, pela orientação, direcionamento e pela compreensão do meu processo de aprendizagem.

Aos professores do Departamento de Música da Universidade de Brasília, pela contribuição na minha formação.

Aos colegas de mestrado, em especial Daniel Baker, Heverson Nogueira, Josilaine Gonçalves, Maria Débora Ortiz e Rosa Barros, Hermes Siqueira e Marise Barbosa pelas partilhas e pela amizade.

Aos amigos Jeane Pedrozo, Fernando Botelho, llka Torres, Kiara Zancanaro, Lívia Veleda e Wilsa Ramos pela escuta nos momentos difíceis.

Ao meu amigo Rogério Diniz de Freitas (in memoriam), pela amizade, por acreditar no meu potencial e por me impulsionar a alcançar os meus sonhos acadêmicos e musicais.

Aos meus familiares e amigos pela compreensão e apoio nos momentos em que estive ausente.

Aos servidores da UnB, do Programa de Pós-Graduação em Música e Secretaria da UAB do curso de Música, pelo suporte acadêmico necessário.

Aos professores Dra. Maria Alexandra Militão Rodrigues, Dra. Maria Cristina de Carvalho C. de Azevedo e Dr. Ricardo Dourado Freire, pela gentileza de terem aceitado o convite para a banca de defesa desta dissertação;

Aos alunos evadidos da turma de UAB3, do curso de Licenciatura em Música a distância da UnB, por dedicarem um tempo precioso para participar da minha pesquisa;

À música, por ter se valido deste mestrado para me resgatar. 


\section{RESUMO}

O objetivo da presente pesquisa consiste em identificar e analisar os fatores que causam evasão dos alunos do curso de Licenciatura em Música a Distância da Universidade de Brasília (UnB). Para isso foi feita uma pesquisa utilizando a metodologia survey, na qual foi aplicado um questionário via ligação telefônica e email, a fim de fazer a coleta de dados. A fundamentação teórica parte dos princípios de educação a distância, educação musical e evasão. O texto apresenta a forma de implantação do Sistema Universidade Aberta do Brasil na UnB, como o Departamento do Curso de Licenciatura em Música trabalha com esse sistema e a influência da evasão nesse contexto. A análise dos dados permitiu conhecer os fatores que levaram os alunos a desistirem da conclusão do curso como a falta de tempo e dificuldades na realização das disciplinas. Espera-se que esta pesquisa possa contribuir com as pesquisas na área de educação a distância, evasão, educação musical e na formação a distância do professor de música.

Palavras-chave: Educação a Distância, Universidade Aberta do Brasil, Evasão em Cursos a Distância, Licenciatura em Música a Distância da Universidade de Brasília, Evasão em Cursos de Música. 


\section{ABSTRACT}

The aim of this research is to identify and analyze the factors that cause dropout of students in the Bachelor's Degree in Music Distance from the University of Brasilia (UNB). For this research was done using the survey methodology, which a questionnaire was administered via telephone and e-mail connection to data collection. The theoretical basis address principles of distance education, musical education and evasion. The text presents the form of implementation of the System Open University of Brazil at UNB, as the Department's Degree in Music Course work with this system and the influence of evasion in this context. Data analysis allowed to know the factors that caused students to dropout of graduation as lack of time and difficulties in carrying out disciplines. It is hoped that this research will contribute to the research in education the distance, evasion, musical education and distance learning music teacher.

Keywords: Distance Education, Open University of Brazil, Evasion in Distance Learning Courses, Distance Degree in Music at the University of Brasilia, Evasion in Music Courses. 


\section{LISTA DE ILUSTRAÇÕES}

Quadro 1 - EAD na UnB na década de 1980 .................................................. 25

Quadro 2 - Modelos de educação a distância - Estrutura conceitual ................... 27

Quadro 3 - Definição de evasão e amplitude do conceito ...................................... 40

Quadro 4 - Questões do questionário Evasão em Música .................................... 58

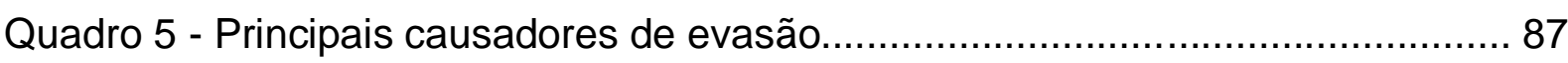

Figura 1 - Um esquema conceitual para o abandono no ensino superior segundo

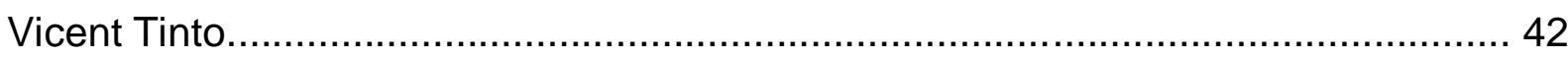

Gráfico 1 - Percentual de Evasão por curso - Oferta de 2007 ............................. 50 


\section{LISTA DE TABELAS}

Tabela 1 - Dados da evasão do Curso de Música a Distância da UnB 15

Tabela 2 - Dados quantitativos dos alunos do Curso de Música a Distância da UnB

Tabela 3 - Dados dos vestibulares do curso de Licenciatura em Música a Distância da UnB 30

Tabela 4 - Oferta de vagas do $1^{\circ}$ vestibular para o Curso de Licenciatura em Música a Distância da UnB

Tabela 5 - Oferta de Vagas do 2ำ Vestibular do Curso de Licenciatura em Música a

Distância da UnB 33

Tabela 6 - Oferta de Vagas do $3^{\circ}$ Vestibular do Curso de Licenciatura em Música a Distância da UnB 34

Tabela 7 - Oferta de Vagas do 4ํㅡㄴ Vestibular do Curso de Licenciatura em Música a Distância da UnB 34

Tabela 8 - Alunos ingressantes do Curso de Licenciatura em Música a Distância por

Polo 35

Tabela 9 - Índices de evasão registrados no período 2010-2013 pelo Censo EAD.BR realizados pela $A B E D$

Tabela 10 - Dados da evasão do Curso de Música a Distância da UnB 50

Tabela 11 - Quantitativo de alunos da Turma UAB3 53

Tabela 12 - Quantitativo e percentual de resposta do questionário 62

Tabela 13 - Perfil dos alunos - gênero, estado civil, filhos 63

Tabela 14 - Perfil dos alunos - idade por média 64

Tabela 15 - Perfil dos alunos - idade por categoria 64

Tabela 16 - Perfil dos alunos - escolaridade e profissão 64

Tabela 17 - Perfil dos alunos - horas trabalhadas 64

Tabela 18 - Perfil dos alunos - polo 65

Tabela 19 - Questão 1 do questionário 67

Tabela 20 - Questão 2 do questionário 68

Tabela 21 - Questão 3 do questionário 68

Tabela 22 - Questão 4 do questionário 69

Tabela 23 - Questão 5 do questionário 69 
Tabela 24 - Questão 6 do questionário 70

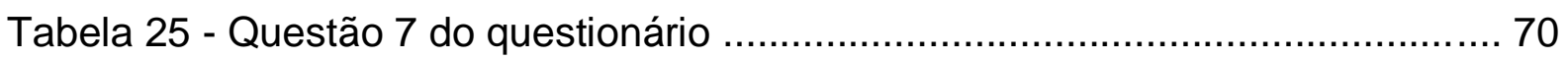

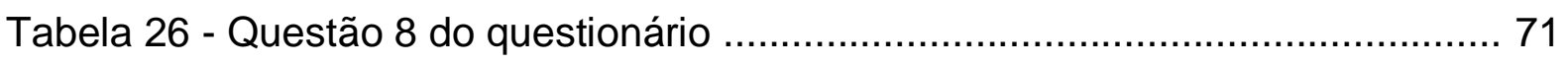

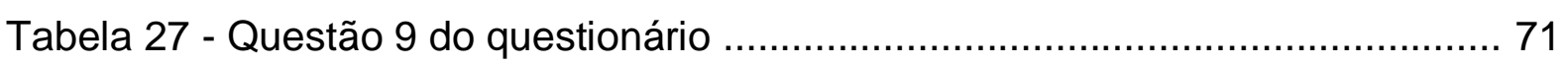

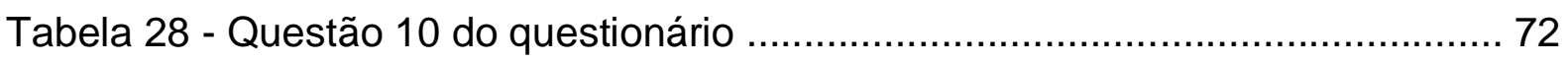

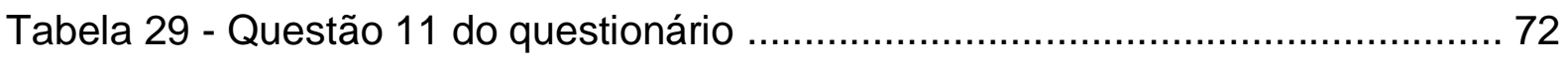

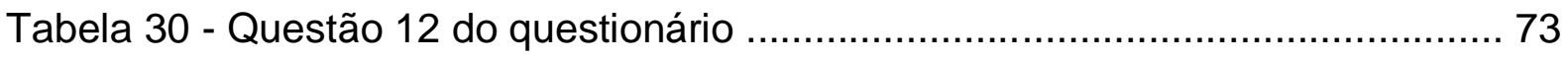

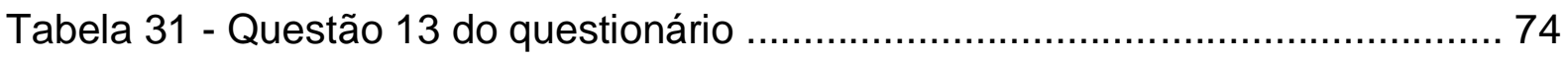

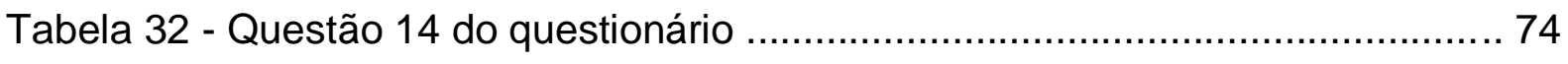

Tabela 33 - Questão 15 do questionário .......................................................... 75

Tabela 34 - Questão 16 do questionário ……………….................................. 75

Tabela 35 - Questão 17 do questionário .......................................................... 76

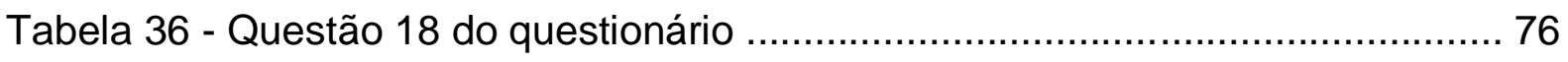

Tabela 37 - Questão 19 do questionário …………............................................... 77

Tabela 38 - Questão 20 do questionário ……………….................................. 77

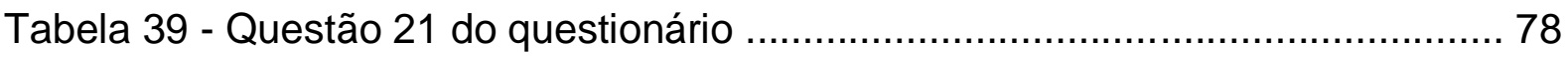

Tabela 40 - Questão 22 do questionário .......................................................... 78

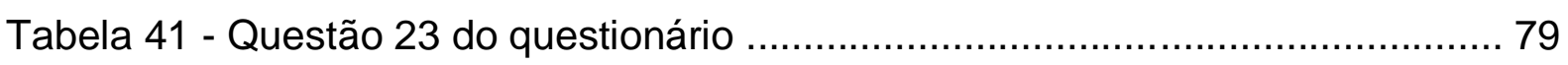

Tabela 42 - Questão 24 do questionário ............................................................ 79

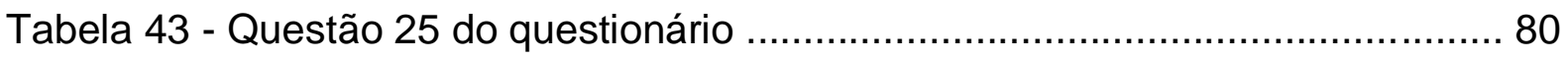

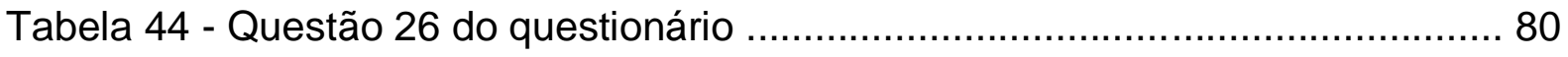

Tabela 45 - Questão 27 do questionário ……………................................... 80

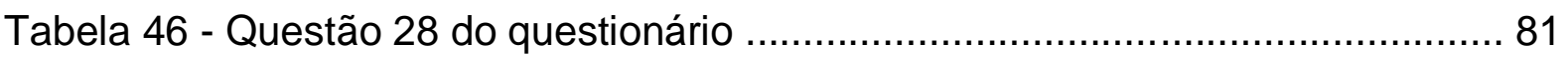

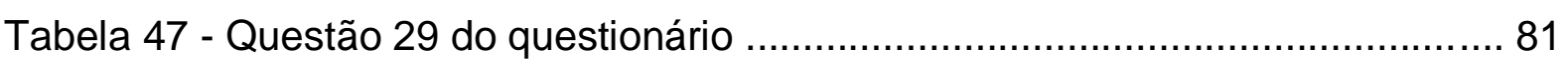

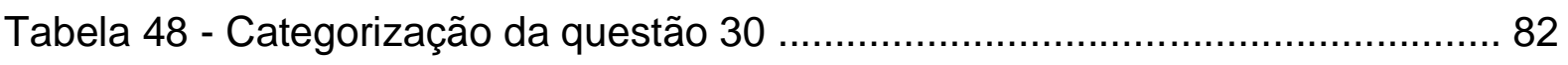




\section{LISTA DE SIGLAS}

AVA - Ambiente Virtual de Aprendizagem

BRASILEAD - Consórcio Brasileiro de Educação a Distância

CEAD - Centro de Educação a Distância

CNE - Conselho Nacional de Educação

CPCE - Centro de Produção Cultural e Educativa

DCN - Diretrizes Curriculares Nacionais

DEX - Decanato de Extensão

EAD - Educação a Distância

ENEM - Exame Nacional do Ensino Médio

FE - Faculdade de Educação

GEM - Grupo de Educação Musical

IdA - Instituto de Artes

IP - Programa de Pós-Graduação do Instituto de Psicologia

MEC - Ministério da Educação

MOODLE - Modular Object Oriented Dynamic Learning Environment

MUS - Departamento de Música

PED - Programa Ensino a Distância

PNAP - Programa Nacional de Formação em Administração Pública

PPP - Projeto Político Pedagógico

SECAD - Secretaria de Educação Continuada, Alfabetização e Diversidade

SIGRA - Sistema de Informações Acadêmicas de Graduação

TIC - Tecnologias da Informação e Comunicação

TRCC - Trabalho e Recital de Conclusão de Curso

UAB - Universidade Aberta do Brasil

UAB/UnB - Coordenação Geral do Sistema Universidade Aberta do Brasil na Universidade de Brasília

UnB - Universidade de Brasília 


\section{SUMÁRIO}

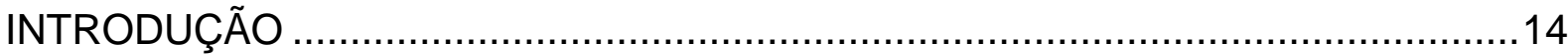

CAPÍTULO 1 - HISTÓRIO DO SISTEMA UNIVERSIDADE ABERTA DO BRASIL NA UNIVERSIDADE DE BRASÍLIA E EM SEU DEPARTAMENTO DE MÚSICA ...........20

1.1 Histórico do Sistema Universidade Aberta do Brasil ........................................20

1.2 Implantação do Sistema Universidade Aberta do Brasil na UnB ......................23

1.3 Histórico do Curso de Licenciatura em Música a Distância da Universidade de

Brasília 29

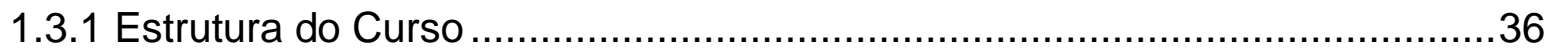

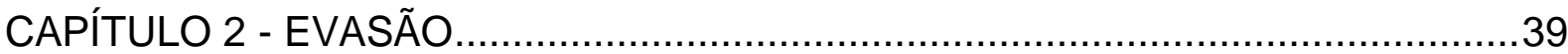

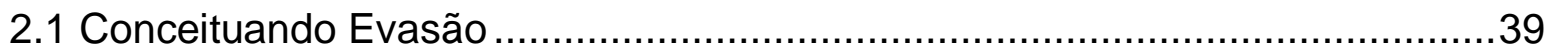

2.1.1 Modelo de Evasão no Ensino Superior .................................................. 40

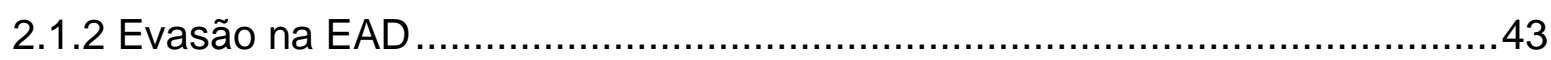

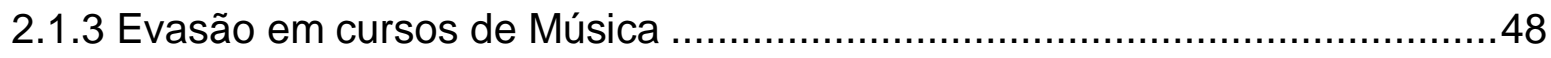

2.2 Evasão no Curso de Licenciatura em Música a Distância da UnB....................48

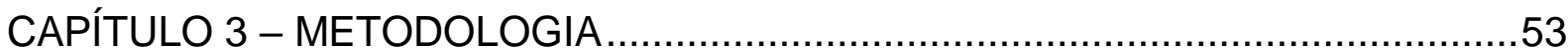

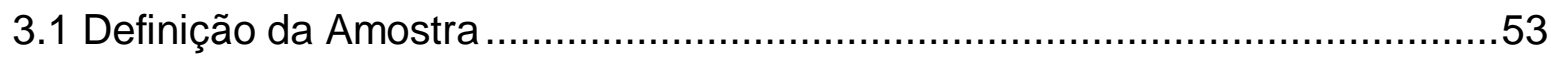

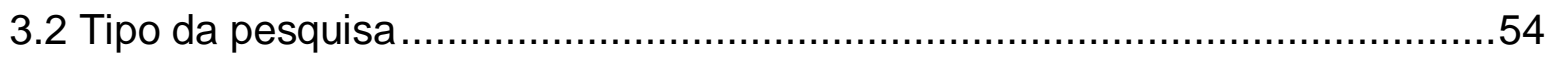

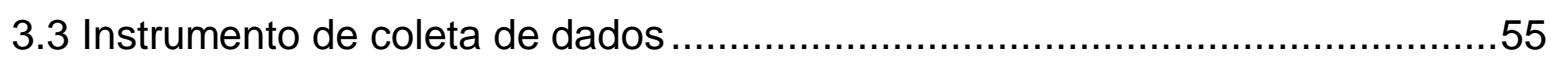

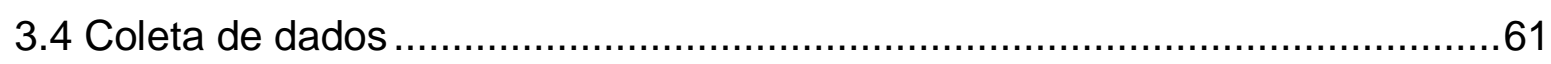

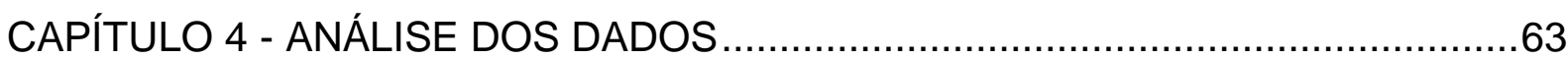

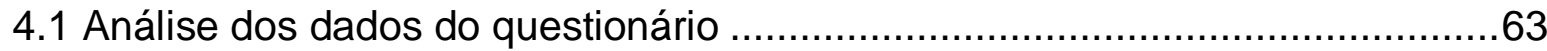

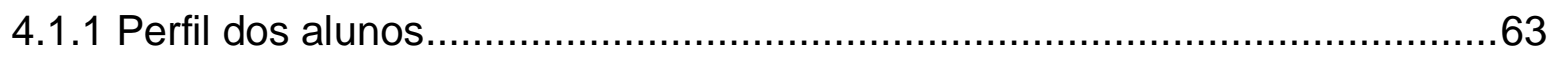

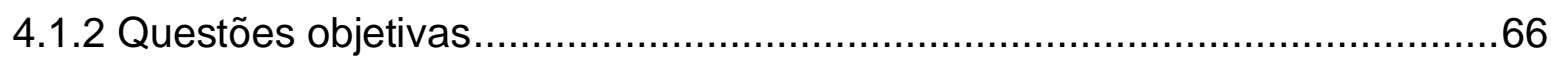

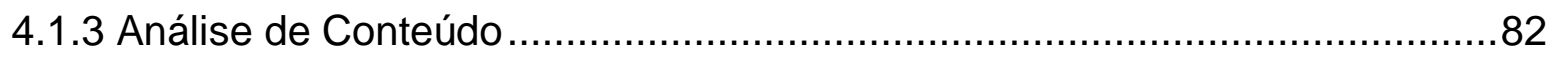

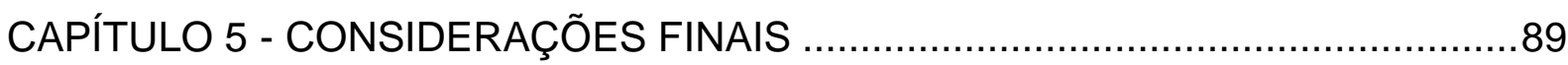

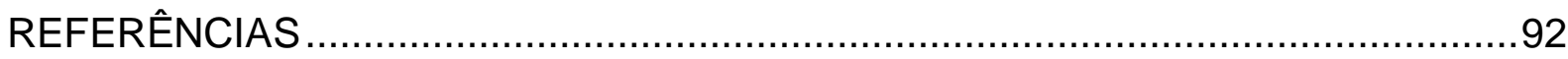

APÊNDICE 


\section{INTRODUÇÃO}

A educação a distância (EAD), ao longo de sua história, tem sido utilizada em diversos contextos e níveis de formação. Atualmente, se apresenta como modalidade de ensino importante para o desenvolvimento do ensino superior no Brasil. Ela é uma modalidade de ensino e aprendizagem com possibilidades de democratizar o acesso à formação e, de acordo com Nunes (2009, p. 2), "apresenta notáveis vantagens sob o ponto de vista da eficiência e da qualidade", visto que consegue alcançar pessoas que moram longe dos grandes centros; e outras que pela rotina de trabalho ou familiar, não conseguem frequentar um curso presencial.

A EAD chegou ao Brasil em meados da década de 1970, desenvolveu-se ao longo dos últimos 40 anos e passou pelas 5 gerações até chegar à modalidade online que é a mais utilizada atualmente (veja no quadro1, p. 19). Devido ao papel ocupado pela modalidade, várias pesquisas têm sido desenvolvidas sobre os processos de ensino e aprendizagem por meio da EAD e no intuito de colaborar com essas pesquisas este trabalho de mestrado teve início.

Variados são os processos didático-pedagógicos que envolvem a oferta de um curso a distância, bem como variados são os seus resultados. Nesta pesquisa, estudou-se um fenômeno chamado evasão: resultado do distanciamento definitivo do aluno e seu curso. A evasão em cursos a distância é o tema estruturante dessa pesquisa e tem apresentado relevância na área. De acordo com Xenos, Pierrakeas e Pintelas (2002):

A investigação dos fatores relacionados a taxas de abandono escolar e as causas de abandono pode ajudar toda a equipe envolvida no ensino aberto e à distância a especificar os grupos de estudantes propensos ao abandono. Isto poderá permitir os professores lidar com os grupos de alto risco de forma mais eficiente e minimizar desistências do estudante. (XENOS, PIERRAKEAS E PINTELAS, 2002, p.2)

A evasão dos estudantes em cursos dentro da EAD tem um histórico de altos índices. Contudo, no Brasil, o último censo de EAD data de 2013 e aponta uma evasão média de $16,94 \%$ de evasão em cursos autorizados ${ }^{1}$.

\footnotetext{
${ }^{1} \mathrm{http} / /$ www.abed.org.br/censoead2013/CENSO_EAD_2013_PORTUGUES.pdf - Cursos autorizados refere-se à apenas cursos autorizados/reconhecidos por órgão legal(MEC, CNE ou CEE).(2011, p. 10), aqueles que são oferecidos por instituições credenciadas ou autorizados/regulamentados por órgão federal, estadual ou municipal, que exigem presencialidade apenas para fins de avaliação de aprendizagem.
} 
Para se estudar o tema evasão em cursos a distância foram escolhidos uma universidade e um curso: a Universidade de Brasília (UnB) foi selecionada por ser pioneira na oferta de EAD e contar com uma história consistente de oferta de cursos a distância; e o curso de Licenciatura em Música da UnB foi escolhido por apresentar um elevado índice de evasão. De acordo com Ribeiro e Araujo (2012) entre os cursos ofertados por meio do sistema Universidade Aberta do Brasil (UAB) na UnB, o curso de Música apresenta o segundo maior percentual de evasão.

A UnB oferta cursos por meio da modalidade de educação a distância desde 1972, em vários níveis de formação. Atualmente desenvolve um trabalho em parceria com o MEC, CAPES e governos estaduais e municipais na oferta dos cursos vinculados ao Sistema Universidade Aberta do Brasil (UAB). Entre os vários cursos ofertados, está o Curso de Licenciatura em Música.

O Curso de Licenciatura em Música a Distância está em sua $4^{\underline{a}}$ oferta e apresenta um alto índice de evasão ao longo de sua história.

Com base no Sistema de Informações Acadêmicas de Graduação (SIGRA) da UnB, a tabela 1 apresenta o percentual de evasão dos alunos do curso de Licenciatura em Música da UnB.

Tabela 1: Dados da evasão do Curso de Música a Distância da UnB.

\begin{tabular}{|c|c|c|}
\hline & $\begin{array}{l}\text { Alunos } \\
\text { Evadidos }\end{array}$ & $\begin{array}{l}\text { Percentual de } \\
\text { Evasão }\end{array}$ \\
\hline $\begin{array}{c}\text { Turma UAB1 - } \\
2007\end{array}$ & 75 & $82 \%$ \\
\hline $\begin{array}{c}\text { Turma UAB2 - } \\
2009\end{array}$ & 98 & $62 \%$ \\
\hline $\begin{array}{c}\text { Turma UAB3 - } \\
2011\end{array}$ & 53 & $54 \%$ \\
\hline Total de Alunos & 193 & \\
\hline Média de Evasão & & $66 \%$ \\
\hline
\end{tabular}

Fonte: SIGRA-UnB. Outubro/2014

A primeira turma iniciada em 2007 apresentou uma evasão de $82 \%$ dos alunos, a segunda turma iniciada em 2009 apresentou 62\% de evasão e a terceira que iniciou suas atividades em 2011 e ainda está curso, apresenta 54\% de evasão; a quarta turma iniciou suas atividades no 1\%/2014 e por ter iniciado suas atividades após o inicio da pesquisa, que data de outubro de 2012, a evasão desta turma não será estudada; os dados de evasão da UAB4 não serão tratados neste trabalho, não farão parte da pesquisa. $O$ nome dado às turmas serve para facilitar a identificação 
das mesmas. São eles: UAB1 para a primeira turma, UAB2 para a segunda, UAB3 para a terceira e UAB4 para a quarta.

A amostra escolhida para ser pesquisada foi a dos alunos evadidos da $3^{\text {a }}$ turma do curso, denominada UAB3, porque os dados de e-mail e telefone estão mais recentes e o currículo do curso já passou por algumas modificações representando o formato atual do curso, por esses motivos não foram considerados os alunos das demais turmas.

O Curso de Licenciatura em Música a Distância no Brasil é ofertado por apenas três Universidades entre às Instituições Públicas de Ensino Superior, são elas: Universidade Federal do Rio Grande do Sul, Universidade Federal de São Carlos e Universidade de Brasília.

A Universidade de Brasília junto ao programa UAB oferece um curso gratuito e reconhecido pelo Ministério da Educação (MEC), que teve sua 1ª oferta em 2007. A tabela 1, a seguir, apresenta os dados das vagas ofertadas nos quatro vestibulares, quantidade de alunos ingressantes, formados, ativos e alunos evadidos do Curso de Licenciatura em Música a Distância da UnB.

Tabela 2: Dados quantitativos dos alunos do Curso de Música a Distância da UnB.

\begin{tabular}{llrrrr}
\hline & $\begin{array}{l}\text { Oferta de } \\
\text { Vagas no } \\
\text { Vestibular }\end{array}$ & $\begin{array}{l}\text { Alunos } \\
\text { Ingressantes }\end{array}$ & $\begin{array}{l}\text { llunos } \\
\text { Formados }\end{array}$ & $\begin{array}{l}\text { Alunos } \\
\text { Ativos }\end{array}$ & $\begin{array}{l}\text { Alunos } \\
\text { Evadidos }\end{array}$ \\
\hline Turma UAB1 - 2007 & 120 & 92 & 16 & 1 & 75 \\
Turma UAB2 - 2009 & 170 & 158 & 38 & 22 & 98 \\
Turma UAB3 - 2011 & 100 & 99 & 0 & 46 & 53 \\
Turma UAB4 - 2014 & 125 & 124 & 0 & 124 & 0 \\
TOTAL & $\mathbf{5 1 5}$ & $\mathbf{4 7 3}$ & $\mathbf{5 4}$ & $\mathbf{1 9 3}$ & $\mathbf{2 2 6}$ \\
\hline
\end{tabular}

Fonte: SIGRA. OUTUBRO/2014

A $1^{\text {a }}$ oferta data de 2007 e contou com o ingresso de 92 alunos, em 2009 entraram 135, em 2011 ingressaram 84 alunos e em 2014 entraram 124 alunos. Foram ofertadas 515 vagas, preenchidas 473 , destas vagas 54 alunos formaram, 193 estão em curso e 226 evadiram.

Walter (2006) apresenta que a evasão em cursos a distância está sendo investigada com foco na retenção dos alunos. Muito se procura as causas, fatores que levam os alunos da educação a distância a desistirem de seus cursos e a resolução desse problema, contudo, mais que investigar a evasão as pesquisas procuram identificar os fatores, encontrar as motivações para que os alunos 
permaneçam e avançam seus estudos buscando respostas de forma quantitativa e qualitativa para conseguir mapear o esvaziamento dos cursos.

Moore (2008) trata a evasão ou índice de desistência com o olhar sobre os fatores que afetam o sucesso e o fracasso dos alunos, apontando que uma das dificuldades de identificação das causas é o fato de que geralmente a desistência ocorre por um acúmulo de fatores e não somente de um único motivo.

No intuito de colaborar com a discussão a respeito da evasão em cursos a distância, este trabalho apresenta uma pesquisa sobre a evasão do Curso de Licenciatura em Música a Distância da Universidade de Brasília com a intenção de identificar e analisar os fatores que causam evasão dos alunos do curso de Licenciatura em Música a Distância da UnB objetivando dessa forma contribuir com melhorias para o contínuo desenvolvimento do ensino de música a distância. É importante ressaltar que no Brasil existem trabalhos sobre evasão em cursos a distância, contudo não foi encontrado nenhum estudo específico sobre evasão em cursos de Música a distância, fato que ressalta a relevância do presente estudo.

A motivação para o desenvolvimento do presente trabalho veio do não entendimento sobre os motivos que levam os alunos do curso a desistirem da conclusão. O curso de Licenciatura em Música a distância da UnB possibilita que estudantes tenham acesso a uma formação que não é ofertada por outras instituições na maioria das cidades atendidas, sendo assim, os estudantes tiveram oportunidade de ter uma formação reconhecida e mesmo assim desistiram.

O mercado de trabalho para a área de profissionais do ensino de música iniciou uma tendência de melhoria desde 2008 quando foi aprovada a Lei №11.769/2008 de 18 de agosto de 2008 que dispõe sobre a obrigatoriedade do ensino de música como componente curricular obrigatório na educação básica, aumentando a demanda por profissionais formados na área de música. Ao comparar a oferta do curso de Licenciatura em Música $^{2}$ à oferta de outras licenciaturas a distância no Brasil, como Letras ${ }^{3}$, por exemplo, verificar-se-á que há pouca oferta de

\footnotetext{
2 http://www.uab.capes.gov.br/index.php?option=com_wrapper\&view=wrapper\&Itemid=12 - Lista de 2 Licenciaturas em Música ofertadas através do Sistema Universidade Aberta do Brasil. Acessado em $13 \mathrm{dez} / 2013$.

${ }^{3}$ http://www.uab.capes.gov.br/index.php?option=com_wrapper\&view=wrapper\&ltemid=12 - Lista de 39 Licenciaturas em Letras ofertadas através do Sistema Universidade Aberta do Brasil. Acessado em $13 \mathrm{dez} / 2013$.
} 
vagas em cursos de Licenciatura em Música na modalidade a distância nas universidades públicas e mesmo com a necessidade de profissionais capacitados para a docência na área de música a taxa de evasão do curso é alta. O que estaria acontecendo para que os alunos desistissem do curso?

Pretende-se, ao investigar os fatores da evasão neste curso, contribuir para reflexão a respeito da dinâmica de oferta de um curso de música a distância e sobre a oferta deste na UnB.

Será considerado evadido nesta pesquisa o aluno que se matriculou, iniciou o curso e teve seu vínculo cortado de acordo com as regras da Universidade de Brasília. Dentro da nomenclatura utilizada pela UnB, o Curso de Licenciatura em Música a Distância da Universidade de Brasília utiliza como forma de quebra de vínculo com os alunos os itens:

1. Desligamento por abandono de curso;

2. Desligamento por jubilamento;

3. Desligamento por não-cumprimento de condição;

4. Desligamento voluntário;

5. Transferência para outras Instituições de Ensino Superior. ${ }^{4}$

Esta pesquisa foi desenvolvida tendo como apoio a metodologia quantitativa. Sendo uma pesquisa exploratória e descritiva sobre o universo da evasão em cursos de Música a Distância, com foco na terceira oferta do Curso de Licenciatura em Música a Distância da Universidade de Brasília. Como instrumento de coleta de dados utilizou um questionário aplicado via ligações telefônicas e e-mail. A terceira turma foi escolhida como amostra por contar com um percentual elevado de evasão, de $64 \%$, e porque foi mais propício o estabelecimento do contato com os alunos evadidos em função dos dados de telefone e e-mail serem mais recentes.

Apoiado na literatura foi construído um questionário e submetido aos alunos evadidos do curso via ligações telefônicas e e-mail. Acredita-se que o resultado da pesquisa possibilitará a compreensão dos aspectos mais relevantes que influenciam a evasão do curso de Licenciatura em Música a distância da UnB e a partir desses resultados dará subsídios para diminuir os índices de evasão do curso em suas próximas ofertas, atendendo à meta do curso "de formar professores de música com qualidade musical e pedagógica." (Marins e Narita, 2012, p.158)

\footnotetext{
${ }^{4}$ A descrição destes itens encontra-se no capítulo II, item 2.3.
} 
O objetivo geral desta pesquisa foi identificar e analisar os fatores que causam evasão dos alunos do curso de Licenciatura em Música a Distância da UnB. Como objetivos específicos, procurou-se conhecer o perfil do aluno que abandona o curso e identificar se há relação entre a especificidade do curso de música e a evasão.

Esta dissertação está estruturada em cinco capítulos que abordam questões ligadas aos seguintes temas: EAD; Universidade Aberta do Brasil; Universidade de Brasília; Ensino de Música a Distância; Evasão de Cursos a Distância; Evasão de Curso de Música a Distância; e Curso de Licenciatura em Música a Distância da Universidade de Brasília.

O Capítulo 1, intitulado Contexto Histórico do Sistema Universidade Aberta do Brasil na UnB tem por objetivo contextualizar o Sistema Universidade Aberta do Brasil na UnB e sua implantação dentro do Departamento de Música da UnB. É importante conhecer o contexto histórico do curso para se entender os fatos.

O Capítulo 2, intitulado Evasão, estuda a etimologia da palavra evasão e a conceituação do fenômeno, apresenta os dados de evasão do Curso de Licenciatura em Música a Distância da UnB e procura entender como a UnB define evasão.

O Capítulo 3 apresenta a metodologia utilizada na pesquisa. Esclarece a escolha do método, da amostragem e do instrumento.

O Capítulo 4 trata da análise dos dados e o Capítulo 5 apresenta as considerações finais a cerca da pesquisa e do trabalho.

Este trabalho se propõe a buscar novos conhecimentos sobre a evasão em cursos de música a distância com a finalidade de contribuir para com a discussão de problemas relacionados a essa modalidade educativa.

De acordo com Ribeiro e Araujo (2012), entre os cursos ofertados por meio do sistema UAB na UnB, o curso de Licenciatura em Música apresenta o segundo maior percentual de evasão. Portanto, se há a necessidade de profissionais formados, há demanda de professores na rede pública e privada, há políticas de democratização desse ensino e o curso de Música da UnB foi reconhecido pela CAPES $^{5}$ com nota 3 no Exame Nacional de Desempenho de Estudantes (ENADE), porque esses alunos estão evadindo?

\footnotetext{
5 http://www.capes.gov.br/sobre-a-capes/historia-e-missao Acesso em 26/08/2013. CAPES Coordenação de Aperfeiçoamento de Pessoal de Nível Superior, entre outras atribuições é responsável pelo Sistema Universidade Aberta do Brasil.
} 


\section{CAPÍTULO 1 - HISTÓRIO DO SISTEMA UNIVERSIDADE ABERTA DO BRASIL NA UNIVERSIDADE DE BRASÍLIA E EM SEU DEPARTAMENTO DE MÚSICA}

O Capítulo I busca apresentar como foi estruturado o Sistema Universidade Aberta do Brasil e como o sistema foi implantado no Departamento de Música da UnB. É relevante conhecer essa história para entender o processo de estruturação do curso de Música a Distância dessa universidade.

\subsection{Histórico do Sistema Universidade Aberta do Brasil}

A Universidade Aberta do Brasil (UAB) é um sistema do Governo Federal que foi criado em 2005, com o intuito de contribuir com a expansão das vagas de graduação nas universidades públicas brasileiras.

As iniciativas de alguns parlamentares brasileiros em implantar a Universidade Aberta no Brasil começaram em 1972, mas, segundo Alves (2009), foram tentativas sem sucesso. Foi retomada a questão em meados de 2005, por iniciativa do poder executivo de criar um novo sistema. Criou-se um consórcio de instituições públicas de ensino superior, denominado Universidade Aberta do Brasil. "Na verdade, não é uma universidade propriamente dita, mas, sim um consórcio de instituições públicas de ensino superior. Além disso, também não é aberta, uma vez que não possui os princípios norteadores desse sistema." (ALVES, 2009, p.12)

O Sistema Universidade Aberta do Brasil - UAB foi instituído pelo Decreto № 5.800 de 6 de junho de 2006, tendo em vista a atender o Art. 80 e 81 da Lei № 9394 - Lei de Diretrizes e Bases da Educação Nacional. De acordo com o Artigo 1ำ desse decreto, o Sistema UAB é "voltado para o desenvolvimento da modalidade de educação a distância, com a finalidade de expandir e interiorizar a oferta de cursos e programas de educação superior no País." (Decreto № 5.800) O Sistema UAB apresenta como objetivos:

I - oferecer, prioritariamente, cursos de licenciatura e de formação inicial e continuada de professores da educação básica;

II - oferecer cursos superiores para capacitação de dirigentes, gestores e trabalhadores em educação básica dos Estados, do Distrito Federal e dos Municípios;

III - oferecer cursos superiores nas diferentes áreas do conhecimento;

IV - ampliar o acesso à educação superior pública;

$\checkmark$ - reduzir as desigualdades de oferta de ensino superior entre as diferentes regiões do País;

VI - estabelecer amplo sistema nacional de educação superior a distância; e 
VII - fomentar o desenvolvimento institucional para a modalidade de educação a distância, bem como a pesquisa em metodologias inovadoras de ensino superior apoiadas em tecnologias de informação e comunicação.( Decreto $n^{\circ} 5.800$ de 6 de junho de 2006, Art. $1^{\circ}$ )

Observa-se que a UAB foi planejada para atender a alguns objetivos e metas do Plano Nacional de Educação (PNE) 2001-2011, tais como:

Estabelecer uma política de expansão que diminua as desigualdades e oferta existentes entre as diferentes regiões do País. *

Estabelecer um amplo sistema interativo de educação a distância, utilizando-o, inclusive, para ampliar as possibilidades de atendimento nos cursos presenciais, regulares ou de educação continuada. **(LEI №10172, PLANO NACIONAL DE EDUCAÇÃO, 4.3-OBJETIVOS E METAS, 2001, p.37)

A modalidade de ensino adotada pela UAB é de Educação a Distância, em que se utiliza um Ambiente Virtual de Aprendizagem (AVA), chamado Modular Object-Oriented Dynamic Learning Environment (Moodle), para ministrar as aulas. A metodologia é semipresencial, na qual as atividades são divididas em presenciais e a distância. O Decreto no 5.622 determina que os alunos tenham periodicamente encontros presenciais no polo ao qual é vinculado e que a maior parte das atividades avaliativas seja desenvolvida no polo de apoio presencial.

\&1ำ A educação a distância organiza-se segundo metodologia, gestão e avaliação peculiares, para as quais deverá estar prevista a obrigatoriedade de momentos presenciais para:

I - avaliação de estudantes;

II - estágios obrigatórios, quando previstos na legislação pertinente;

III - defesa de trabalhos de conclusão, quando previstos na legislação pertinente; e

IV - atividades relacionadas a laboratórios de ensino, quando for 0 caso.(DECRETO № 5.622, DE 19 DE DEZEMBRO DE 2005)

Para cumprir as finalidades e objetivos sócio educacionais do Sistema Universidade Aberta do Brasil o Ministério da Educação estruturou a UAB envolvendo instituições públicas de ensino superior e entes federativos - municípios, estados e distrito federal.

O MEC propôs às instituições públicas de ensino superior convênios nos quais elas fariam oferta de cursos e programas de educação superior a distância. Para os entes federativos, foi proposto um acordo de cooperação técnica ou convênios em que estes entes manteriam polos de apoio presencial.

De acordo com Decreto № 5.800 o sistema procurou integrar os entes federativos com as instituições públicas de ensino superior seguinte forma:

- Ministério da Educação - institui, monitora e avalia institucionalmente; 
"as despesas do Sistema UAB correrão à conta das dotações orçamentárias anualmente consignadas ao Ministério da Educação e ao Fundo Nacional de Desenvolvimento da Educação - FNDE." (Decreto № 5.800, Art. 6º)

- Instituições públicas de ensino superior - corpo docente; gestão acadêmica e financeira dos cursos.

- Entes federativos - geram demanda de cursos e subsidiam o polo de apoio presencial

caracteriza-se o polo de apoio presencial como unidade operacional para o desenvolvimento descentralizado de atividades pedagógicas e administrativas relativas aos cursos e programas ofertados a distância pelas instituições públicas de ensino superior.(DECRETO №5.800, ART. $2^{\circ}$, $§ 1^{\circ}$ )

A Portaria Normativa № 2, de 10 de janeiro de 2007 "que dispõe sobre os procedimentos de regulação e avaliação da educação superior na modalidade a distância", estabelece no artigo $2^{\circ}$, parágrafo $1^{\circ}$ e $2^{\circ}$ que:

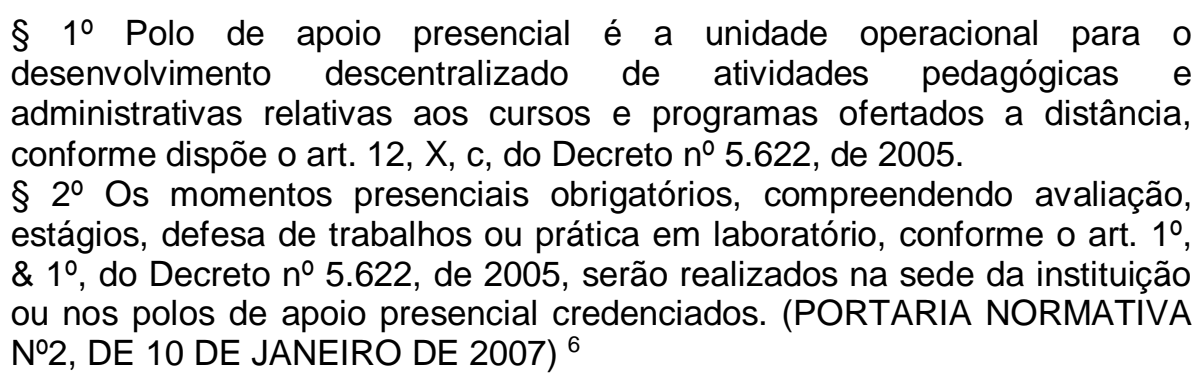

A UAB tem como característica expandir e interiorizar a oferta de cursos e programas de ensino superior. A possibilidade de se ter uma educação superior e continuada mesmo longe dos grandes centros é um avanço para o desenvolvimento da educação no Brasil e consequentemente da população.

No Histórico da UAB, apresentado no site da Capes $^{7}$, se encontram expostos os cinco eixos fundamentais do sistema. São eles:

O Sistema UAB sustenta-se em cinco eixos fundamentais:

- Expansão pública da educação superior, considerando os processos de democratização e acesso;

6 PORTARIA NORMATIVA No 2 , DE $10 \quad$ DE $\quad$ JANEIRO $\quad$ DE $2007 \quad-$ http://www.uab.capes.gov.br/images/stories/downloads/legislacao/portaria_normativa_22007.pdf - Acessado em 06.05 .2014 .

\footnotetext{
${ }^{7}$ Histórico da UAB http://uab.capes.gov.br/index.php?option=com_content\&view=article\&id=9\&Itemid=21 Acessado em 05/02/2013
} 
- Aperfeiçoamento dos processos de gestão das instituições de ensino superior, possibilitando sua expansão em consonância com as propostas educacionais dos estados e municípios;

- Avaliação da educação superior a distância tendo por base os processos de flexibilização e regulação implantados pelo MEC;

- Estímulo à investigação em educação superior a distância no País;

- Financiamento dos processos de implantação, execução e formação de recursos humanos em educação superior a distância.(PORTARIA NORMATIVA No2, DE 10 DE JANEIRO DE 2007)

$\bullet$

Os dados de histórico encontrados no site da Capes ${ }^{8}$, com data de 2010, afirma que:

\begin{abstract}
Atualmente, 88 instituições integram o Sistema UAB, entre universidades federais, universidades estaduais e Institutos Federais de Educação, Ciência e Tecnologia (IFETs). De 2007 a julho de 2009, foram aprovados e instalados 557 polos de apoio presencial com 187.154 vagas criadas. A UAB, ademais, em agosto de 2009, selecionou mais 163 novos polos, no âmbito do Plano de Ações Articuladas, para equacionar a demanda e a oferta de formação de professores na rede pública da educação básica, ampliando a rede para um total de 720 polos. Para 2010, espera-se a criação de cerca de 200 polos.
\end{abstract}

De acordo com a Capes, atualmente, são ofertados pela UAB cursos de:

- Bacharelados, Licenciaturas, Tecnólogo e Especializações;

- Especializações do programa Mídias na Educação;

- Graduação em Biblioteconomia;

- Especializações para professores, em parceria com a Secretaria de Educação Continuada, Alfabetização e Diversidade (SECAD/MEC); e

- Programa Nacional de Formação em Administração Pública - PNAP.

Os cursos do Sistema UAB são gratuitos, à distância e ofertados por instituições públicas de ensino superior. Estas instituições têm autonomia sobre a forma de seleção de seus alunos, o processo seletivo pode acontecer por meio de vestibular e ENEM. Das vagas ofertadas, todos os cursos têm vagas destinadas ao público em geral e os cursos de Licenciatura podem fazer reserva de vagas para professores de educação das redes públicas, estadual ou municipal.

\title{
1.2 Implantação do Sistema Universidade Aberta do Brasil na UnB
}

A "Universidade de Brasília é pioneira na oferta de cursos a distância no ensino superior brasileiro. O seu projeto original já preconizava em 1961, o emprego

\footnotetext{
${ }^{8}$ Histórico da UAB http://www.uab.capes.gov.br/index.php?option=com_content\&view=article\&id=9:historico\&catid=6:sobre\&Itemid=21 Acessado em 05/02/2013.
} 
das tecnologias na educação, de forma democrática e criativa." (PEREIRA E MORAES, 2009, p. 83).

A Universidade de Brasília (UnB) iniciou suas atividades na área de EAD a partir da década de 1970 e procurou manter sua proposta de diversificar a forma de ensino no ensino superior brasileiro.

De acordo com Pontes (2009), a Faculdade de Educação teve a iniciativa de, em 1975, criar a habilitação em Tecnologia Educacional no curso de Pedagogia com o intuito de abrir fronteiras na UnB na área das tecnologias educativas.

De acordo com Martins (2006), a UnB assinou um convênio com a Open University, em 26 de janeiro 1979, e a partir de então começou a promover a oferta cursos de extensão na modalidade a distância. Contou com o aval da Reitoria, 0 financiamento da Editora UnB e o uso da metodologia da Universidade Aberta da Inglaterra. Esse convênio vigorou de 1979 a 1985.

O convênio se deu da seguinte forma:

O Convênio assinado em 26 de janeiro de 1979 previa a reprodução de materiais didáticos de alto padrão, traduzidos pela editora da UnB e distribuídos comercialmente em todo o país. A Editora da Universidade teria a first option, ou seja, a primeira opção para edição da obra em português; não havendo interesse da UnB, o direito de publicação da obra seria repassado a outras editoras do mercado para publicação no Brasil. Parte do valor de venda dos títulos traduzidos e publicados pela Editora da UnB, à medida que fossem sendo comercializados, retornaria para a Open sob a forma de direitos autorais. A Open cederia, porém, os direitos de uso acadêmico de seus materiais educacionais para a UnB, sem o pagamento de royalties.(MARTINS, 2006, p. 74)

Esse convênio possibilitou um trabalho em conjunto entre a Open University e a UnB, representada pelo Decanato de Extensão (DEX) e a Editora UnB.

A UnB na década de 80 teve uma importante contribuição na área de educação a distância, segundo Martins. No quadro 1 a seguir será apresentada uma linha do tempo da história da EAD na UnB, na referida década. 
Quadro 1: EAD na UnB na década de 1980.

\begin{tabular}{|c|c|c|}
\hline Ano & Curso & Descrição \\
\hline \multirow[t]{3}{*}{1980} & $\begin{array}{ll}\text { Programa } & \text { Ensino } \\
\text { Distância(PED) } & \end{array}$ & $\begin{array}{l}\text { Curso de extensão chamado Curso } \\
\text { de Introdução à Ciência Política }\end{array}$ \\
\hline & $\begin{array}{l}\text { Seminários e conferências } \\
\text { Publicações: } \\
\text { "Cadernos da UnB" } \\
\text { "Encontros da UnB" }\end{array}$ & $\begin{array}{l}\text { Discussão de política nacional e } \\
\text { internacional }\end{array}$ \\
\hline & Atividades diversificadas & $\begin{array}{l}\text { Atividades diversificadas com } \\
\text { Departamentos e Institutos tanto } \\
\text { das áreas de Ciências Exatas } \\
\text { quanto de Humanidades }\end{array}$ \\
\hline \multirow[t]{2}{*}{1981} & $\begin{array}{l}\text { Continuidade das atividades de } \\
\text { extensão }\end{array}$ & $\begin{array}{l}\text { Continuidade na discussão de } \\
\text { temas de interesse internacional }\end{array}$ \\
\hline & $\begin{array}{llll}\text { Programa na } & \text { TV } & \text { Nacional } \\
\text { (RADIOBRAS) } & & \end{array}$ & $\begin{array}{l}\text { Intitulado "Universidade Aberta" e } \\
\text { transmitido para todo o Brasil, } \\
\text { objetivava o debate e análise de } \\
\text { temas culturais e políticos de } \\
\text { importância no momento. }\end{array}$ \\
\hline 1982 & Cursos diversos & $\begin{array}{l}\text { Cursos veiculados no Jornal de } \\
\text { Brasília, O Globo e outros veículos } \\
\text { de comunicação }\end{array}$ \\
\hline 1983 & $\begin{array}{lll}\text { Cursos sobre o tema } \\
\text { Universidade Aberta }\end{array}$ & $\begin{array}{l}\text { Em forma de encartes, trabalhou } \\
\text { com diversos jornais como Jornal } \\
\text { da Tarde, Zero Hora, O } \\
\text { Fluminense, Tribuna do Norte, O } \\
\text { Globo e a Revista Ciência }\end{array}$ \\
\hline 1986 & $\begin{array}{l}\text { Criação do Centro de Produção } \\
\text { Cultural e Educativa - CPCE }\end{array}$ & $\begin{array}{l}\text { Executar projetos na área de } \\
\text { audiovisuais, promover a educação } \\
\text { e a cultura por meio de multimeios }\end{array}$ \\
\hline 1988 & $\begin{array}{l}\text { Criação do Centro de Educação } \\
\text { a Distância - CEAD }\end{array}$ & $\begin{array}{l}\text { Criação da Rede Brasileira de } \\
\text { Educação Superior Aberta e a } \\
\text { Distância }\end{array}$ \\
\hline
\end{tabular}


Segundo Pontes (2009), em 1994, foi implantado na FE-UnB o Consórcio Interuniversitário de Educação Continuada e a Distância - BRASILEAD. Pereira e Moraes (2009) divergem um pouco na nomenclatura e definem o BRASILEAD como Consórcio Brasileiro de Educação a Distância, que, em 1994, congregou um número significativo de universidades públicas brasileiras e foi considerado pela referida autora como embrião da Universidade Virtual Pública do Brasil-UNIREDE e Universidade Aberta do Brasil-UAB.

Em 1996, a Faculdade de Educação da UnB começou a ofertar o Curso de Especialização em Educação Continuada e a Distância, que contou com o apoio da Cátedra Unesco de Educação a Distância e do Ministério de Educação. A UnB participou das 5 gerações de modelos de EAD que serão apresentadas no quadro 2. 


\section{Quadro 2. Modelos de educação a distância - Estrutura conceitual}

\begin{tabular}{|c|c|c|c|c|c|c|}
\hline \multirow{3}{*}{$\begin{array}{c}\text { Modelos de Educação a Distância } \\
\text { e Tecnologias de Distribuição } \\
\text { Associadas }\end{array}$} & \multicolumn{6}{|c|}{ Características das Tecnologias de Distribuição } \\
\hline & \multicolumn{3}{|c|}{ Flexibilidade } & \multirow{2}{*}{$\begin{array}{l}\text { Materiais } \\
\text { Altamente } \\
\text { Refinados }\end{array}$} & \multirow{2}{*}{$\begin{array}{l}\text { Distribuição } \\
\text { Interativa } \\
\text { Avançada }\end{array}$} & \multirow{2}{*}{$\begin{array}{c}\text { Custos } \\
\text { Institucionais } \\
\text { Variáveis } \\
\text { Zero }\end{array}$} \\
\hline & Tempo & Local & Ritmo & & & \\
\hline $\begin{array}{l}1 \text { Geração } \\
\text { Modelos por Correspondência } \\
\text { - Impresso }\end{array}$ & Sim & Sim & Sim & Sim & Năo & Nấo \\
\hline $\begin{array}{ll}2 \text { Geração } \\
\text { Modelo Multimídia } \\
\text { - } & \text { Impresso } \\
\text { - } & \text { Rádio } \\
\text { - } & \text { Vídeo } \\
\text { - } & \text { Computador baseado no } \\
& \text { ensino } \\
\text { - } & \text { (CML/CAL/IMM) } \\
\text { - } & \text { Vídeo interativo }\end{array}$ & $\begin{array}{l}\text { Sim } \\
\text { Sim } \\
\text { Sim } \\
\text { Sim } \\
\text { Sim }\end{array}$ & $\begin{array}{l}\text { Sim } \\
\text { Sim } \\
\text { Sim } \\
\text { Sim } \\
\text { Sim }\end{array}$ & $\begin{array}{l}\text { Sim } \\
\text { Sim } \\
\text { Sim } \\
\text { Sim } \\
\text { Sim }\end{array}$ & $\begin{array}{l}\text { Sim } \\
\text { Sim } \\
\text { Sim } \\
\text { Sim } \\
\text { Sim }\end{array}$ & $\begin{array}{l}\text { Nấo } \\
\text { Nấo } \\
\text { Nấo } \\
\text { Sim } \\
\text { Sim }\end{array}$ & $\begin{array}{l}\text { Năo } \\
\text { Năo } \\
\text { Năo } \\
\text { Năo } \\
\text { Năo }\end{array}$ \\
\hline
\end{tabular}

\section{Geração}

Modelo de Aprendizagem por

Conferência

- Áudio-teleconferência

- Videoconferência

- Comunicação áudio gráfica

- TV/Rádio e Áudio-conferência

\begin{tabular}{|c|c|c|c|c|}
\hline Nắo & Năo & Năo & Năo & Sim \\
\hline Nắo & Não & Nấo & Năo & Sim \\
\hline Nắo & Năo & Năo & Sim & Sim \\
\hline Não & Não & Năo & $\mathrm{Sim}$ & Sim \\
\hline
\end{tabular}

\section{Geração}

Modelo de Aprendizagem Flexível

- Multimídia interativa (MM) on-line

- Internet baseada no acesso ao recurso WWW

- Comunicação Mediada por computador

\section{Geração}

Modelo de Aprendizagem Flexível

- Inteligente

- Multimídia interativa on-line

- Internet - recursos WWW

- Computador usando sistema de respostas automáticas

- Acesso ao portal do campus para processos e recursos

\begin{tabular}{l|l|l|l|l|l} 
Sim & Sim & Sim & Sim & Sim & Sim \\
Sim & Sim & Sim & Sim & Sim & Sim \\
Sim & Sim & Sim & Sim & Sim & Não
\end{tabular}

Fonte: James C. Taylor. Fifth Generation Distance Education, 2001, p. 3, apud PEREIRA, 2003, p. 208. 
Atualmente a UnB conta com várias iniciativas de EAD: oferta cursos de extensão, aperfeiçoamento, graduação, pós-graduação por meio de seus departamentos, institutos, faculdades; Interfoco (Unidade responsável pela oferta de parte dos cursos de extensão); Centro de Educação a Distância; Programa Universidade Aberta do Brasil, além de estar passando pelo processo de institucionalização da EAD.

As atividades relacionadas à implantação da UAB na UnB tiveram início no ano de 2005 quando a UnB participou do $1^{\circ}$ edital de $\mathrm{UAB}^{9}$ denominado edital de UAB1. Ao MEC foram apresentados 11 projetos de cursos de graduação, pósgraduação (lato sensu) e extensão. Em resposta aos projetos apresentados, a UnB teve seis projetos aprovados para o provimento de cursos de graduação em nível de Licenciatura em Artes Visuais, Música, Teatro, Letras/Português, Pedagogia e Educação Física.

De acordo com informações constantes no portal da EAD na UnB

Em 2006, por meio do Programa UAB a UnB iniciou a oferta do curso de Administração pela Faculdade de Economia, Administração, Contabilidade, Ciência da Informação e Documentação (FACE), em um projeto intitulado Piloto, que previa o convênio com o Banco do Brasil.

No Projeto Piloto do curso de Administração a distância, a UnB participou do consórcio nacional abrindo vagas para a região Centro-Oeste e Norte. $\mathrm{Na}$ sequência das ações de implementação de políticas educacionais, em 2006, a Faculdade de Educação estabeleceu parceria com a Secretaria de Estado de Educação do Acre para a oferta do curso de Pedagogia, destinado à formação de 800 professores da escola pública básica daquele Estado (curso em andamento). (http://www.ead.unb.br/index.php/linha-dotempo)

O primeiro vestibular para provimento das vagas aprovadas no edital de UAB1 aconteceu no final de 2007. Foram oferecidas 1.080 vagas às cidades de seis estados brasileiros. A saber: Acre; Goiás; São Paulo; Bahia; Alagoas; e Paraíba. Contou com o ingresso de 940 alunos. O curso de Licenciatura em Música a Distância da UnB ofertou 120 vagas destas 940.

Em 2009, aconteceu o segundo vestibular da UAB na UnB atendendo ao edital UAB2. Foram ofertados os seis cursos em vigor e teve o acréscimo de dois novos cursos de graduação, Licenciaturas em Geografia e Biologia. O Curso de Licenciatura em Música a Distância na ocasião ofertou 170 vagas.

\footnotetext{
${ }^{9}$ Edital de UAB1 -

$<h t t p: / / w w w . u a b . c a p e s . g o v . b r / i n d e x . p h p ? o p t i o n=c o m \_c o n t e n t \& v i e w=a r t i c l e \& i d=11 \& l t e m i d=24>$
} 
Em 2009 foram criados os cursos de Especialização em Desenvolvimento Humano, Educação e Inclusão Escolar; Especialização em Educação de Jovens e Adultos na Diversidade e Cidadania. Esses cursos de especialização são frutos de uma parceria entre o Programa de Pós-Graduação em Educação da Faculdade de Educação (FE), o Programa de Pós-Graduação do Instituto de Psicologia (IP), e o Núcleo da Universidade Aberta do Brasil da Universidade de Brasília - UAB/UnB. Esse núcleo sofreu algumas modificações devido à gestão da universidade e atualmente se chama Diretoria de Ensino de Graduação a Distância.

Em 2011, a UnB promoveu o $3^{\circ}$ vestibular direcionado à oferta de cursos por meio do sistema $U A B$ atendendo a uma dinâmica bienal de vestibulares para as licenciaturas. Mantiveram-se os mesmos cursos. Neste vestibular foram ofertadas 1.105 vagas. Para o curso de Licenciatura em Música a Distância da UnB foram destinadas 100 vagas e em 2013 foram oferecidas 1.410 vagas pelo sistema UAB na UnB, destas 125 foram destinadas ao curso de Licenciatura em Música a Distância.

\subsection{Histórico do Curso de Licenciatura em Música a Distância da Universidade de Brasília}

O Curso de Licenciatura em Música a Distância da UnB iniciou suas atividades em $2007^{10}$. Os gestores da modalidade, dentro do Departamento de Música (MUS) da Universidade de Brasília, interessaram-se pelo projeto e submeteram uma proposta ao $1^{\circ}$ edital direcionado às licenciaturas no qual obtiveram sucesso. Em 31 de maio de 2007, o curso teve sua aprovação dentro da 413 ${ }^{\text {a }}$ Reunião do Conselho de Ensino, Pesquisa e Extensão e em 15 de junho de 2007 foi aprovado na 329르 Reunião Ordinária do Conselho Universitário.

Uma iniciativa muito ousada no Brasil, pois é incomum a oferta de graduação a distância na área de Música em instituições públicas. Em virtude dessa demanda, - Grupo de Educação Musical (GEM) do Departamento de Música assumiu as atividades da implantação da UAB.

10 A linha do tempo abordada nesta parte do texto segue a linha apresentada por Marins e Narita(2012) no artigo Licenciatura em Música a Distância na UnB: planejamento e implementação. 
De acordo com Marins e Narita:

"O Projeto Político Pedagógico-PPP desse curso foi elaborado pelo GEM, escrito em consonância com as Diretrizes Curriculares Nacionais para os Cursos de Graduação em Música e com outros atos do Conselho Nacional de Educação-CNE que normatizam os cursos de licenciatura, de graduação plena e de formação de professores de educação básica em nível superior. Também foram observados os Referenciais de Qualidade para Cursos a Distância, elaborados pela Secretaria de Educação a Distância do Ministério de Educação, enfatizando a formação para o uso didático de tecnologias de informação e comunicação-TICs."(MARINS e NARITA, 2012, p.152)

O primeiro processo seletivo aconteceu em 2007. A prova escrita do vestibular do curso a distância tem o mesmo padrão de provas da modalidade presencial, que é constituída por provas de conhecimentos gerais, redação e habilidades específicas em Música. A prova de habilidades específicas é apenas classificatória para os alunos do curso a distância.

O Centro de Seleção e de Promoção de Eventos (CESPE), que conduz os vestibulares da UnB, executou todos os processos seletivos para entrada no curso de Licenciatura em Música a Distância da UnB. As provas são aplicadas nos polos de apoio presencial. A prova de habilidades específicas é gravada em vídeo pelos fiscais do CESPE e enviada ao MUS para avaliação da banca de professores de Música.

O Curso de Licenciatura em Música a Distância da UnB tem a duração de quatro anos e está em sua quarta oferta. Ele foi iniciado em 2007 seguiu um cronograma de ofertas bienais. A tabela 3 apresenta as turmas, datas dos vestibulares, período de início das aulas, quantidade de vagas disponíveis no vestibular e quantidade de alunos que foram matriculados.

\section{Tabela 3 - Dados dos vestibulares do curso de Licenciatura em Música a Distância da UnB.}

Dados dos Vestibulares do Curso de Licenciatura em Música a Distância da UnB

\begin{tabular}{|ccccc}
\hline Turmas & $\begin{array}{c}\text { Datas dos } \\
\text { Vestibulares }\end{array}$ & $\begin{array}{c}\text { Período de } \\
\text { início das } \\
\text { aulas }\end{array}$ & $\begin{array}{c}\text { Quantidade } \\
\text { de vagas }\end{array}$ & $\begin{array}{c}\text { Quantidade de Alunos } \\
\text { Matriculados }\end{array}$ \\
\hline UAB1 & $05 / 08 / 2007$ & $2^{\circ} / 2007$ & 120 & 92 \\
\hline UAB2 & $18 / 01 / 2009$ & $1 \% / 2009$ & 170 & 158 \\
UAB3 & $18 / 12 / 2010$ & $1 \% / 2011$ & 100 & 99 \\
UAB4 & $07 / 07 / 2013$ & $1 \% / 2014$ & 125 & 124 \\
\hline Total & & & 515 & 473 \\
\hline
\end{tabular}

Fonte: EDITAL № 1 - UnB/UAB, DE 2 DE JULHO DE 2007, EDITAL № 1 - UnB/UAB, DE 28 DE OUTUBRO DE 2008, EDITAL № 1 - UnB/UAB, DE 29 DE SETEMBRO DE 2010, EDITAL № 1 UnB/UAB, DE 22 DE MAIO DE 2013 e SIGRA-UnB, Outubro/2014. 
O curso iniciou sua oferta em 2007, o primeiro vestibular foi aplicado em agosto de 2007, contabilizando 92 alunos matriculados na turma de UAB1. A turma de UAB2 iniciada em 2009, contou com 158 alunos matriculados. A UAB3 com 99 que iniciaram em 2011 e UAB4 com 124 iniciados em 2014.

Totalizando 515 vagas ofertadas e 473 alunos matriculados.

A seguir será apresentada a oferta de vagas dentro do curso.

Tabela 4: Oferta de vagas do $1^{\circ}$ vestibular para o Curso de Licenciatura em Música a Distância da UnB.

\section{Oferta de Vagas do $1^{\circ}$ Vestibular do Curso de Licenciatura em Música a Distância da UnB}

\begin{tabular}{lcccc}
\multicolumn{1}{c}{ Polo } & $\begin{array}{c}\text { Vagas } \\
\text { demanda } \\
\text { social }\end{array}$ & $\begin{array}{c}\text { Vagas para professores } \\
\text { em exercício da rede } \\
\text { pública de ensino }\end{array}$ & $\begin{array}{c}\text { Total de } \\
\text { vagas por } \\
\text { polo }\end{array}$ & $\begin{array}{c}\text { Vagas } \\
\text { preenchidas }\end{array}$ \\
\hline Acrelândia-AC & 7 & 8 & 15 & 7 \\
Brasiléia-AC & 7 & 8 & 15 & 12 \\
\hline Cruzeiro do Sul- & & & & \\
AC & 7 & 8 & 15 & 18 \\
Feijó-AC & 7 & 8 & 15 & 3 \\
Rio Branco-AC & 7 & 8 & 25 & 25 \\
Sena Madureira- & & 8 & 15 & 9 \\
AC & 7 & 8 & 15 & 7 \\
Tarauacá-AC & 7 & 8 & 15 & 11 \\
Xapuri-AC & 7 & 64 & 120 & 92 \\
\hline Total de vagas & 56 & & & \\
\hline
\end{tabular}

\section{Total de vagas}

do vestibular

Total de vagas

do preenchidas

Fonte: EDITAL № 1 - UnB/UAB, DE 2 DE JULHO DE 2007 e SIGRA-UnB, Outubro/2014.

O primeiro edital para o vestibular com data de 2 de julho de 2007 ofertou 120 vagas. Foram preenchidas 92, distribuídas em 8 polos de apoio presencial localizados nas cidades de Acrelândia, Brasiléia, Cruzeiro do Sul, Feijó, Rio Branco, Sena Madureira, Tarauacá e Xapuri, todas do estado do Acre. As vagas foram 
distribuídas para demanda social ${ }^{11}$ e a uma cota destinada aos professores da rede pública (municipal ou estadual) da sede do polo ou municípios circunvizinhos.

A UnB deu prioridade aos professores da rede pública (municipal ou estadual) ofertando em torno de $50 \%$ das vagas abertas nos dois primeiros vestibulares. "São objetivos do Sistema UAB: I - oferecer, prioritariamente, cursos de licenciatura e de formação inicial e continuada de professores da educação básica." (DECRETO 5.800, DE 08 DE JUNHO DE 2006).

Como o total de vagas não foi preenchido em alguns polos, 3 vagas foram remanejadas para o polo de Cruzeiro do Sul.

Foi previsto em edital, no item 2.5, que:

2.5 Não havendo preenchimento das vagas em um determinado curso de um polo de apoio presencial, a critério da coordenação do curso, poderão ser chamados candidatos aprovados no mesmo curso em outros polos, seguindo-se, obrigatoriamente, a classificação geral dos candidatos ao curso. EDITAL № 1 - UnB/UAB, DE 2 DE JULHO DE 2007

De acordo com os dados do SIGRA, no $2^{0}$ semestre de 2014, a primeira turma de alunos do curso de Licenciatura em Música a Distância da UnB, denominada UAB1, apresentava 16 alunos formados, 1 aluno ativo e 75 alunos evadidos. A tabela 5 apresentará dados sobre a oferta de vagas no $2^{\circ}$ vestibular do curso, quais polos, quantidade de vagas para demanda social, quantidade de vagas destinadas a professores em exercício da rede pública de ensino, total de vagas por polo e vagas preenchidas.

\footnotetext{
11 Demanda social - o edital de vestibular apresenta essa nomenclatura para qualquer pessoa que tenha o ensino médio que é requisito e que queira concorrer às vagas.
} 
Tabela 5: Oferta de Vagas do 2ํㅡㄴ Vestibular do Curso de Licenciatura em Música a Distância da UnB

Oferta de Vagas do 2o Vestibular do Curso de Licenciatura em Música a Distância da UnB

\begin{tabular}{lcccc}
\hline \multicolumn{1}{c}{ Polo } & $\begin{array}{c}\text { Vagas } \\
\text { demanda } \\
\text { social }\end{array}$ & $\begin{array}{c}\text { Vagas para } \\
\text { professores em } \\
\text { exercício da rede } \\
\text { pública de ensino }\end{array}$ & $\begin{array}{c}\text { Total de } \\
\text { vagas } \\
\text { por polo }\end{array}$ & $\begin{array}{c}\text { Vagas } \\
\text { preenchidas }\end{array}$ \\
\hline Acrelândia-AC & 12 & 13 & 25 & 7 \\
\hline Anápolis-GO & 10 & 10 & 20 & 3 \\
\hline Brasiléia-AC & 10 & 10 & 20 & 23 \\
\hline Cruzeiro do Sul-AC & 10 & 10 & 20 & 31 \\
\hline Porto Nacional-TO & 12 & 13 & 25 & 9 \\
\hline Posse-GO & 10 & 10 & 20 & 11 \\
\hline Rio Branco-AC & 10 & 10 & 20 & 20 \\
\hline Sena Madureira-AC & 10 & 10 & 20 & 23 \\
\hline Tarauacá-AC & 84 & 86 & 170 & 167 \\
\hline Total de vagas & & & & 170 \\
\hline Total de vagas do vestibular & & & 167 \\
\hline Total de vagas do preenchidas & & & \\
\hline Fonte: EDITAL № 1- UnB/UAB, DE 28 DE OUTUBRO DE 2008 e SIGRA, Outubro/2014.
\end{tabular}

A segunda entrada aconteceu em 2009 e contou com o ingresso de 167 alunos. Nesta oferta 10 polos foram contemplados: um em Tocantins, na cidade de Porto Nacional; dois em Goiás nas cidades de Posse e Anápolis; e cinco polos no Acre nas cidades de Brasiléia, Cruzeiro do Sul, Rio Branco, Sena Madureira e Tarauacá. É importante ressaltar que nesse segundo vestibular a maioria dos polos do Acre foram contemplados com a reoferta do curso de Música. O item 2.5 do edital do vestibular prevê remanejamento de vagas.

As vagas do $1^{\circ}$ e $2^{\circ}$ vestibular foram distribuídas para demanda social e a uma cota destinada a professores da rede pública (municipal ou estadual) da sede do polo ou municípios circunvizinhos, o que deixou de acontecer a partir do $3^{\circ}$ vestibular, pois os professores da rede já haviam sido contemplados. 
De acordo com os dados do SIGRA, turma de UAB2, até o $2^{\circ}$ semestre de 2014 contava com 38 alunos formados, 22 ativos e 98 evadidos. A tabela 6 apresentará os dados do $3^{\circ}$ vestibular do curso.

Tabela 6: Oferta de Vagas do 3 ำ Vestibular do Curso de Licenciatura em Música a Distância da UnB.

\begin{tabular}{lccc}
\hline \multicolumn{1}{c}{ Polo } & $\begin{array}{c}\text { Vagas demanda } \\
\text { social }\end{array}$ & $\begin{array}{c}\text { Total de vagas } \\
\text { por polo }\end{array}$ & $\begin{array}{c}\text { Vagas } \\
\text { preenchidas }\end{array}$ \\
\hline Anápolis-GO & 25 & 25 & 25 \\
Buritis-MG & 25 & 25 & 24 \\
Ipatinga-MG & 25 & 25 & 25 \\
Primavera do Leste-MT & 25 & 25 & 25 \\
Total de vagas & 100 & 100 & \\
Total de vagas do vestibular & & 100 \\
Total de vagas do preenchidas & & 99 \\
\hline
\end{tabular}

Fonte: EDITAL № 1 - UnB/UAB, DE 29 DE SETEMBRO DE 2010 e SIGRA, Outubro/2014.

Em 2010 aconteceu o terceiro vestibular, direcionado aos três novos polos: Primavera do Leste em Mato Grosso; Buritis e Ipatinga em Minas Gerais, além de reoferta em Anápolis no Goiás. Entraram 99 alunos. Os referidos alunos ainda estão em curso com 46 alunos ativos e 53 evadidos.

O curso está em sua $4^{a}$ oferta, com vestibular realizado em 2013 e entrada de 124 novos alunos em 2014.

Tabela 7: Oferta de Vagas do 4ํㅡㄴ Vestibular do Curso de Licenciatura em Música a Distância da UnB.

\begin{tabular}{lccc}
\hline \multicolumn{1}{c}{ Polo } & $\begin{array}{c}\text { Vagas por } \\
\text { demanda social }\end{array}$ & $\begin{array}{c}\text { Vagas por } \\
\text { polo }\end{array}$ & $\begin{array}{c}\text { Vagas } \\
\text { preenchidas }\end{array}$ \\
\hline Boa Vista-RR & 25 & 25 & 25 \\
Buritis-MG & 25 & 25 & 25 \\
Cruzeiro do Sul-AC & 25 & 25 & 25 \\
Porto Nacional-TO & 25 & 25 & 25 \\
Rio Branco-AC & 25 & 25 & 25 \\
Total de vagas & 125 & 125 & 125 \\
Total de vagas do vestibular & & 125 \\
Total de vagas do preenchidas & & 125 \\
\hline
\end{tabular}

Fonte: EDITAL № 1 - UnB/UAB, DE 22 DE MAIO DE 2013 e SIGRA, Outubro/2014 
A tabela 8 apresenta os alunos ingressantes do Curso de Música a Distância da UnB separados por polo e por entrada.

Tabela 8 - Alunos ingressantes do Curso de Licenciatura em Música a Distância da UnB

\begin{tabular}{|c|c|c|c|}
\hline Polo & Turma & Ingressantes & Total \\
\hline \multirow{2}{*}{ Acrelândia } & UAB 1 & 7 & \multirow{2}{*}{14} \\
\hline & UAB 2 & 7 & \\
\hline \multirow{2}{*}{ Anápolis } & UAB 2 & 40 & \multirow{2}{*}{65} \\
\hline & UAB 3 & 25 & \\
\hline \multirow{2}{*}{ Brasiléia } & UAB 1 & 12 & \multirow{2}{*}{15} \\
\hline & UAB 2 & 3 & \\
\hline Boa Vista & UAB 4 & 25 & 25 \\
\hline \multirow{2}{*}{ Buritis } & UAB 3 & 24 & \multirow{2}{*}{48} \\
\hline & UAB 4 & 24 & \\
\hline \multirow{3}{*}{ Cruzeiro do Sul } & UAB 1 & 18 & \multirow{3}{*}{66} \\
\hline & UAB 2 & 23 & \\
\hline & UAB 4 & 25 & \\
\hline Feijó & UAB 1 & 3 & 3 \\
\hline Ipatinga & UAB 3 & 25 & 25 \\
\hline \multirow{2}{*}{ Porto Nacional } & UAB 2 & 31 & \multirow{2}{*}{56} \\
\hline & UAB 4 & 25 & \\
\hline Posse & UAB 2 & 9 & 9 \\
\hline Primavera do Leste & UAB 3 & 25 & 25 \\
\hline \multirow{3}{*}{ Rio Branco } & UAB 1 & 25 & \multirow{3}{*}{52} \\
\hline & UAB 2 & 2 & \\
\hline & UAB 4 & 25 & \\
\hline \multirow{2}{*}{ Sena Madureira } & UAB 1 & 9 & \multirow{2}{*}{29} \\
\hline & UAB 2 & 20 & \\
\hline \multirow{2}{*}{ Tarauacá } & UAB 1 & 7 & \multirow{2}{*}{30} \\
\hline & UAB 2 & 23 & \\
\hline Xapuri & UAB 1 & 11 & 11 \\
\hline Total & & 473 & 473 \\
\hline
\end{tabular}

Fonte: SIGRA, Outubro/2014

A tabela 8 apresenta 0 quantitativo de todos os alunos que foram matriculados no curso, divido pelos polos e pelas entradas de UAB1, UAB2, UAB3 e UAB4, totalizando 473 alunos matriculados em 4 ofertas do curso no decorrer de 7 anos. 


\subsubsection{Estrutura do Curso}

O Curso de Licenciatura em Música a Distância da UnB de acordo com seus componentes curriculares ${ }^{12}$ tem duração mínima de quatro anos com carga horária de 3.015 horas/aula divididas em 510 horas de atividades práticas, 480 horas de estágio, 1.815 horas de conteúdo curricular, 210 horas de outras atividades.

As horas de atividades práticas são utilizadas para colocar a prática musical em primeiro lugar, são realizadas por meio das práticas instrumentais nos polos. Os instrumentos oferecidos no curso são teclado, violão, canto popular e percussão.

O estágio está relacionado à atuação docente orientada durante o curso.

As disciplinas do conteúdo curricular são organizadas em três núcleos: Núcleo de Formação Musical; Núcleo de Formação em Educação Musical; e Núcleo de Fundamentação Pedagógica.

As outras atividades são atividades de caráter complementar como atividades artístico-culturais, produção científica e de ensino.

Conta com a estrutura e o apoio dos polos de apoio presencial, intitulados pelo curso como Polos musicais, "A ideia é que os polos de apoio presencial sejam polos musicais e culturais, disseminando as práticas musicais previstas no curso e tornando o local um ponto de encontro nos municípios." (MARINS e NARITA, 2012, p.162)

A estrutura docente é composta por professores e tutores. São necessários dois professores para estruturar uma disciplina, um é responsável pela autoria da disciplina e outro pela revisão e acompanhamento de tutores. Quando necessário, o mesmo professor executa as funções de autor e revisor da disciplina. Existem dois tipos de tutores: o presencial e o a distância. O tutor presencial fica no polo, é responsável por cada turma e cuida das interações e acompanhamento dos cursistas. O tutor a distância atua no AVA fazendo o acompanhamento do desenvolvimento da aprendizagem dos alunos por disciplina e visita periodicamente o polo.

Atualmente o curso conta com 54 alunos formados das duas primeiras ofertas, 193 alunos em curso e 226 alunos evadidos.

\footnotetext{
${ }^{12}$ As informações sobre os componentes curriculares aqui apresentadas foram retiradas do artigo Licenciatura em Música a Distância na UnB: planejamento e implementação de Marins e Narita, 2012.
} 
De acordo com Marins e Narita (2012), em 2007 o curso ainda não contava com os polos devidamente montados com instrumentos musicais, em função disso o curso de Música iniciou suas atividades com disciplinas teóricas a fim de que o polo tivesse mais tempo para se adequar, porém, esta situação causou desinteresse da parte dos alunos. Como estratégia de motivação para as próximas turmas, foram inseridas no primeiro semestre de curso as disciplinas práticas de Teclado1 e Violão 1.

O Curso de Licenciatura em Música a distância da UnB teve sua 1a turma formada em dezembro de 2011, concretizando uma experiência pioneira dentro do MUS devido a união de um recital didático e uma monografia como trabalho e recital de conclusão de curso (TRCC). Foram diplomados 16 alunos no estado do Acre, representando novos professores de música.

O Projeto político pedagógico do curso apresenta como objetivos gerais:

- Formar professores de música que possam atuar em variados espaços de educação musical de forma crítica e reflexiva;

- $\quad$ Formar professores de música que atuem em variados contextos de educação musical, seja na Educação Básica (Educação Infantil, Ensino Fundamental e Ensino Médio), seja em programas e projetos sociais, escolas de música, ONGs, entre outros espaços;

- $\quad$ promover a construção do conhecimento, formando um professorpesquisador que integre ensino e pesquisa em suas ações pedagógicas;

- formar um profissional capaz de inter-relacionar os vários conhecimentos e habilidades musicais;

- $\quad$ promover a formação de um educador que aprenda com e na prática, observando, pesquisando e atuando de forma consciente nas diversas situações de aprendizagem;

- Incentivar a reflexão sobre/com a prática, objetivando a melhoria da qualidade de ensino e aprendizagem;

- despertar o interesse pela permanente busca e pesquisa para atualização e aquisição de novos conhecimentos, incentivando a formação continuada;

- $\quad$ incentivar a aprendizagem colaborativa por meio das TIC.

(PROJETO POLÍTICO PEDAGÓGICO DO CURSO DE LICENCIATURA EM MÚSICA A DISTÂNCIA DA UNB, p. 17)

Os objetivos gerais do curso visam formar professores de música que tenham conhecimento de sua área e campo de trabalho, capacidade crítica e reflexiva de sua prática docente, que promovam o conhecimento por meio do ensino e aprendizagem colaborativa e utilizem as Tecnologias da Informação e Comunicação (TIC) em sua atuação profissional.

Em 18 de agosto de 2008 foi sancionada a Lei № 11.769, que dispõe sobre a obrigatoriedade do ensino da música na educação básica.

Art. $1^{\circ} \mathrm{O}$ art. 26 da Lei no 9.394 , de 20 de dezembro de 1996, passa a vigorar acrescido do seguinte $\S 60$ : 
"Art. 26.

§ 60 A música deverá ser conteúdo obrigatório, mas não exclusivo, do componente curricular de que trata o § 20 deste artigo." (LEI No $11.769 \mathrm{DE}$ 18 DE AGOSTO DE 2008)

Essa lei trouxe um incentivo à área de Educação Musical, pois tornar o conteúdo de música obrigatório para a educação básica no Brasil significa o reconhecimento da importância da musicalização na formação do indivíduo e o aumento da demanda de professores formados.

Este estudo sobre a educação a distancia, a UAB e o curso de Música a distância da UnB foi feito para embasar teoricamente a pesquisadora. O pré-projeto da pesquisa buscava saber os principais motivos que levaram vários alunos a desistirem do curso. Espera-se que os resultados da pesquisa proposta, sobre a evasão do curso de música a distância da UnB, identifiquem os fatores que causam evasão dos alunos, para colaborar com informações que poderão dar suporte à coordenação do curso em futuras ações de retenção de alunos. 


\section{CAPÍTULO 2 - EVASÃO}

Esse capítulo tem por objetivo fazer uma fundamentação teórica, conceitual e etimológica da palavra evasão, definir o conceito de evasão que será utilizado nessa pesquisa e apresentar dados sobre a evasão do Curso de Música a Distância da UnB.

\subsection{Conceituando Evasão}

Etimologicamente, a palavra evasão vem do latim Evasio"13 - "Acção de escapar, livramento, soltura, redempção."

Corroborando com a definição, Cunha (1999) apresenta por meio do dicionário etimológico da língua portuguesa que o significado da palavra evasão é "fuga, ato de evadir-se" e que tem correspondência com a palavra evadir que em sua definição aparece como "escapar, fugir, desaparecer".

Trazendo a evasão para o âmbito escolar, Queiroz (2002) aponta que evasão é o afastamento definitivo entre um aluno e seu curso. Que o afastamento pode acontecer em qualquer estágio, ou fase, e com qualquer aluno de ensino institucionalizado.

Segundo Queiroz:

A evasão escolar está dentre os temas que historicamente faz parte dos debates e reflexões no âmbito da educação pública brasileira e que infelizmente, ainda ocupa até os dias atuais, espaço de relevância no cenário das políticas públicas e da educação em particular. (QUEIROZ, 2002, p. 1) [sic.]

Moore (2008) trata a evasão ou índice de desistência com o olhar sobre os fatores que afetam o sucesso e o fracasso dos alunos, apontando que uma das dificuldades de identificação das causas é o fato de que geralmente a desistência ocorre por um acúmulo de fatores e não somente por um único motivo.

O Ministério da Educação - MEC define evasão como a "saída definitiva do curso de origem sem conclusão, ou a diferença entre ingressantes e concluintes, após uma geração completa" (BRASIL / MEC, 1997, p. 19).

${ }^{13}$ L. QUICHERAT por F.R. dos Santos Saraiva. Novíssimo dicionário LATINO-PORTUGUÊS Etimologico, prosódico, histórico, geográfico, mitológico, biográfico, etc. (p.439) 
Segundo Vargas apud Almeida (2008), os autores geralmente, definem evasão de forma diferenciada e de acordo com critérios de categorização. Amparada na literatura do contexto, no quadro 3 a autora sintetiza algumas definições de evasão, bem como propõe a amplitude deste conceito:

\section{QUADRO 3: Definição de evasão e amplitude do conceito}

\begin{tabular}{|l|l|l|}
\hline \multicolumn{1}{|c|}{ Autores } & \multicolumn{1}{|c|}{ Definição } & \multicolumn{1}{c|}{ Amplitude do conceito } \\
\hline $\begin{array}{l}\text { Utiyama e e } \\
\text { Borba } \\
(2003)\end{array}$ & $\begin{array}{l}\text { Evasão é entendida como a saída } \\
\text { definitiva do aluno de seu curso de } \\
\text { origem, sem concluí-lo. }\end{array}$ & $\begin{array}{l}\text { Ampla. Não foi estabelecido nenhum } \\
\text { critério de tempo no curso para a saída } \\
\text { do aluno. }\end{array}$ \\
\hline $\begin{array}{l}\text { Maia e e e } \\
\text { Meireles } \\
(2005)\end{array}$ & $\begin{array}{l}\text { Evasão consiste em alunos que não } \\
\text { completam cursos ou programas de } \\
\text { estudo, podendo ser considerada } \\
\text { como evasão aqueles alunos que se } \\
\text { matriculam e desistem antes mesmo } \\
\text { de iniciar o curso. }\end{array}$ & $\begin{array}{l}\text { Especifica que mesmo os alunos que } \\
\text { nunca começaram o curso devem ser } \\
\text { considerados no cálculo das taxas de } \\
\text { evasão. }\end{array}$ \\
\hline $\begin{array}{l}\text { Abbad, } \\
\text { Carvalho } \\
\text { e Zerbini } \\
\text { (2005) }\end{array}$ & $\begin{array}{l}\text { Evasão refere-se à desistência } \\
\text { definitiva do aluno em qualquer etapa } \\
\text { do curso. }\end{array}$ & $\begin{array}{l}\text { Não deixa claro se evasão se aplicaria } \\
\text { apenas aos alunos que chegaram a } \\
\text { iniciar o curso ou se abrangeria também } \\
\text { àqueles que apenas se matricularam e } \\
\text { nunca iniciaram o curso. }\end{array}$ \\
\hline
\end{tabular}

Fonte: Vargas apud Almeida, O.C.S. (2008, p.2)

As definições apresentadas no quadro e pelo MEC se complementam e dão norte a esta pesquisa que considera que evasão é a saída definitiva do curso de origem sem conclusão, ou a diferença entre ingressantes e concluintes.

\subsubsection{Modelo de Evasão no Ensino Superior}

Tinto (1973) é um dos autores mais citados no que diz respeito ao assunto evasão no ensino superior, segundo Walter (2006). Ele apresenta quatro motivos que geram evasão de estudantes de ensino superior:

1. O estudante que não consegue acompanhar o curso devido às dificuldades acadêmicas;

2. O fato de que o ensino superior não atendeu às necessidades, desejos ou interesses do indivíduo;

3. O estudante que se matricula, mas não inicia o curso;

4. O estudante que faz transferência de curso ou instituição.

De acordo com Amidani apud Walter-Moura (2006), o modelo de Tinto (1975, 1987, 1993) é considerado referência clássica sobre o assunto evasão. O seu modelo é um dos estudos mais citados no que se refere à evasão no ensino superior: 
O modelo analisa de que forma o compromisso do aluno com os seus objetivos de concluir o curso, o comprometimento com as suas obrigações fora do ambiente acadêmico, a sua formação escolar anterior, a integração acadêmica (intelectual) e a integração social do aluno (pessoal) se relacionam à evasão, sendo as duas últimas dimensões foco do modelo, consideradas essenciais para a persistência do estudante. Esse é um modelo teórico descritivo e explicativo para estudo do fenômeno da permanência e evasão em cursos de graduação. (WALTER, 2006, p. 51)

Tinto (1973) desenvolveu um estudo sobre evasão em cursos universitários e desenvolveu um esquema conceitual para tentar explicar esse fenômeno. Ele desenvolve um modelo em que a evasão é um processo multidimensional que acontece devido à interação entre instituição e indivíduo e que é influenciada pelas características das duas partes. A Figura 1 apresenta os elementos deste modelo. Para facilitar o entendimento da figura será feita a tradução das expressões:

> Academic System - Sistema acadêmico.

> Family background - Antecedentes familiares.

> Pre-College Schooling - Educação na Pré-escola. No Brasil seria referente à formação educacional no Ensino Fundamental e Médio.

> Individual Attributes - Atributos individuais.

> Goal Commitment-Compromisso com o objetivo.

$>$ Grade Performance-Desempenho de notas.

> Intellectual Development-Desenvolvimento Intelectual.

> Peer - Group Interactions - Iterações com os pares, grupos.

$>$ Faculty Interactions - Interações com a faculdade.

> Academic Integration - Integração Acadêmica.

$>$ Social Integration - Integração Social.

> Ins't Commitment - Compromisso com a Instituição. 
Figura 1: Um esquema conceitual para o abandono no ensino superior segundo Vicent Tinto.

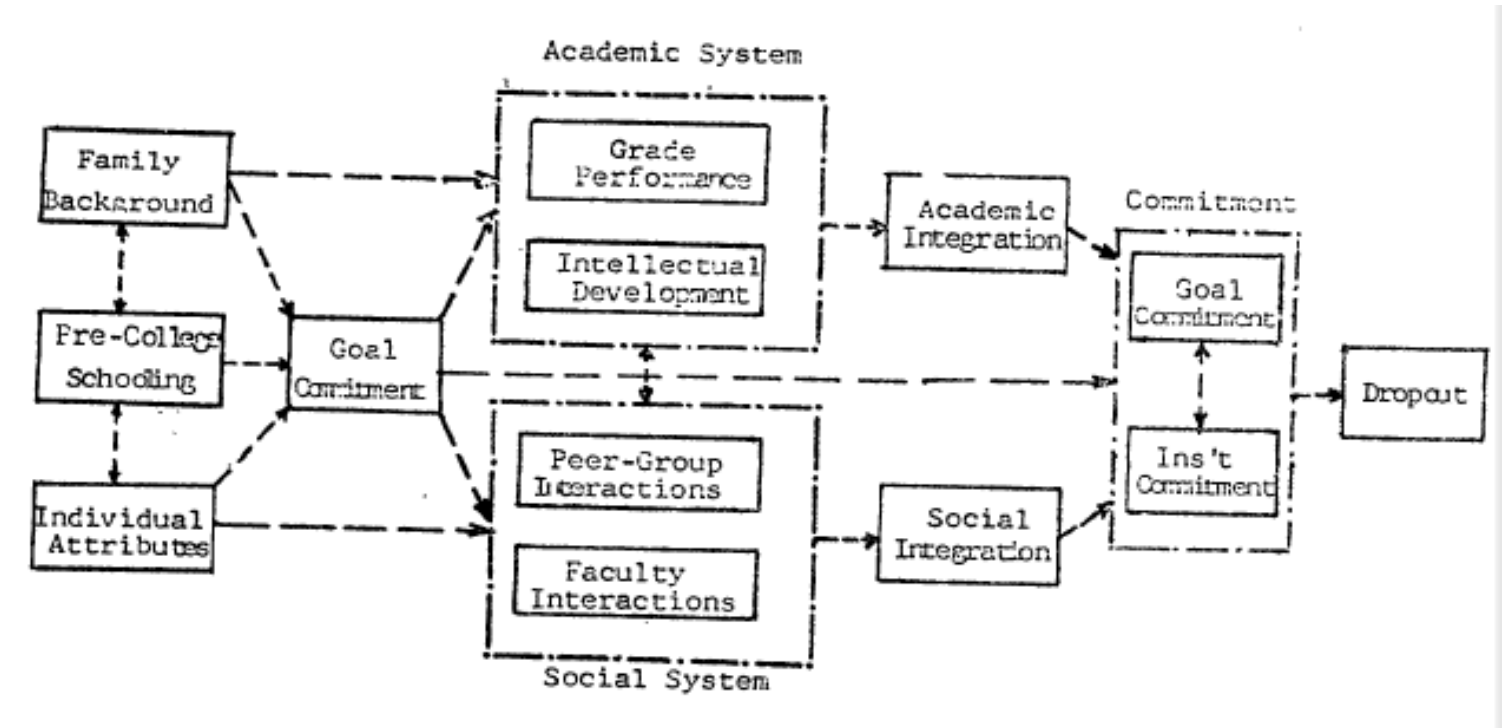

Fonte: Tinto, 1973, p.42

Tinto(1973) argumenta que os indivíduos ingressam em instituições de ensino superior com várias características individuais, familiares e educacionais que influenciam a forma de interação do estudante dentro do ambiente universitário e que essas características influenciam as expectativas e motivações para a aprendizagem dentro da universidade e que as metas pessoais assumidas são um fator central para a decisão de um estudante em continuar ou abandonar o seu curso, pois quanto maior o compromisso e a meta pessoal de terminar o curso, menores são as chances desse estudante evadir. O modelo mostra que depois de superadas as características individuais, superados o compromisso com a meta de concluir o curso e as experiências anteriores, é a integração do estudante no ambiente universitário que influenciará na continuidade do curso. Essa integração universitária é resultado da integração normativa e estrutural nos sistemas acadêmicos e sociais da faculdade.

Superada a meta inicial, é a integração do estudante nesses sistemas que leva a novas metas, novos objetivos e em diferentes graus de compromisso com a instituição, pois quanto maior a integração do estudante com as atividades universitárias, maior será seu compromisso com a instituição e com a meta de concluir o curso. Se o envolvimento com o curso e com a instituição for frágil, a probabilidade de o estudante abandonar o curso aumenta. Quando um estudante 
abandona seu curso, ele pode simplesmente abandonar o curso ou se transferir para outro curso ou instituição, ou por fim abandonar o ensino superior completo. O que pode influenciar essa decisão nessa fase é o compromisso com a instituição e o objetivo de concluir o curso mesmo com pouca experiência acadêmica e integração social.

O nível de comprometimento do estudante tem que ser compatível com as metas da instituição, caso haja desequilíbrio, aumentam as chances de o estudante evadir ou procurar uma instituição com metas mais fáceis de serem alcançadas.

De acordo com Tinto (1973), outro fator que influencia essa evasão é a mudança do mercado de trabalho, que influencia nos objetivos profissionais do estudante, que por sua vez poderá reavaliar seus objetivos de formação profissional e querer mudar as metas. Caso isto aconteça, o estudante poderá abandonar o curso mesmo que tenha se integrado na instituição, seria um abandono voluntário ao invés de demissão. Tinto (1973) ainda afirma que se o compromisso do estudante com a instituição for forte ele poderá permanecer no curso apesar de ter pouco comprometimento com a conclusão do curso e considerar os benefícios de ter experiência adquirida no ambiente acadêmico e um diploma universitário.

\subsubsection{Evasão na EAD}

Walter (2006) apresenta que a evasão em cursos a distância está sendo investigada de variadas formas, com foco na retenção dos alunos. Muito se procura suas causas, fatores que levam os alunos da educação a distância a desistirem de seus cursos e a resolução desse problema. Pesquisas procuram identificar os fatores, encontrar as motivações para que eles fiquem e avançam seus estudos buscando respostas de forma quantitativa e qualitativa para conseguir mapear 0 esvaziamento dos cursos.

Os pesquisadores Xenos, Pierrakeas e Pintelas (2002) estudam sobre as particularidades da educação ofertada por meio do uso de computadores e tecnologia em geral. Fizeram uma pesquisa sobre os fatores que levam os alunos que estudam em nível universitário por meio da educação a distância a abandonarem o seu curso. Escolheram trabalhar com uma turma do Curso de 
Informática da Faculty of Science and Technology of the Hellenic Open University ${ }^{14}$ nos dois primeiros anos letivos da Hellenic Open University. O objetivo da pesquisa foi investigar as principais causas de abandono dos alunos.

Xenos, Pierrakeas e Pintelas (2002) discutem que

Os fatores históricos que afetam as desistências no ensino à distância de
nível universitário podem ser classificados da seguinte forma: (a) fatores
internos relacionados aos estudantes, percepção e locus de controle, (b)
fatores relacionados ao curso e os tutores e (c) fatores relacionados a
certas características demográficas dos alunos. (XENOS, PIERRAKEAS E
PINTELAS, 2002, p.3)

Fatores internos podem ser usados como preditores de evasão. São interpretados como a percepção dos alunos em relação às dificuldades para realização do curso; e seus níveis de motivação e de persistência em relação ao curso; e as influências de familiares e intrapessoais. Esses fatores internos podem ser usados como preditores de desistência em cursos a distância. Apesar de ser abstrato e difícil de medir, o lócus de controle tem sido considerado um fator muito importante para a evasão.

Levenson (1973, 1974, 1981) apud Pasquali et al.(1998) postulou três dimensões no Locus de Controle, a saber:

- dimensão pessoal: a fonte de controle é o próprio indivíduo;

- dimensão social: a fonte de controle é representada pelos outros poderosos;

- dimensão impessoal: a fonte de controle é a sorte, o acaso, ou ainda o destino.

Os fatores relacionados ao curso e os tutores diz respeito à qualidade $\mathrm{e} o$ grau de apoio ao estudante, os meios de comunicação e o contato com o tutor, a carga de trabalho dos módulos e a quantidade de trabalhos escritos.

A pesquisa de Xenos, Pierrakeas e Pintelas (2002) apresenta o perfil do aluno como características demográficas e dá foco à idade e o sexo como influenciadores na evasão.

Para coleta de dados foram utilizados dados de registros do curso, questionário e entrevista por telefone. Os resultados concluíram que o equipamento básico do curso de informática, que neste caso é o computador, foi utilizado pela maioria dos alunos, que utilizaram e-mail para se comunicar com o tutor, além do

\footnotetext{
${ }^{14}$ Tradução de Faculty of Science and Technology of the Hellenic Open University - Faculdade de Ciências e Tecnologia da Universidade Aberta Helénica
} 
correio convencional; concluiu também que os alunos receberam algum tipo de ensino sobre informática antes de entrar no curso. $\mathrm{Na}$ entrevista por telefone, foram apresentadas três questões sobre os possíveis motivos de desistência, os alunos foram questionados sobre as razões para a desistência, a opinião sobre o tutor e a opinião sobre a Hellenic Open University. A análise de conteúdo apontou cinco grandes categorias de evasão: profissional; acadêmica; saúde; motivos familiares; e pessoais.

A análise sobre o perfil dos alunos verificou que a carga de trabalho influencia na evasão dos alunos concentrados entre 29-40 anos. A relação entre idade e desistência mostrou que a evasão é $24,4 \%$ para os alunos com idade abaixo de 29 anos, os alunos com idade entre $29-35$ apresentaram uma evasão de $29,5 \%$, para os de 35-39 anos a taxa foi de $31,8 \%$ e com um percentual pouco mais elevado ficaram os alunos acima de 40 anos, apresentando ter maior tendência à evasão.

Os pesquisadores fazem a relação das atividades concluídas com a evasão e verificam que os alunos que concluem as duas primeiras atividades do curso tem mais propensão a continuar.

Quanto ao gênero, verificou-se que os alunos do sexo masculino iniciam o curso em maior quantidade, mas as alunas do sexo feminino que entram têm uma maior tendência a persistir, no entanto devido ao baixo percentual estatístico que mostra a correlação entre desistência e sexo, a pesquisa apresentou que as taxas globais de abandono são semelhantes entre homens e mulheres, que eles têm semelhante tendência a evasão.

Relacionando a evasão com o estado civil, entre os alunos solteiros e os casados e com filhos, não houve nenhuma relação de evasão por esse motivo, mostrando que os alunos casados se organizam com a família para acompanhar 0 curso.

Verificou-se que $95,9 \%$ dos alunos que continuaram seus estudos possuíam ou usavam um computador em casa ou no trabalho e que $84,1 \%$ se comunicavam com o tutor e enviavam trabalhos via e-mail. Chegaram à conclusão de que a maioria dos alunos que optam por entrar no curso de Informática apresentam um conhecimento prévio em informática e que é muito difícil para um estudante terminar o primeiro ano de curso sem ter um computador e e-mail.

Parte da pesquisa aconteceu por ligação telefônica, na qual fizeram uma entrevista pedindo aos alunos que dessem seu parecer sobre três questões: "(a) as 
razões para a desistência, (b) a sua opinião sobre o seu tutor e (c) a sua opinião sobre a Hellenic Open University em geral." (Xenos, Pierrakeas e Pintelas, 2002, p.373). O percentual de respostas foi de $97 \%$ dos alunos evadidos, uma pequena parte estava com os contatos desatualizados ou não tinham sido registrados pela universidade.

Aos alunos foi pedido que dessem mais que um motivo para justificar seu abandono, porém a maioria deles ofereceu apenas uma ou duas razões ficando com 1,44 de resposta por alunos. Por meio de uma análise de conteúdo foram agrupadas cinco importantes categorias:

1. Profissional - em que $62,1 \%$ dos estudantes apontaram como sendo motivo de sua evasão os motivos profissionais,

2. Acadêmica - $46,2 \%$ desistiu por motivos acadêmicos,

3. Motivos familiares - contaram com $17,8 \%$

4. Saúde - contribuiu para $9,5 \%$ de evasão

5. Motivos pessoais - apresentou $8,9 \%$ dos fatores.

$\mathrm{Na}$ questão em que foram indagados sobre a atuação do tutor, 81,7\% dos alunos disseram que não tinham problemas com seu tutor e que se sentiram apoiados por ele enquanto estudavam, mas $18,3 \%$ dos alunos relataram que tiveram problemas com seu tutor. A maioria destes sentiu que o tutor não conseguiu ajudálos o suficiente para entender o material de estudos e completar as tarefas escritas. Outros relataram incapacidade do tutor para apoiá-los para superar as dificuldades não acadêmicas. Problemas de comunicação, lentidão nas respostas das atividades propostas e dificuldade de encontra-los por telefone foram relatados como problemas com o tutor. Alguns alunos afirmaram que o tutor não passava segurança de que sabia o conteúdo o suficiente para ensiná-los e que os encontros presenciais eram mal sucedidos.

$\mathrm{Na}$ questão em que falaram sobre a Hellenic Open University os alunos disseram que ela foi criada para cobrir uma necessidade existente da comunidade helênica e que pensavam positivamente sobre sua atuação.

Xenos, Pierrakeas e Pintelas (2002), após analises dos dados, concluíram que a maioria dos alunos que optam por continuar a cursar Informática já estão familiarizados com o campo o suficiente para utilizar um computador e um e-mail e que é muito difícil um aluno prosseguir num curso a distância, concluir seu primeiro ano de estudos sem possuir um computador e um e-mail. 
Walter (2006) desenvolveu estudos sobre a construção e validação da escala de comportamentos e atitudes do aluno em relação a cursos a distância, analisou o relacionamento entre características da clientela (idade, gênero, participação anterior em curso a distância, pagamento do curso pelo aluno e valor instrumental do treinamento), características do curso (semipresencial ou totalmente a distância) e comportamentos e atitudes do aluno em relação a cursos a distância com a variável critério evasão. Os cursos escolhidos foram Formação de Consultores; e Mediação e Arbitragem. O 1ำ oferecido totalmente a distância e $02^{\circ}$ na modalidade semipresencial, ambos oferecidos pelo Centro de Educação Tecnológica MSD Escola Aberta (MSD).

Em sua pesquisa, o critério evasão são as variáveis em um curso a distância que estavam significativamente relacionadas com evasão como tipo do curso, participação anterior em curso a distância, pagamento de curso, comportamentos e atitudes do aluno em relação a cursos a distância, denominado fatores intrínsecos e extrínsecos positivos ou negativos relacionados a cursos a distância.

A pesquisa sobre comportamentos e atitudes dos alunos em relação a cursos a distância como preditores de evasão de Walter (2006) aponta questões relacionadas a organização da agenda de forma a determinar horários específicos para realizar o curso a distância, elaboração de plano de estudos, facilidade de realizar o curso a distância, sentimento favorável ao estudo individual, leitura de materiais sobre as características do curso, conciliação do curso com atividades familiares e profissionais, informações sobre o curso antes da matrícula, sentimento de apoio pelo tutor, satisfação com as notas, incentivo da família e organização para realização do curso, estímulo a participação das atividades em grupo, falta da presença física de outros alunos, falta do contato virtual, falta de aulas presenciais, dificuldade do conteúdo do curso, dificuldade de obtenção de boas notas na avaliação, dificuldade de realizar o curso dentro do prazo e dificuldade de utilização dos recursos tecnológicos de informática.

A pesquisa de Walter (2006) se faz importante por dar subsídios a novas pesquisas na área de evasão em cursos a distância devido ao levantamento sobre os comportamentos e atitudes dos alunos em relação a cursos a distância como preditores de evasão. Nessa pesquisa, foram considerados evadidos todos os alunos que não cumpriram todas as etapas do curso, com exceção dos que apenas se matricularam, mas não tiveram nenhum contato com o conteúdo do curso. Como 
parte dos resultados verificou-se que alunos com experiência em EAD evadem menos que os alunos sem experiência. (WALTER, 2006, p.118).

\subsubsection{Evasão em cursos de Música}

A única pesquisa encontrada sobre evasão em cursos de música no Brasil foi a de Estevam (2012) que realizou uma pesquisa sobre evasão em conservatórios de Minas Gerais procurando compreender possíveis causas de evasão; realizou dois estudos de caso nos conservatórios de música de Leopoldina e Juíz de Fora. Por meio de entrevistas semiestruturadas com diretores, professores e alunos concluiu que:

Os aspectos mais importantes foram identificados como reflexos de um distanciamento generalizado sobre o fenômeno observado como: (a) distância entre as propostas políticas (do governo do estado) e suas articulações pedagógicas na prática (realidade dos conservatórios); (b) distância entre as vozes e expectativas envolvidas no âmbito dos Conservatórios (documentos institucionais, direção, professores, alunos); (c) distância entre a concepção teórico-pedagógica e a prática dos atores envolvidos. (ESTEVAM, 2012, p.664)

O modelo de Tinto (1973) e os apontamentos feitos pela sistematização da pesquisa de Xenos, Pierrakeas e Pintelas (2002), Walter (2006) e Estevam (2012) orientaram esta pesquisa quanto aos motivos que podem causar evasão em cursos universitários e a construção do instrumento de coleta de dados utilizado nesta pesquisa.

\subsection{Evasão no Curso de Licenciatura em Música a Distância da UnB}

O problema de pesquisa surgiu devido à expressiva evasão dos alunos do curso de Licenciatura em Música a distância da UnB. Antes dessa pesquisa, ainda não haviam dados concretos sobre o percentual de evasão, mas o número de formados era baixo em relação aos ingressantes da $1^{\underline{a}}$ e $2^{\underline{a}}$ turma. Havia uma preocupação por parte da gestão do curso sobre o que estaria levando os alunos a desistirem, que motivos estariam influenciando a evasão neste curso.

Por esse motivo foi proposto a presente pesquisa para tentar descobrir o que estaria ocasionando esse fenômeno. Para orientar esse percurso, foram delimitados três objetivos: 
- Identificar e analisar os fatores que causam evasão dos alunos do Curso de Licenciatura em Música a Distância da UnB;

- Conhecer o perfil do aluno que evade do curso; e

- Identificar se há relação entre a especificidade do curso de música e a evasão.

Foi feito um levantamento de bibliografias que tratavam dessa temática e percebeu-se que existem estudos sobre a evasão de cursos a distância de modo geral, mas pouco se encontrou sobre evasão de curso de música presencial, menos ainda sobre evasão de cursos de música a distância.

O Curso de Licenciatura em Música está em sua $4^{\underline{a}}$ oferta e apresenta uma média de $66 \%$ de evasão, considerada alta em relação à média nacional de evasão que de acordo com o Censo EaD.Br 2013 é de 16,94\% de evasão para cursos autorizados pelo MEC. A tabela a seguir apresenta as média de evasão identificadas pelo Censo EaD.Br de 2010, 2011, 2012 e 2013.

Tabela 9: Índices de evasão registrados no período 2010-2013 pelos Censo EAD.BR realizados pela ABED.

\begin{tabular}{|l|l|l|l|l|}
\hline Tipo de cursos & 2010 & 2011 & 2012 & 2013 \\
\hline $\begin{array}{l}\text { Autorizados pelo } \\
\text { MEC }\end{array}$ & $18,6 \%$ & $20,5 \%$ & $11,74 \%^{*}$ & $16,94 \%$ \\
\hline
\end{tabular}

FONTE: Censo EAD.BR, 2013, p.32

O Censo EAD.BR é um relatório analítico da aprendizagem a distância no Brasil, é um censo coordenado pela Associação Brasileira de Educação a Distância ABED que:

visa colocar à disposição de todos os interessados informações quantitativas e análises qualitativas sobre as atividades de EAD no Brasil, abrangendo todos os níveis educacionais do sistema formal de ensino e de iniciativas de ensino não formal. (CENSO EAD.BR, 2013, p.46)

Os cursos autorizados pelo MEC tiveram uma média percentual de evasão de $18,6 \%$ em 2010, 20,5\% em 2011, esta média de 20,5\% foi utilizada para qualificação do projeto desta pesquisa; em 2012 a média de evasão no Brasil para cursos autorizados foi de $11,76 \%$ e em 2013 de 16,94\%. Ao compararmos a média de evasão do Curso de Licenciatura em Música a distância da UnB que é $66 \%$ à média nacional para os cursos a distância autorizados pelo MEC de 16,94\%, nota-se o alto percentual de evasão do curso pesquisado. 
De acordo com Ribeiro e Araujo (2012) entre os cursos ofertados por meio do sistema UAB na UnB, o curso de Música apresenta o segundo maior percentual de evasão. O gráfico 1 apresenta dados de evasão da oferta de 2007 dos cursos a distância da UnB.

Gráfico 1 - Percentual de Evasão por curso - Oferta de 2007

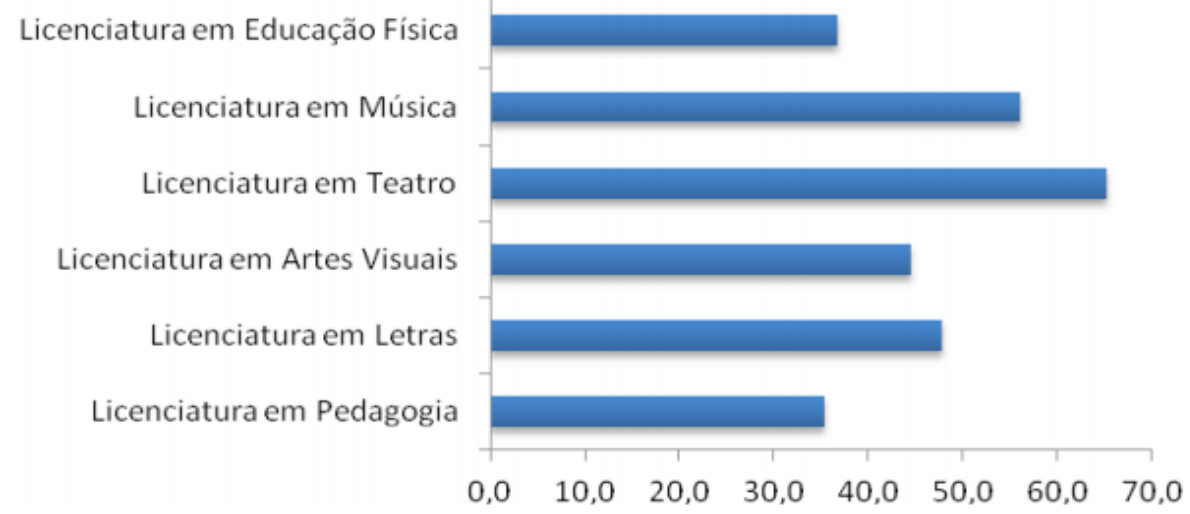

Fonte: Ribeiro e Araujo, 2012, p.132.

O gráfico mostra um cálculo feito após a formatura da $1^{\underline{a}}$ turma de todos os cursos ofertados por meio do Sistema UAB dentro da UnB. O curso de Música teve um percentual de $82 \%$ de evasão nessa turma e foi o segundo com maior evasão entre os 6 cursos ofertados de 2007 a 2010.

A tabela que segue mostra o percentual de evasão das turmas do curso pesquisado.

\section{Tabela 10 - Dados da evasão do Curso de Música a Distância da UnB.}

\begin{tabular}{|c|c|c|}
\hline & Alunos Evadidos & Percentual de Evasão \\
\hline Turma UAB1 - 2007 & 75 & $82 \%$ \\
\hline Turma UAB2 - 2009 & 98 & $62 \%$ \\
\hline Turma UAB3 - 2011 & 53 & $54 \%$ \\
\hline Total de Alunos & 193 & \\
\hline Média de Evasão & & $66 \%$ \\
\hline
\end{tabular}

Fonte: SIGRA-UnB. Outubro/2014

A primeira turma iniciada em 2007 apresentou uma evasão de 82\% dos alunos, com 75 alunos desistentes; a segunda turma iniciada em 2009 apresentou $62 \%$ de evasão, na qual 98 alunos desistiram do curso; e a terceira que iniciou suas atividades em 2011 e ainda está curso, apresenta 54\% de evasão com 53 alunos evadidos; a quarta turma iniciou suas atividades no 1\%/2014 e por ter começado suas atividades após o inicio da pesquisa, que data de outubro de 2012, a evasão desta 
turma não será estudada - os dados de evasão da UAB4 não serão tratados neste trabalho, não farão parte da pesquisa. O nome dado às turmas serve para facilitar a identificação delas. São eles: UAB1 para a primeira turma, UAB2 para a segunda, UAB3 para a terceira e UAB4 para a quarta. ${ }^{15}$

A Universidade de Brasília considera cinco formas de saída, de quebra de vínculo com os alunos. São elas:

\section{Desligamento por abandono de curso:}

Forma de exclusão do cadastro discente da UnB aplicada ao aluno que, durante um período letivo, não tenha efetivado matrícula em disciplinas, ou que, embora matriculado, tenha sido reprovado com SR em todas as disciplinas.

Aplicação:

- Aluno que não efetivar matrícula em disciplinas, sem utilizar o trancamento geral de matrícula (TGM), por dois períodos letivos consecutivos.

- Aluno que tiver mais de $25 \%$ de faltas em todas as disciplinas matriculadas, por dois períodos letivos consecutivos. ${ }^{16}$ http://www.saa.unb.br/desligamento/38-desligamento-por-abandono-decurso)

\section{Desligamento por jubilamento:}

Forma de exclusão do cadastro discente da UnB aplicada ao aluno que esgotou o tempo máximo de permanência previsto pelo Conselho Nacional de Educação - CNE para conclusão do curso.

Aplicação:

Aluno que tenha esgotado o tempo máximo de permanência estabelecido pelo CNE para a conclusão do curso. $\left({ }^{17}\right.$ http://www.saa.unb.br/desligamento/37-desligamento-por-jubilamento )

\section{Desligamento por não-cumprimento de condição}

Forma de exclusão do cadastro discente da UnB aplicada ao aluno que, tendo sido anteriormente identificado como provável desligado por rendimento acadêmico ou por tempo de permanência, não tenha cumprido, no decorrer do(s) período(s) fixado(s), a condição que the foi imposta pelos órgãos colegiados.

Aplicação: Aluno sob condição de

desligamento. $\left({ }^{18} \mathrm{http}: / /\right.$ www.saa.unb.br/desligamento/35-desligamento-pornao-cumprimento-de-condicao )

\footnotetext{
${ }^{15}$ Estes dados datam de outubro de 2014, esta data foi definida pela pesquisadora para a finalização desta pesquisa, devido à dificuldade com a coleta de dados que será apresentada no capítulo de metodologia.

16 Informações disponíveis no site: http://www.saa.unb.br/desligamento/38-desligamento-porabandono-de-curso Acessado em 25.09.2014

17 Informações disponíveis no site: http://www.saa.unb.br/desligamento/37-desligamento-porjubilamento Acessado em 25.09.2014

18 Informações disponíveis no site: http://www.saa.unb.br/desligamento/35-desligamento-por-naocumprimento-de-condicao Acessado em 25.09.2014
} 


\section{Desligamento voluntário}

Forma de exclusão do cadastro discente da UnB aplicada ao aluno que, por iniciativa própria, tenha desistido de seu vínculo com a Universidade em determinado curso.

Aplicação:

- Aluno que voluntária e definitivamente tiver desistido dos estudos.

- Aluno regular aprovado em novo concurso vestibular que, obrigatoriamente, deverá efetivar optar por uma das situações. $\left({ }^{19}\right.$ http://www.saa.unb.br/desligamento/36-desligamento-voluntario)

\section{Transferência para outras IES}

Forma de exclusão do cadastro discente da UnB aplicada ao aluno que, por iniciativa própria, mediante solicitação formal e apresentação de declaração de reserva de vaga, tenha assegurada a sua admissão por transferência facultativa ou obrigatória em outra instituição de ensino superior, nacional ou estrangeira, para continuação de estudos.

Aplicação:

Alunos regulares e prováveis desligados da UnB, com exceção dos admitidos por matrícula cortesia.( ${ }^{20} \mathrm{http}: / / \mathrm{www}$.saa.unb.br/desligamento/34transferencia-para-outras-ies)

A amostra pesquisada dos alunos evadidos apresenta neste trabalho as formas de desligamento: desligamento por não cumprir condição; e desligamento voluntário.

A amostra escolhida para ser pesquisada foi a dos alunos evadidos da $3^{\text {a }}$ turma do curso, denominada UAB3, porque os dados de e-mail e telefone destes alunos estão mais recentes e o currículo do curso já passou por algumas modificações representando o formato atual do curso, esses alunos cursaram o currículo atual. A turma de UAB 3 iniciou suas atividades com 98 alunos, destes 53 evadiram, representando $54 \%$ de evasão na turma.

\footnotetext{
19 Informações disponíveis no site: http://www.saa.unb.br/desligamento/36-desligamento-voluntario Acessado em 25.09.2014

20 Informações disponíveis no site: http://www.saa.unb.br/desligamento/34-transferencia-para-outrasies Acessado em 25.09.2014
} 


\section{CAPÍTULO 3 - METODOLOGIA}

\subsection{Definição da Amostra}

O Curso de Licenciatura em Música a Distância da UnB apresenta um percentual médio de $66 \%$ de alunos evadidos nas três ofertas do curso, conforme mostra a Tabela 10. A quarta turma iniciou suas atividades em 2014 e até a data da última coleta de dados, que aconteceu em outubro de 2014, ainda não apresentava evasão e por esse motivo não será considerada como universo desta pesquisa.

Tabela 10: Dados da evasão do Curso de Música a Distância da UnB.

\begin{tabular}{|c|c|c|}
\hline \multicolumn{2}{|c|}{ Alunos Evadidos } & \multirow{2}{*}{$\begin{array}{c}\begin{array}{c}\text { Percentual } \\
\text { de Evasão }\end{array} \\
82 \%\end{array}$} \\
\hline Turma UAB1 - 2007 & 75 & \\
\hline Turma UAB2 - 2009 & 98 & $62 \%$ \\
\hline Turma UAB3 - 2011 & 53 & $54 \%$ \\
\hline Total de Alunos & 226 & \\
\hline Médiade Evasão & & $66 \%$ \\
\hline
\end{tabular}

Fonte: SIGRA-UnB. Outubro/2014

A turma de UAB1 apresentou $82 \%$ de evasão, a UAB2 teve desistência $62 \%$ dos estudantes enquanto a UAB3 registra $54 \%$. Como o universo dos alunos evadidos era muito grande, optou-se selecionar uma amostra para a pesquisa, escolheu-se a Turma de UAB3. A tabela 11 apresenta os dados de entrada dos alunos de UAB3 por polo.

Tabela 11 - Quantitativo de alunos da Turma UAB3 por polo

\begin{tabular}{lcc}
\hline \multicolumn{1}{c}{ Polo } & $\begin{array}{c}\text { Total de vagas } \\
\text { por polo }\end{array}$ & $\begin{array}{c}\text { Vagas } \\
\text { preenchidas }\end{array}$ \\
\hline Anápolis-GO & 25 & 25 \\
Buritis-MG & 25 & 24 \\
Ipatinga-MG & 25 & 25 \\
Primavera do Leste-MT & 25 & 25 \\
Total de vagas & 100 & 99
\end{tabular}

Fonte: EDITAL № 1 - UnB/UAB, DE 29 DE SETEMBRO DE 2010 e SIGRA, Outubro/2014.

A turma UAB3 foi escolhida por ser a mais recente, porque o currículo do curso já havia passado por algumas modificações no ano de 2012 e porque esta 
turma é a que representa o curso num formato mais atual, além de os dados de email e telefone dos alunos estarem mais recentes.

Em 2010 aconteceu o terceiro vestibular, direcionado a três novos polos, Primavera do Leste em Mato Grosso, Buritis e Ipatinga em Minas Gerais e reoferta em Anápolis no estado de Goiás. A turma de UAB3 iniciou suas atividades com 99 alunos, destes 53 evadiram, representando $54 \%$ de evasão na turma. A amostra selecionada para a pesquisa foram os 53 alunos evadidos da turma UAB3. Esperase que o comportamento desta amostra possibilite uma melhor visão dos motivos que têm causado evasão no curso como um todo.

\subsection{Tipo da pesquisa}

A presente pesquisa se caracteriza como pesquisa descritiva e faz uso da metodologia survey para levantar os dados. Gil (2007) aponta que as pesquisas descritivas têm como principal objetivo a descrição das características de determinada população ou fenômeno e o uso de técnicas padronizadas de coleta de dados.

Segundo Gil (1999), as pesquisas do tipo survey caracterizam-se pela interrogação direta das pessoas que se deseja entrevistar. Dessa forma, survey é um método de pesquisa quantitativo, que pode ser descrito como a obtenção de dados ou informações de determinado grupo, representado por meio de uma população-alvo, por meio de um instrumento de pesquisa, geralmente um questionário. De acordo com o autor:

procede-se à solicitação de informações a um grupo significativo de pessoas acerca do problema estudado para em seguida, mediante análise quantitativa, obter as conclusões correspondentes dos dados coletados (GIL, 1999, p.70).

Segundo Freitas et al. (2000), o método de pesquisa survey é quantitativo, e sua escolha deve estar associada aos objetivos da pesquisa, sendo pertinente o seu uso quando o pesquisador pretende investigar o que, porque, como ou quando se dá determinada situação, a pesquisa ocorre no momento presente ou recente e trata situações reais do ambiente. Geralmente os levantamentos são feitos com uma parte da população estudada, uma amostra significativa de todo o universo, as 
conclusões apontadas são projetadas para a totalidade do universo, levando em consideração a margem de erro.

As principais vantagens de utilização dos surveys incluem o conhecimento direto da realidade, a economia e rapidez e a quantificação. Em relação ao conhecimento direto da realidade, Gil (1999) aponta que pelo fato de as próprias pessoas informarem seus comportamentos, diminui a interferência da subjetividade dos pesquisadores nas interpretações. A economia e rapidez também ganham destaque, pois é possível conseguir uma grande quantidade de dados em pouco espaço de tempo e com custo muito baixo. Além disso, os dados obtidos por meio de surveys podem ser agrupados em tabelas, o que possibilita a análise estatística.

Com o advento da tecnologia, existem hoje disponíveis softwares que proporcionam a aplicação online da pesquisa e ainda auxiliam a extração dos dados, o Formulários Google é um exemplo de ferramenta para a criação de questionários online. Geralmente, o método survey é combinado com o método estatístico para interpretação dos resultados. Destaca-se aqui, a possibilidade que o método apresenta de transformar escalas subjetivas, nominativas e ordinais em números que poderão ser tratados pelo método estatístico. Dessa forma, surveys são especialmente úteis para estudos descritivos, eficazes pesquisas de opiniões e atitudes, como é o caso da pesquisa proposta.

\subsection{Instrumento de coleta de dados}

Questionário é a "técnica de investigação composta por um número mais ou menos elevado de questões apresentadas por escrito às pessoas, tendo por objetivo o conhecimento de opiniões, crenças, sentimentos, interesses, expectativas etc." (GIL, 1999, pág. 128). Gil (1999) ainda apresenta como característica dos questionários serem propostos por escrito - questionários autoaplicados - ou formulados oralmente pelo pesquisador - questionários aplicados por entrevista.

Nesta pesquisa, o questionário foi aplicado por escrito aos participantes, enviado eletronicamente, e por telefone, visto a indisponibilidade de encontrar presencialmente com ex-alunos do curso de Música.

Para Mello (2013), o questionário deve ser administrado pelo pesquisador, que pode enviá-lo aos entrevistados, por meio impresso ou eletrônico, sendo 
possível oferecer assistência ou não para o preenchimento ou fazer a pesquisa presencialmente ou ainda via telefone.

Em relação às vantagens apresentadas pelo uso do questionário em uma pesquisa, Gil (1999) aponta cinco principais: possibilita atingir uma grande quantidade de participantes, ainda que estejam distantes geograficamente; implica menores gastos; garante o anonimato das pessoas e é provável que o participante se sinta mais confortável em responder de forma sincera as perguntas do que na conversa face a face com o pesquisador; permite que os entrevistados respondam no momento mais conveniente; e não expõe os entrevistados à influência do pesquisador.

De acordo com o autor, para se construir um questionário, é necessário traduzir os objetivos da pesquisa em questões específicas. O que irá propiciar os dados para testar as hipóteses ou esclarecer o problema da pesquisa é a resposta a essas questões, que constituem, dessa forma, parte essencial do questionário.

A formulação das perguntas deve seguir algumas normas para garantir o conteúdo das respostas, por exemplo, a formulação de perguntas de forma clara, de forma que possibilite uma única interpretação, não sugerir respostas nas perguntas e referir-se a uma única ideia por vez.

A apresentação do questionário é uma parte essencial, assim, deve-se atentar para a apresentação gráfica, para facilitar o preenchimento, e para as instruções acerca do correto preenchimento do questionário. O software utilizado para aplicação do survey nesta pesquisa foi o Formulários Google que permite construção do questionário com questões objetivas e subjetivas, dá diferentes opções para o tipo de pergunta e possibilita exportar os dados em planilhas do Software Microsoft Excel.

A pesquisa foi operacionalizada com a aplicação de um questionário semiestruturado, com 38 questões: 9 de perfil, 28 de escala Likert e 1 questão aberta, visando responder aos objetivos da pesquisa:

Objetivo Geral (G):

- Identificar e analisar os fatores que causam evasão dos alunos do Curso de Licenciatura em Música a Distância da UnB.

Objetivos Específicos:

- (E1): Conhecer o perfil do aluno que abandona o curso; 
- (E2): Identificar se há relação entre a especificidade do curso de música e a evasão.

No questionário os alunos foram indagados sobre questões relacionadas a sua escolha em cursar Música, seu conhecimento sobre o curso e as condições de oferta a distância, atuação do corpo docente e técnico-administrativo do curso, condições de acesso a plataforma e ao polo; e sobre o motivo principal que o levou a desistir do curso.

O questionário apresenta os seguintes itens para conhecer o perfil do estudante:

1. Gênero;

2. Idade;

3. Estado Civil;

4. Se tem filhos;

5. Polo;

6. Nível de formação antes de iniciar o curso de Música;

7. Se exercia alguma profissão durante o curso;

8. Qual era a profissão exercida;

9. Quantas horas por semana trabalhava durante o curso.

A escala Likert foi utilizada nesta pesquisa porque, de acordo com Pasquali (2010), ela apresenta uma maneira de criar normas de interpretação baseadas no grupo de respostas, nos quais a média de resposta do grupo será o ponto de referência.

De acordo com Pasquali (2010, p. 129) "a técnica de Rensis Likert (1932) talvez seja a mais utilizada na construção de escalas psicométricas e é conhecida como método dos pontos somados (method of summated ratings)."

As 28 questões de escala Likert desta pesquisa foram construídas com 5 opções de resposta. Essa escala pode ser construída com a quantidade de 3 a 10 opções de respostas, porém, são mais utilizadas as de 5 e de 7 opções.

$\mathrm{O}$ quadro 4 a seguir apresenta as questões do questionário e sigla indicando a qual objetivo ela pretende responder. Quanto a opção de resposta, foram escolhidas duas escalas do tipo Likert. As primeiras quatro questões apresentam como opção de resposta: 
- Discordo totalmente;

- Discordo;

- Nem concordo, nem discordo;

- Concordo;

- Concordo totalmente.

As demais questões apresentam como opção de resposta:

- Nunca;

- Quase Nunca;

- Às vezes;

- Quase sempre;

- Sempre.

O quadro a seguir apresenta as questões do questionário, indicando o objetivo com o qual ela tem relação e o que se pretende conhecer por meio dela.

\section{Quadro 4 - Questões do questionário Evasão em Música.}

\begin{tabular}{|c|c|c|c|}
\hline & \multicolumn{3}{|c|}{$\begin{array}{l}\text { A escala utilizada nas questões de } 1 \text { a } 4 \text { é constituída pelas opções: } \\
\text { Discordo totalmente, Discordo, Nem concordo, nem discordo, Concordo, Concordo totalmente. }\end{array}$} \\
\hline & Questão & $\begin{array}{l}\text { Relação } \\
\text { com o } \\
\text { objetivo }\end{array}$ & Pretensão \\
\hline Q1 & $\begin{array}{l}\text { O Curso de Licenciatura em Música foi sua } 1^{\underline{a}} \\
\text { opção de curso no vestibular? }\end{array}$ & E1 e E2 & $\begin{array}{l}\text { Saber se o aluno queria fazer outro curso, } \\
\text { mas por falta de opção se matriculou no curso } \\
\text { de Música. }\end{array}$ \\
\hline Q2 & $\begin{array}{l}\text { Você escolheu cursar Licenciatura em } \\
\text { Música por falta de outras opções de curso? }\end{array}$ & E1 e E2 & $\begin{array}{l}\text { Saber se o aluno queria fazer outro curso, } \\
\text { mas por falta de opção se matriculou no curso } \\
\text { de Música. }\end{array}$ \\
\hline Q3 & $\begin{array}{l}\text { Você procurou ler os materiais que } \\
\text { informavam sobre as características do curso } \\
\text { de Licenciatura em Música, como prazos, } \\
\text { atividades previstas e atuação profissional? }\end{array}$ & E2 & $\begin{array}{l}\text { Saber se o aluno se informou sobre as } \\
\text { especificidades do curso de Música }\end{array}$ \\
\hline \multirow[t]{2}{*}{ Q4 } & $\begin{array}{l}\text { Você tinha conhecimento de informática } \\
\text { básica antes de iniciar o curso (ligar } 0 \\
\text { computador, trabalhar com editor de textos, } \\
\text { armazenar arquivos, entre outros)? }\end{array}$ & G e E1 & $\begin{array}{l}\text { Sabe se o aluno tinha familiaridade com as } \\
\text { TIC. }\end{array}$ \\
\hline & \multicolumn{3}{|c|}{$\begin{array}{l}\text { A escala utilizada nas questões de } 5 \text { a } 29 \text { é constituída pelas opções: } \\
\text { Nunca, Quase Nunca, Às vezes, Quase sempre, Sempre. }\end{array}$} \\
\hline Q5 & Sentiu-se confortável em estudar sozinho? & G e E1 & $\begin{array}{l}\text { Saber se o aluno se sente bem, confortável ao } \\
\text { estudar sozinho, se demonstra perfil favorável } \\
\text { ao estudo a distância }\end{array}$ \\
\hline Q6 & $\begin{array}{l}\text { Você elaborou um plano de estudos com } \\
\text { reserva de horários para realizar as } \\
\text { atividades do curso? }\end{array}$ & G e E1 & $\begin{array}{l}\text { Saber se o aluno se organizou para estudar } \\
\text { ou se foi orientado a se organizar }\end{array}$ \\
\hline Q7 & $\begin{array}{l}\text { Achou fácil realizar as disciplinas, sendo elas, } \\
\text { à distância? }\end{array}$ & G e E1 & $\begin{array}{l}\text { Saber se o aluno se adaptou ao estudo a } \\
\text { distância, se teve facilidade em estudar a } \\
\text { distância. }\end{array}$ \\
\hline
\end{tabular}




\begin{tabular}{|c|c|c|c|}
\hline \multicolumn{4}{|c|}{ Continuação do Quadro 4 - Questões do questionário } \\
\hline Q8 & $\begin{array}{l}\text { Teve dificuldades de acesso à computadores } \\
\text { ou internet? }\end{array}$ & G & $\begin{array}{l}\text { Saber se o aluno iniciou o curso preparado } \\
\text { com o material básico para cursar as } \\
\text { disciplinas, considerando computador e } \\
\text { acesso à internet como itens básicos para se } \\
\text { fazer um curso a distância. }\end{array}$ \\
\hline Q9 & $\begin{array}{l}\text { Durante o curso teve dificuldades em utilizar } \\
\text { os recursos tecnológicos de informática } \\
\text { (Internet, correio eletrônico, chat, fórum, } \\
\text { recursos da plataforma moodle, entre } \\
\text { outros)? }\end{array}$ & $\mathrm{G}$ & $\begin{array}{l}\text { Saber se o aluno foi prejudicado por não } \\
\text { saber informática, por não conseguir realizar } \\
\text { as atividades devido à falta de conhecimento } \\
\text { dos recursos tecnológicos }\end{array}$ \\
\hline Q10 & entiu-se apoiado pelo tutor a distância? & G & $\begin{array}{l}\text { Saber se o aluno sentiu-se apoiado pelo tutor } \\
\text { a distância. }\end{array}$ \\
\hline Q11 & Sentiu-se apoiado pelo tutor presencial? & G & $\begin{array}{l}\text { Saber se o aluno teve problemas de } \\
\text { relacionamento com o tutor presencial }\end{array}$ \\
\hline Q12 & $\begin{array}{l}\text { Você teve problemas de relacionamento com } \\
\text { o Coordenador do Polo? }\end{array}$ & G & $\begin{array}{l}\text { Saber se o aluno teve problemas de } \\
\text { relacionamento com o coordenador do polo. }\end{array}$ \\
\hline Q13 & $\begin{array}{l}\text { Sentiu falta do contato virtual (e-mail, chat, } \\
\text { fórum, etc) com outros alunos. }\end{array}$ & G & $\begin{array}{l}\text { Saber se o aluno teve contato virtual } \\
\text { constante com os colegas }\end{array}$ \\
\hline Q14 & Achou o conteúdo das disciplinas difícil? & G & $\begin{array}{l}\text { Saber se o aluno estava apto a acompanhar } \\
\text { as disciplinas, se consegue acompanhar o } \\
\text { nível de dificuldade de um curso da UnB }\end{array}$ \\
\hline Q15 & $\begin{array}{l}\text { Você teve dificuldades de realizar as } \\
\text { atividades das disciplinas do Núcleo de } \\
\text { Formação Musical? (Ex: Percepção e } \\
\text { Estruturação Musical, Instrumento Principal e } \\
\text { optativo, etc) }\end{array}$ & E2 & $\begin{array}{l}\text { Saber se o aluno teve dificuldades de cursar } \\
\text { as disciplinas relacionadas à parte específica } \\
\text { da Música }\end{array}$ \\
\hline Q16 & $\begin{array}{l}\text { Você teve dificuldades de realizar as } \\
\text { atividades das disciplinas do Núcleo de } \\
\text { Educação Musical? (Ex: Prática de Ensino e } \\
\text { Aprendizagem Musical, Introdução a } \\
\text { Pesquisa em Música, etc) }\end{array}$ & E2 & $\begin{array}{l}\text { Saber se o aluno teve dificuldades de cursar } \\
\text { as disciplinas relacionadas ao ensino de } \\
\text { Música, a docência. }\end{array}$ \\
\hline Q17 & $\begin{array}{l}\text { Você teve dificuldades de realizar as } \\
\text { atividades das disciplinas do Núcleo de } \\
\text { Fundamentação Pedagógica? (Ex: Leitura e } \\
\text { Produção de Texto, Teoria da Arte, etc.) }\end{array}$ & $\mathrm{G}$ & $\begin{array}{l}\text { Saber se o aluno teve dificuldades de cursar } \\
\text { as disciplinas gerais do curso. }\end{array}$ \\
\hline Q18 & $\begin{array}{l}\text { Achou difícil obter boas notas nas avaliações } \\
\text { de aprendizagem? }\end{array}$ & G & $\begin{array}{l}\text { Saber se o aluno se sentiu desestimulado por } \\
\text { não obter boas notas. }\end{array}$ \\
\hline Q19 & Você sentiu falta de aulas presenciais? & $\mathrm{G}$ & $\begin{array}{l}\text { Saber se o aluno não se adaptou ao curso a } \\
\text { distância. }\end{array}$ \\
\hline Q20 & $\begin{array}{l}\text { Sentiu falta da presença física de outros } \\
\text { alunos. }\end{array}$ & G & $\begin{array}{l}\text { Saber se o aluno não se adaptou ao curso a } \\
\text { distância, saber se ele se sentiu sozinho. }\end{array}$ \\
\hline Q21 & $\begin{array}{l}\begin{array}{l}\text { Sentiu-se estimulado a participar das } \\
\text { atividades em grupo. }\end{array} \\
\end{array}$ & G & $\begin{array}{l}\text { Saber se o aluno estava motivado a participar } \\
\text { das atividades em grupo }\end{array}$ \\
\hline Q22 & $\begin{array}{l}\text { Você foi incentivado pela minha família a } \\
\text { realizar o curso. }\end{array}$ & $\mathrm{G}$ & poio familiar. \\
\hline Q23 & $\begin{array}{l}\text { Teve dificuldades em conciliar estudos e } \\
\text { trabalho durante o curso? }\end{array}$ & $G$ & $\begin{array}{l}\text { Saber se o aluno conseguiu conciliar estudo e } \\
\text { trabalho. }\end{array}$ \\
\hline Q24 & $\begin{array}{l}\text { Você se organizou financeiramente para } \\
\text { frequentar os encontros presenciais? }\end{array}$ & G & $\begin{array}{l}\text { Saber se o aluno conseguia interagir com os } \\
\text { colegas, para não se sentir sozinho. }\end{array}$ \\
\hline Q25 & $\begin{array}{l}\text { Você procurou conciliar a sua participação no } \\
\text { curso com seus compromissos familiares? }\end{array}$ & G & $\begin{array}{l}\text { Saber se o aluno se organizou em relação as } \\
\text { questões financeiras para frequentar as aulas } \\
\text { no polo. }\end{array}$ \\
\hline Q26 & $\begin{array}{l}\text { Algum problema de saúde te impediu de } \\
\text { realizar o curso? }\end{array}$ & $\mathrm{G}$ & $\begin{array}{l}\text { Saber se algum problema de saúde o impediu } \\
\text { de continuar o curso }\end{array}$ \\
\hline Q27 & $\begin{array}{l}\text { O tempo determinado para você realizar as } \\
\text { atividades das disciplinas foi suficiente? }\end{array}$ & $\mathrm{G}$ & $\begin{array}{l}\text { Saber se o tempo dado aos alunos é } \\
\text { suficiente para concluir as disciplinas, e se a } \\
\text { quantidade de disciplinas é adequada. }\end{array}$ \\
\hline
\end{tabular}




\begin{tabular}{|c|l|c|l|l|}
\hline \multicolumn{2}{|l|}{ Continuação do Quadro 4 - Questões do questionário Evasão em Música. } \\
\hline Q28 & $\begin{array}{l}\text { Sentiu-se apoiado pelo corpo técnico- } \\
\text { administrativo do curso? }\end{array}$ & G & $\begin{array}{l}\text { Saber se o atendimento do corpo técnico- } \\
\text { administrativo do polo e da secretaria do } \\
\text { curso na UnB foi satisfatório. }\end{array}$ \\
\hline Q29 & $\begin{array}{l}\text { Você teve dificuldades de acompanhar as } \\
\text { atividades de formação musical (instrumento, } \\
\text { percepção, criação musical)? }\end{array}$ & E2 & $\begin{array}{l}\text { Saber se o aluno teve dificuldades de cursar } \\
\text { as disciplinas relacionadas à parte específica } \\
\text { da Música }\end{array}$ \\
\hline Q30 & $\begin{array}{l}\text { Se você teve outros motivos que o levou a } \\
\text { desistir do curso, por gentileza, apresente-os. }\end{array}$ & G, E1, E2 & $\begin{array}{l}\text { Esta questão aberta foi elaborada com a } \\
\text { intenção de ouvir do aluno qual foi o motivo } \\
\text { mais relevante sob o seu ponto de vista para } \\
\text { que ele desistisse do curso. }\end{array}$ \\
\hline
\end{tabular}

Fonte: Elaboração da autora (2014).

As questões foram construídas com o olhar sobre os objetivos da pesquisa, as especificidades do curso de Música e o estudo de Walter (2006) sobre Comportamentos e Atitudes do Alunos em Relação a Cursos a Distância como preditores de evasão.

Foram consideradas especificidades do curso de música e a formação musical do estudante que de acordo com o EDITAL № 1 - UnB/UAB, DE 29 DE SETEMBRO DE 2010, isto é, a junção do conhecimento de um instrumento, percepção e criação musical. Capacidade de reconhecer e realizar exercícios com valores, intervalos, acorde e compassos:

ser capaz de, por meio auditivo, identificar os materiais usados na
composição das diversas músicas, bem como reconhecer estilos musicais,
eruditos e populares, distinguir tipos de instrumentos e/ou vozes e sua
utilização e organização nos diversos estilos musicais. (EDITAL № 1 -
UnB/UAB, DE 29 DE SETEMBRO DE 2010, p.8)

Marins e Narita (2012) apresentam os dois núcleos de formação musical existentes no currículo do curso de Licenciatura em Música a Distância da UnB. Os componentes curriculares que definem a formação musical dos estudantes são as disciplinas do:

1) Núcleo de Formação Musical que inclui as disciplinas de Percepção e Estruturação Musical 1 a 4, Instrumento Principal e Optativo 1 a 7 (opções violão e teclado), Práticas de Instrumento de Percussão 1 e 2, Prática de Canto 1 e 2, Práticas Musicais da Cultura 1 a 4 e Laboratório de Música e Tecnologia.

2) Núcleo de Formação em Educação Musical, que abrange as disciplinas Prática de Ensino e Aprendizagem Musical 1 a 3, Estágio Supervisionado em Música 1 a 4, Introdução a Pesquisa em Música, Projeto em Música, Teoria da Educação Musical, Elaboração de Projeto Final de Curso e Trabalho e Recital de Conclusão do Curso. (MARINS e NARITA, 2002, p. 160)

O estudo de Walter (2006) sobre Comportamentos e Atitudes do Alunos em Relação a Cursos a Distância como preditores de evasão orientou a construção do instrumento dessa pesquisa, pois o questionário desenvolvido por Walter (2006) 
avalia comportamentos e atitudes dos estudantes durante a realização de um curso a distância o que pode gerar direcionamento sobre quais desses comportamentos e atitudes causam desistência por parte dos alunos.

\subsection{Coleta de dados}

Para se coletar os dados diretamente dos alunos, primeiramente houve uma coleta dos dados em documentos da universidade.

Para se encontrar os percentuais de evasão foram utilizados relatórios de alunos e ex-alunos do curso. O SIGRA - Sistema de Informação Acadêmica de Graduação - emite relatórios de todos os alunos matriculados no curso por polo, por entrada, contendo nomes e matrícula dos alunos. Foi feita uma contagem manual, pela pesquisadora, de todos os alunos e ex-alunos para montagem das tabelas apresentadas nos capítulos 1 e 2 deste trabalho.

Para subsidiar a pesquisa a secretaria do curso exportou do SIGRA os relatórios de alunos e ex-alunos, o histórico escolar e os registros de e-mail e telefone dos alunos evadidos. Contudo junto a esses relatórios oferecidos pelo SIGRA, a secretaria disponibilizou algumas planilhas com dados de alunos e exalunos que não conferia com os dados do SIGRA e o fato de os dados de registro da secretaria do curso serem diferentes do SIGRA ocasionou problemas na coleta desses. Durante a pesquisa, foram coletados dados dos alunos evadidos por 4 vezes o que ocasionou atraso. A $1^{\text {a }}$ coleta foi feita em maio de 2012 para o préprojeto, a $2^{\mathrm{a}}$ coleta foi feita em maio de 2013 para a qualificação em agosto de 2013 , a $3^{\text {a }}$ em junho de 2014 e mesmo assim continuava havendo divergência entre os dados. Outro problema aconteceu porque a cada semestre encerrado, o número de alunos evadidos aumentava.

Para resolver a situação optou-se por trabalhar somente com os dados do SIGRA que é o sistema oficial da UnB e a última coleta que embasou os dados apresentados nesta pesquisa foi feita em outubro de 2014.

Foi disponibilizado para a pesquisa os dados de e-mail e telefone de 10 alunos evadidos da turma de UAB2 e todos os 53 alunos evadidos da turma de UAB3.

Foi enviado um questionário por e-mail por ser essa forma de envio a mais utilizada em pesquisas anteriores, porém os resultados obtidos foram insuficientes. 
No teste foi enviado um questionário via e-mail para 10 alunos do referido curso da turma de UAB2. De 9 e-mails enviados, 5 estavam desativados e voltaram, e 4 não responderam. O teste ficou ativo por 15 dias, entre os dias 12 e 26 de agosto de 2014. Foram enviadas 2 mensagens por e-mail pedindo que eles respondessem, mas sem sucesso. Da lista de 10 alunos, foi separado 01 aluno, o teste aconteceu via ligação telefônica e foi um sucesso. $O$ aluno participou prontamente. Respondeu todas as questões e apoiou a pesquisa.

A estratégia inicial consistia no envio dos questionários por e-mail, porém, na fase de aplicação do piloto, realizada entre os dias 12 e 26 de agosto de 2014, com a turma de UAB2, identificou-se duas dificuldades, quais sejam: a desatualização dos e-mails e a baixa taxa de resposta. A partir de então, houve uma alteração na estratégia de coleta de dados: numa tentativa de obter maior número de respostas, optou-se por entrar em contato via telefone primeiramente e em seguida por e-mail.

A coleta de dados por telefone aconteceu entre os dias 15/09 e 07/10/2014. Foram feitas em média 3 ligações para cada telefone disponível nos dados de matricula do aluno, sendo que para alguns alunos constava um telefone fixo e um celular, para outros, nenhum telefone. Dos 53 alunos evadidos, 4 não tinham dados telefônicos e de e-mail em seus registros na universidade. Dos 49 contatados 25 alunos responderam. A maioria dos alunos tinham telefones desatualizados, ou as ligações acusavam telefone inexistente. Somente 37 alunos tinham telefones em seus registros. Dos 49 alunos, 21 responderam a pesquisa via ligação telefônica e 4 por e-mail. Os e-mails foram enviados aos alunos que não foram encontrados por telefone, mas houve pouco sucesso.

Tabela 12: Quantitativo e percentual de resposta do questionário.

\begin{tabular}{|c|c|c|c|}
\hline \multicolumn{4}{|c|}{ Quantitativos de respostas dos evadidos } \\
\hline Total & $\begin{array}{l}\text { Respostas } \\
\text { por E-mail }\end{array}$ & $\begin{array}{c}\text { Respostas } \\
\text { por Telefone }\end{array}$ & $\begin{array}{c}\text { Sem } \\
\text { resposta }\end{array}$ \\
\hline 53 & 4 & 21 & 28 \\
\hline & \multicolumn{2}{|c|}{25 respondidos } & 28 \\
\hline Percentual & \multicolumn{2}{|c|}{$47 \%$} & $53 \%$ \\
\hline
\end{tabular}

Fonte: SIGRA-UnB e Resultados da pesquisa. Outubro/2014

Os 25 alunos que responderam o questionário equivalem a $47 \%$ dos alunos evadidos e será com base nessas respostas que será feita a análise dos dados e considerações da pesquisa. 


\section{CAPÍTULO 4 - ANÁLISE DOS DADOS}

Neste capítulo serão apresentados os dados coletados na pesquisa, bem como as considerações referentes aos resultados.

\subsection{Análise dos dados do questionário}

\subsubsection{Perfil dos alunos}

$\mathrm{Na}$ busca de identificar e analisar os fatores que causam evasão dos alunos do Curso de Licenciatura em Música a Distância da UnB, conhecer o perfil do aluno que abandona o curso e identificar se há relação entre a especificidade do curso de música e a evasão, foi feita uma análise estatística dos dados. Para o tratamento de dados e a realização das análises estatísticas (análise de frequência e descritiva) foram utilizados os Softwares Microsoft Excel e Statusticak Package for the Social Sciences-SPSS. Os dados quantitativos do questionário serão apresentados e discutidos questão por questão.

As tabelas a seguir são referentes às informações sobre o perfil dos alunos que evadiram. Apresentarão frequência (Freq.) e percentual (Perc.) como parte dos dados. O questionário coletou dados sobre gênero, estado civil, se tem filhos, polo, escolaridade, profissão e horas trabalhadas.

Tabela 13: Perfil dos alunos - gênero, estado civil, filhos.

\begin{tabular}{ccc|ccc|ccc}
\hline \multicolumn{3}{c|}{ Gênero } & \multicolumn{3}{c|}{$\begin{array}{c}\text { Estado } \\
\text { Civil }\end{array}$} & \multicolumn{3}{c}{$\begin{array}{c}\text { Tem } \\
\text { filhos }\end{array}$} \\
\hline & Freq. & Perc. & \multicolumn{3}{c}{ Freq. } & Perc. & Freq. & Perc. \\
Feminino & 6 & $24 \%$ & Casado & 15 & $60 \%$ & Não & 11 & $44 \%$ \\
Masculino & 19 & $76 \%$ & Solteiro & 10 & $40 \%$ & Sim & 14 & $56 \%$ \\
\hline Fonte: Elaboração da autora (2015). & \multicolumn{1}{c}{} & & & &
\end{tabular}

A tabela 13 apresenta dados nos quais se verificou que a maior parte dos alunos, $76 \%$, era do sexo masculino e $24 \%$ eram do sexo feminino, que $60 \%$ eram casados e que $56 \%$ tinham filhos. 
Tabela 14: Perfil dos alunos - idade por média

Fonte: Elaboração da autora (2015).

\begin{tabular}{r|r|r|r}
\hline \multicolumn{4}{|c}{ Idade } \\
\hline $\begin{array}{r}\text { Idade } \\
\text { Mínima }\end{array}$ & $\begin{array}{c}\text { Idade } \\
\text { Máxima }\end{array}$ & $\begin{array}{c}\text { Média } \\
\text { de Idade }\end{array}$ & $\begin{array}{c}\text { Desvio- } \\
\text { padrão }\end{array}$ \\
\hline 20 & 47 & 30,84 & 7,110 \\
\hline
\end{tabular}

As respostas mostraram que o curso trabalhava com alunos entre 20 e 47 anos de idade, apresentando uma média de idade dos alunos de 30 anos.

Tabela 15: Perfil dos alunos - idade por categoria

Fonte: Elaboração da autora (2015).

\begin{tabular}{c|c|c|c}
\hline Idade & $20-29$ & $30-39$ & $40-49$ \\
\hline Quantidade & 11 & 11 & 3 \\
\hline Homens & 8 & 9 & 2 \\
\hline Mulheres & 3 & 2 & 1 \\
\hline
\end{tabular}

Ao categorizar as idades das pessoas de 20 a 29 anos, 30 a 39 anos e acima de 40 anos, percebeu-se que a quantidade de alunos da faixa etária de 20-29 anos se equipara a quantidade de alunos de 30-39 anos.

Tabela 16: Perfil dos alunos - escolaridade e profissão.

\begin{tabular}{|c|c|c|c|c|c|}
\hline \multicolumn{3}{|c|}{ Escolaridade } & \multirow{2}{*}{\multicolumn{3}{|c|}{$\begin{array}{l}\text { Você exercia alguma } \\
\text { profissão enquanto cursava } \\
\text { a graduação em Música? }\end{array}$}} \\
\hline & Freq & Perc & & & \\
\hline Ensino Médio & 16 & $64 \%$ & & Freq & Perc \\
\hline Graduação & 8 & $32 \%$ & Não & 2 & $8 \%$ \\
\hline Pós-graduação & 1 & $4 \%$ & Sim & 23 & $92 \%$ \\
\hline
\end{tabular}

Fonte: Elaboração da autora (2015).

Verificou-se que $64 \%$ dos alunos respondentes não tinham graduação, que $32 \%$ tinham uma graduação e que $4 \%$ tinha pós-graduação. Mostrou que $92 \%$ destes alunos trabalhavam durante o curso, sendo que 10 alunos, equivalentes a 40\%, trabalhavam na área de música, conforme apêndice B.

\section{Tabela 17: Perfil dos alunos - horas trabalhadas}

\begin{tabular}{l|c|c|c}
\hline $\begin{array}{l}\text { Horas } \\
\text { trabalhadas }\end{array}$ & $\begin{array}{c}30 \\
\text { horas }\end{array}$ & $\begin{array}{c}40 \\
\text { horas }\end{array}$ & $\begin{array}{c}\text { Mais de } \\
40 \mathrm{~h}\end{array}$ \\
\hline Quantidade & 4 & 10 & 11 \\
\hline Homens & 2 & 8 & 9 \\
\hline Mulheres & 2 & 2 & 2 \\
\hline
\end{tabular}

Fonte: Elaboração da autora (2015).

Identificou-se que 4 alunos trabalhavam 30 horas semanais, 10 alunos trabalhavam 40 horas semanais e que 11 alunos trabalhavam mais de 40 horas 
semanais. Esses dados indicam a dificuldade que os alunos evadidos tinham em conciliar o horário de estudo com o de trabalho. Esse dado corrobora com a pesquisa de Xenos, Pierrakeas e Pintelas (2002) que mostrou que o principal motivo de evasão de seus alunos estava relacionado a atuação profissional, na qual $62,1 \%$ dos estudantes apontaram como sendo motivo de sua evasão os motivos profissionais.

A tabela 18 apresenta a frequência ou quantidade de alunos que responderam o questionário e o percentual que esses alunos representam na pesquisa.

Tabela 18: Perfil dos alunos - polo.

Fonte: Elaboração da autora (2015).

\begin{tabular}{|c|c|c|}
\hline \multicolumn{3}{|c|}{ Polo } \\
\hline & Frequência & Percentual \\
\hline Anápolis & 4 & $16 \%$ \\
\hline Buritis & 4 & $16 \%$ \\
\hline Ipatinga & 7 & $28 \%$ \\
\hline $\begin{array}{c}\text { Primavera do } \\
\text { Leste }\end{array}$ & 10 & $40 \%$ \\
\hline Total & 25 & 100 \\
\hline
\end{tabular}

Houve uma participação maior dos alunos evadidos de Primavera do Leste responsáveis por $40 \%$ das respostas, os alunos de Ipatinga participaram com $28 \%$ das respostas e em seguida vieram os de Buritis e Anápolis com 16\% de resposta cada.

Um dos objetivos específicos da pesquisa se propôs a conhecer o perfil do aluno que abandona o curso. Os dados aqui relatados mostraram que o aluno que evade do curso de Licenciatura em Música da UnB é em sua maioria homens. A idade dos alunos foi classificada entre 20 e 40 anos, trabalham 40h semanais ou mais, a quantidade de solteiros e casados é equilibrada. Os dados mostraram também que a maioria dos estudantes entrou no curso tendo somente o ensino médio. 


\subsubsection{Questões objetivas}

Os dados quantitativos do questionário serão discutidos questão por questão e em seguida organizados em fatores relacionados aos objetivos. Serão apresentadas 29 tabelas que apresentarão os resultados das 29 questões objetivas do questionário. A estrutura das tabelas será:

- Questão - Número referente à questão do questionário.

- Pergunta - Será exposta a pergunta feita no questionário.

- Q.R. - Quantidade de respondente.

- Resposta Mínima - refere-se à posição de resposta mínima dentro da escala utilizada.

- Resposta Máxima - refere-se à posição de resposta máxima dentro da escala utilizada.

- Média - Média das respostas.

- Desvio Padrão - média dos valores absolutos dos desvios que pode ser usados para interpretar a média diminuída ou aumentada pelo desvio-padrão.

Nas questões de 1 a 4 foram utilizadas as seguintes opções de resposta de acordo com a escala Likert:

1. Discordo totalmente,

2. Discordo;

3. Nem concordo, nem discordo;

4. Concordo,

5. Concordo totalmente;

As demais questões apresentam como opção de resposta:

1. Nunca,

2. Quase Nunca,

3. Às vezes,

4. Quase sempre,

5. Sempre.

Será apresentada a média de resposta de cada item e o desvio-padrão. No apêndice $C$ se encontra a frequência das respostas dos alunos de acordo com a escala, portanto, na análise das tabelas será apresentada a frequência negativa dos 
itens que se refere à quantos alunos apontaram a questão como influenciadora de sua evasão. Por exemplo:

\begin{tabular}{lc}
\hline \multicolumn{2}{c}{$\begin{array}{c}\text { 5. Sentiu-se } \\
\text { confortável em } \\
\text { estudar sozinho? }\end{array}$} \\
\hline Sempre & 7 \\
\hline Quase sempre & 7 \\
\hline As vezes & 5 \\
\hline Nunca & 5 \\
\hline Quase nunca & 1 \\
\hline Total & 25 \\
\hline
\end{tabular}

$\mathrm{Na}$ questão acima 7 alunos (28\%) sempre se sentiram confortáveis em estudar sozinhos, 7 alunos (28\%) responderam quase sempre, 5 alunos $(20 \%)$ às vezes, 5 alunos (20\%) nunca e 1 aluno (4\%) quase nunca. Para se calcular a frequência negativa será somado os 2 itens que tendem à resposta negativa da questão, que no caso acima seria somar o nunca ao quase nunca, no qual 6 alunos (24\%) não se sentiram confortável ao estudar sozinho.

Nos casos em que a frequência da resposta às vezes estiver alta, ela será apresentada na análise. E quando houver relação com a questão 30 , as falas dos alunos serão citadas. Como 25 alunos responderam, essa citação será apresentada como aluno 1 - A1, aluno 2 - A2 e assim sucessivamente.

A seguir será apresentada a análise das respostas das questões do questionário.

Tabela 19 - Questão 1 do questionário

\begin{tabular}{|c|c|c|c|c|c|c|}
\hline Questão & Pergunta & Q.R & $\begin{array}{c}\text { Resp. } \\
\text { Mínima }\end{array}$ & $\begin{array}{c}\text { Resp. } \\
\text { Máxima }\end{array}$ & Média & $\begin{array}{c}\text { Desvio } \\
\text { Padrão }\end{array}$ \\
\hline 1 & $\begin{array}{c}\text { O Curso de Licenciatura em } \\
\text { Música foi sua 1ª opção de } \\
\text { curso no vestibular? }\end{array}$ & 25 & 1 & 5 & 3,68 & 1,406 \\
\hline
\end{tabular}

Fonte: Elaboração da autora (2015).

A questão 1 teve uma média de resposta de 3,68 com desvio padrão de 1,4. Essa questão que pretendia saber se o aluno queria fazer outro curso de graduação, mas por falta de outra opção de curso se matriculou no curso de Licenciatura em Música mostrou com uma média de resposta de 3,68 que a maioria dos alunos tinha o interesse em cursar Licenciatura em Música como sua 1aㅡ opção de curso.

A frequência nessa questão variou de 1 a 5 , isto é, de discordo totalmente a concordo totalmente. Ao se analisar a frequência dos alunos que discordam dessa 
questão, tem-se 7 alunos que corresponde a $28 \%$ dos respondentes, que não tinham o curso de Licenciatura em Música como sua 1a opção de curso.

Tabela 20 - Questão 2 do questionário

\begin{tabular}{|c|c|c|c|c|c|c|}
\hline Questão & Pergunta & Q.R & $\begin{array}{c}\text { Resp. } \\
\text { Mínima }\end{array}$ & $\begin{array}{c}\text { Resp. } \\
\text { Máxima }\end{array}$ & Média & $\begin{array}{c}\text { Desvio } \\
\text { Padrão }\end{array}$ \\
\hline 2 & $\begin{array}{c}\text { Você escolheu cursar } \\
\text { Licenciatura em Música por } \\
\text { falta de outras opções de } \\
\text { curso?" }\end{array}$ & 25 & 2 & 5 & 4,44 &, 870 \\
\hline
\end{tabular}

Fonte: Elaboração da autora (2015).

A questão 2 teve uma média de resposta de 4,44 sendo que as questões negativas foram transformadas em positivas, com desvio padrão de 1,4. Essa questão que pretendia saber se o aluno queria fazer outro curso, mas por falta de opção se matriculou no curso de Música mostrou com uma média positiva que a maioria dos alunos escolheu cursar Licenciatura em Música como sua 1ª opção de curso. De acordo com a frequência, entre os respondentes, 2 alunos escolheram cursar música por falta de outras opções de curso. Essa questão é muito importante para esta pesquisa porque aponta que a maioria dos alunos entraram no curso de Música realmente intencionados a cursar Licenciatura em Música e não porque não tinham outras opções de curso para se graduarem. A teoria de Tinto (1973) aponta que alunos que não têm uma meta pessoal de terminar o curso apresenta uma tendência a evasão e neste caso um baixo percentual (8\%) da amostra iniciou o curso sem predileção em cursar Música.

\section{Tabela 21 - Questão 3 do questionário}

\begin{tabular}{|c|c|c|c|c|c|c|}
\hline Questão & Pergunta & Q.R & $\begin{array}{c}\text { Resp. } \\
\text { Mínima }\end{array}$ & $\begin{array}{c}\text { Resp. } \\
\text { Máxima }\end{array}$ & Média & $\begin{array}{c}\text { Desvio } \\
\text { Padrão }\end{array}$ \\
\hline 3 & $\begin{array}{c}\text { Você procurou ler os materiais } \\
\text { que informavam sobre as } \\
\text { características do curso de } \\
\text { Licenciatura em Música, como } \\
\text { prazos, atividades previstas e } \\
\text { atuação profissional?" }\end{array}$ & 25 & 1 & 5 & 4,16 & 1,02794 \\
\hline
\end{tabular}

Fonte: Elaboração da autora (2015).

A questão 3 teve uma média de resposta de 4,16 com desvio padrão de 1,02.

Essa questão que pretendia saber se o aluno se informou sobre as características do curso de Licenciatura em Música, se iniciou o curso consciente de suas demandas confirmou a questão anterior que a maioria dos alunos estava consciente de sua escolha pelo curso. Essa questão mostrou que a maioria dos alunos tinham 
informações sobre os prazos, atividades previstas para o curso e atuação profissional. A frequência negativa dessa questão informou que 2 alunos não estavam conscientes dessas informações.

A10 - "Acreditei que o tempo necessário para fazer as disciplinas fosse menor do que realmente era. Queria fazer um curso somente para fazer um serviço social, pensei que estudando só aos fins de semana fosse suficiente. Quando vi que era necessário no mínimo 4 h de estudos por dia desisti."

\section{Tabela 22 - Questão 4 do questionário}

\begin{tabular}{|c|c|c|c|c|c|c|}
\hline Questão & Pergunta & Q.R & $\begin{array}{c}\text { Resp. } \\
\text { Mínima }\end{array}$ & $\begin{array}{c}\text { Resp. } \\
\text { Máxima }\end{array}$ & Média & $\begin{array}{c}\text { Desvio } \\
\text { Padrão }\end{array}$ \\
\hline 4 & $\begin{array}{c}\text { Você tinha conhecimento de } \\
\text { informática básica antes de } \\
\text { iniciar o curso (ligar o } \\
\text { computador, trabalhar com } \\
\text { editor de textos, armazenar } \\
\text { arquivos, entre outros)? }\end{array}$ & 25 & 4 & 5 & 4,64 & 0,4899 \\
\hline
\end{tabular}

Fonte: Elaboração da autora (2015).

A questão 4, a qual obteve resposta de 4 a 5, esclareceu que todos os alunos tinham conhecimento de informática básica, não sendo esse um fator que influenciou na evasão. Demostraram ter facilidade com as TIC.

Xenos, Pierrakeas e Pintelas (2002) afirmam que a maioria dos alunos que optam por continuar a cursar um curso a distância já estão familiarizados com a informática o suficiente para utilizar um computador e um e-mail. Neste caso a facilidade no uso das TIC não foi suficiente para manter os alunos no curso.

\section{Tabela 23 - Questão 5 do questionário}

\begin{tabular}{|c|c|c|c|c|c|c|}
\hline Questão & Pergunta & Q.R & $\begin{array}{c}\text { Resp. } \\
\text { Mínima }\end{array}$ & $\begin{array}{c}\text { Resp. } \\
\text { Máxima }\end{array}$ & Médlia & $\begin{array}{c}\text { Desvio } \\
\text { Padrão }\end{array}$ \\
\hline 5 & $\begin{array}{c}\text { Sentiu-se confortável } \\
\text { em estudar sozinho? }\end{array}$ & 25 & 1 & 5 & 3,4 & 1,47196 \\
\hline
\end{tabular}

Fonte: Elaboração da autora (2015).

A questão 5 apresentou uma média de resposta de 3,4 com desvio padrão de 1,47. Esse desvio-padrão é relevante. A frequência negativa mostra que 6 alunos, ou seja $24 \%$ dos alunos respondentes não se sentiam confortáveis em estudar só, e que 5 alunos (20\%) às vezes se sentiam confortáveis, sendo que essa é uma característica importante para um estudante de curso a distância. Os estudos de Walter (2006) verificaram que alunos com experiência em EAD evadem menos que os alunos inexperientes na modalidade. 
A4 - "Me senti sozinha para fazer as atividades de grupo, as gravações musicais, a solidão, o fato de ser a única aluna de Campo Verde me atrapalhou, acho que se tivesse outros colegas na cidade teria mais facilidade."

\section{Tabela 24 - Questão 6 do questionário}

\begin{tabular}{|c|c|c|c|c|c|c|}
\hline Questão & Pergunta & Q.R & $\begin{array}{c}\text { Resp. } \\
\text { Mínima }\end{array}$ & $\begin{array}{c}\text { Resp. } \\
\text { Máxima }\end{array}$ & Média & $\begin{array}{c}\text { Desvio } \\
\text { Padrão }\end{array}$ \\
\hline 6 & $\begin{array}{c}\text { Você elaborou um plano de } \\
\text { estudos com reserva de } \\
\text { horários para realizar as } \\
\text { atividades do curso? }\end{array}$ & 25 & 1 & 5 & 3,88 & 1,23558 \\
\hline
\end{tabular}

Fonte: Elaboração da autora (2015).

A média dessa questão mostrou que a maioria dos alunos se organizou para cursar as disciplinas, porém o fator problemas com as disciplinas foi uma categoria bastante citada pelos alunos na questão 30 quando foram questionados sobre os motivos que mais influenciaram na evasão, isto é, por mais que tenham se organizado para cursar as disciplinas não conseguiram acompanhá-las. De acordo com a frequência negativa, 3 alunos (12\%) não elaboraram nenhum tipo de plano de estudos e 5 alunos (20\%) elaboraram às vezes. Moore (2010, pg.187) afirma que "os hábitos e as aptidões de estudo dos alunos determinam, em grande parte, o sucesso nas aulas on-line". Neste caso, mesmo tendo se organizado, os alunos não conseguiram continuar.

Tabela 25 - Questão 7 do questionário

\begin{tabular}{|c|c|c|c|c|c|c|}
\hline Questão & Pergunta & Q.R & $\begin{array}{c}\text { Resp. } \\
\text { Mínima }\end{array}$ & $\begin{array}{c}\text { Resp. } \\
\text { Máxima }\end{array}$ & Média & $\begin{array}{c}\text { Desvio } \\
\text { Padrão }\end{array}$ \\
\hline 7 & $\begin{array}{c}\text { Achou fácil realizar as } \\
\text { disciplinas, sendo elas, à } \\
\text { distância? }\end{array}$ & 25 & 1 & 5 & 2,84 & 1,57268 \\
\hline
\end{tabular}

Fonte: Elaboração da autora (2015).

Essa questão indica que a maioria dos alunos achou difícil realizar as disciplinas a distância. Demonstraram que mesmo se organizando com plano de estudos e tendo facilidade com as TIC, acharam difícil realizar as disciplinas a distância. Essa foi a questão que teve a segunda maior frequência negativa, na qual 10 alunos (40\%) apontaram que acharam difícil realizar as disciplinas e 7 alunos (28\%) acharam difícil às vezes. Moore (2010) aponta que a probabilidade dos alunos desistirem de um curso é maior se o curso for muito difícil e exigir muito tempo de dedicação. 
A3 - "Tive dificuldades de aprender através da modalidade a distância. Percebia que não conseguia absorver nem $70 \%$ do curso, por isso desisti."

A22 - "A quantidade de vídeos exigidos no encontro presencial era grande, a estrutura pedagógica e metodológica do curso a distância era desmotivadora, não conseguia absorver os conteúdos através da metodologia a distância. Não conseguia ter o rendimento almejado a nível de conhecimento. Continuo cursando música num curso presencial da UEG."

\section{Tabela 26 - Questão 8 do questionário}

\begin{tabular}{|c|c|c|c|c|c|c|}
\hline Questão & Pergunta & Q.R & $\begin{array}{c}\text { Resp. } \\
\text { Mínima }\end{array}$ & $\begin{array}{c}\text { Resp. } \\
\text { Máxima }\end{array}$ & Média & $\begin{array}{c}\text { Desvio } \\
\text { Padrão }\end{array}$ \\
\hline 8 & $\begin{array}{c}\text { Teve dificuldades de } \\
\text { acesso à computadores } \\
\text { ou internet? }\end{array}$ & 25 & 1 & 5 & 4,04 & 1,24097 \\
\hline
\end{tabular}

Fonte: Elaboração da autora (2015).

Com média de resposta 4,04 a maioria os alunos demostraram ter facilidade de acesso a computadores e internet. A frequência negativa mostra que 3 alunos (12\%) tiveram dificuldades de acesso e 6 alunos (24\%) tiveram às vezes.

A25 - "Nos 2 semestres que cursei eu não tinha internet instalada em casa, por isso, precisava ir ao polo para realizar minhas tarefas diárias. A dificuldade estava nos horários de funcionamento do polo que não se encaixavam com meus horários de disponibilidade para realizar as tarefas. Sendo assim, fui desligado do curso por ter reprovado em muitas matérias."

\section{Tabela 27 - Questão 9 do questionário}

\begin{tabular}{|c|c|c|c|c|c|c|}
\hline Questão & Pergunta & $\begin{array}{l}Q \\
R \\
R\end{array}$ & $\begin{array}{l}\text { Resp. } \\
\text { Mínima }\end{array}$ & $\begin{array}{l}\text { Resp. } \\
\text { Máxima }\end{array}$ & Média & $\begin{array}{l}\text { Desvio } \\
\text { Padrão }\end{array}$ \\
\hline 9 & $\begin{array}{c}\text { Durante o curso teve dificuldades } \\
\text { em utilizar os recursos } \\
\text { tecnológicos de informática } \\
\text { (Internet, correio eletrônico, chat, } \\
\text { fórum, recursos da plataforma } \\
\text { moodle, entre outros)? }\end{array}$ & $\begin{array}{l}2 \\
5\end{array}$ & 1 & 5 & 4 & 1,47196 \\
\hline
\end{tabular}

Fonte: Elaboração da autora (2015).

Essa questão apresentou que em média os alunos tiveram facilidades em utilizar os recursos tecnológicos de informática, mas o desvio-padrão é relevante. A frequência negativa aponta que $20 \%$ dos respondentes, quais sejam, 5 alunos, tiveram dificuldades em utilizar os recursos tecnológicos de informática. Essa questão contradiz a questão 4 , em que todos os alunos disseram ter facilidade com o uso das TIC. 
Tabela 28 - Questão 10 do questionário

\begin{tabular}{|c|c|c|c|c|c|c|}
\hline Questão & Pergunta & Q.R & $\begin{array}{c}\text { Resp. } \\
\text { Mínima }\end{array}$ & $\begin{array}{c}\text { Resp. } \\
\text { Máxima }\end{array}$ & Média & $\begin{array}{c}\text { Desvio } \\
\text { Padrão }\end{array}$ \\
\hline 10 & $\begin{array}{c}\text { Sentiu-se apoiado pelo } \\
\text { tutor/professor a } \\
\text { distância? }\end{array}$ & 25 & 1 & 5 & 3,56 & 1,32539 \\
\hline
\end{tabular}

Fonte: Elaboração da autora (2015).

Esta questão é muito importante na pesquisa, pois o tutor a distância é o profissional docente que acompanha de perto os alunos por meio da plataforma de aprendizagem. Com uma média de 3,56 de resposta, a maioria dos alunos apontou que se sentiram apoiados pelo tutor/professor a distância enquanto que 3 alunos $(12 \%)$, por meio da frequência negativa, disseram que não se sentiram apoiados por este profissional e 11 alunos (44\%) disseram se sentir apoiados as vezes. Moore (2010, p.185) afirma que uma característica que pode afetar o sucesso dos alunos é "o grau de apoio ao aluno e a quantidade e a natureza do feedback recebido dos instrutores/orientadores relativamente às tarefas e ao avanço no curso" corroborando com Tinto (1973) que afirma em seu modelo que, se o envolvimento com o curso e com a instituição for frágil, a probabilidade de o estudante abandonar o curso aumenta. No curso estudado, o contato que os alunos têm com a instituição (com a UnB) acontece principalmente por meio do contato com os tutores a distância.

A2 - "Tive dificuldades por falta de acompanhamento. O tutor a distância sumia, não dava apoio."

A13 - "Senti falta de contato presencial com o professor da disciplina, não com os colegas mas com o tutor a distância, queria ter mais contato presencial com ele."

\section{Tabela 29 - Questão 11 do questionário}

\begin{tabular}{|c|c|c|c|c|c|c|}
\hline Questão & Pergunta & Q.R & $\begin{array}{c}\text { Resp. } \\
\text { Mínima }\end{array}$ & $\begin{array}{c}\text { Resp. } \\
\text { Máxima }\end{array}$ & Média & $\begin{array}{c}\text { Desvio } \\
\text { Padrão }\end{array}$ \\
\hline 11 & $\begin{array}{c}\text { Sentiu-se apoiado pelo } \\
\text { tutor presencial? }\end{array}$ & 25 & 1 & 5 & 3,76 & 1,42244 \\
\hline
\end{tabular}

Fonte: Elaboração da autora (2015).

Essa questão é também é muito importante na pesquisa, pois o tutor presencial é o profissional docente que acompanha de perto os alunos, ele os atende no polo de apoio presencial, ficando lá a disposição dos alunos $20 \mathrm{~h}$ por semana. Com uma média de 3,76 de resposta, a maioria dos alunos apontou que se sentiram apoiados pelo tutor presencial enquanto que a frequência negativa apontou 
que 4 alunos (16\%) não se sentiram apoiados pelo tutor presencial e 7 alunos (28\%) disseram que às vezes se sentiram apoiados.

Os resultados sobre a tutoria a distância e presencial para além de Moore (2010) e Tinto (1973), corrobora com Xenos, Pierrakeas e Pintelas (2002) que aponta que problemas com o tutor leva a desistência dos alunos. Problemas com o fato do tutor não conseguir ajudar o suficiente para que o aluno entenda o material de estudos e a execução das tarefas; problemas de comunicação, lentidão nas respostas das atividades, o tutor não passar segurança de que sabe o conteúdo o suficiente para ensiná-los e encontros presenciais mal sucedidos são indicados como causadores de desistência.

A2 - "O tutor presencial tentava ajudar, mas não sabia quase nada."

A17 - "Falta de organização do curso, o tutor presencial era despreparado e não sabia ajudar os alunos."

A18 - "Falta de preparo do tutor presencial, falta de preparo de quem trabalhava no polo."

Tabela 30 - Questão 12 do questionário

\begin{tabular}{|c|c|c|c|c|c|c|}
\hline Questão & Pergunta & Q.R & $\begin{array}{c}\text { Resp. } \\
\text { Mínima }\end{array}$ & $\begin{array}{c}\text { Resp. } \\
\text { Máxima }\end{array}$ & Média & $\begin{array}{c}\text { Desvio } \\
\text { Padrão }\end{array}$ \\
\hline 12 & $\begin{array}{c}\text { Você teve problemas de } \\
\text { relacionamento com o } \\
\text { Coordenador do Polo? }\end{array}$ & 25 & 1 & 5 & 4,72 & 0,89069 \\
\hline
\end{tabular}

Fonte: Elaboração da autora (2015).

$\mathrm{Na}$ questão 12 a maioria dos alunos disse que não tiveram problemas com o Coordenador do Polo. A frequência apresenta somente 1 aluno que disse que sempre teve problemas com o coordenador.

A11 - "O motivo principal era porque não conseguia conciliar o trabalho com as atividades presenciais do curso. Eu não podia ir ao polo aos sábados para fazer as provas e o pessoal do polo não flexibilizava o horário para que eu fizesse as provas em outro horário. Além disso, às vezes conseguia folga no trabalho para ir e chegava no polo e a atividade não acontecia, perdia o dia de trabalho e não acontecia a atividade prevista no polo. Como e chefe de família não podia abrir mão do trabalho para estudar e pela falta de flexibilidade do curso desisti." 
Tabela 31 - Questão 13 do questionário

\begin{tabular}{|c|c|c|c|c|c|c|}
\hline Questão & Pergunta & Q.R & $\begin{array}{c}\text { Resp. } \\
\text { Mínima }\end{array}$ & $\begin{array}{c}\text { Resp. } \\
\text { Máxima }\end{array}$ & Média & $\begin{array}{c}\text { Desvio } \\
\text { Padrão }\end{array}$ \\
\hline 13 & $\begin{array}{c}\text { Sentiu falta do contato } \\
\text { virtual com outros alunos? } \\
\text { (e-mail, chat, fórum, etc) }\end{array}$ & 25 & 1 & 5 & 3,36 & 1,62993 \\
\hline
\end{tabular}

Fonte: Elaboração da autora (2015).

Essa questão apontou uma média de 3,36 e um desvio-padrão alto, de 1,62. A frequência negativa esclarece que 7 alunos, ou seja $28 \%$ dos alunos que responderam à pesquisa sentiram falta do contato virtual com outros alunos e que 6 alunos (24\%) sentiam as vezes. Tinto (1973) aponta que a integração do estudante no ambiente universitário influencia na continuidade do curso, que integração do estudante em sistemas sociais os levam a ter novas metas, novos objetivos e diferentes graus de compromisso com a instituição.

Nesse caso o fato de os alunos não se sentirem integrados aos colegas virtualmente influenciou na decisão de evadir.

A6 - "A turma era muito desunida, vários colegas achavam que sabiam tocar muito e não tinham paciência e nem interagiam com os que sabiam menos."

\section{Tabela 32 - Questão 13 do questionário}

\begin{tabular}{|c|c|c|c|c|c|c|}
\hline Questão & Pergunta & Q.R & $\begin{array}{c}\text { Resp. } \\
\text { Mínima }\end{array}$ & $\begin{array}{c}\text { Resp. } \\
\text { Máxima }\end{array}$ & Média & $\begin{array}{c}\text { Desvio } \\
\text { Padrão }\end{array}$ \\
\hline 14 & $\begin{array}{c}\text { Achou o conteúdo das } \\
\text { disciplinas difícil? }\end{array}$ & 25 & 1 & 5 & 3,44 & 1,15758 \\
\hline
\end{tabular}

Fonte: Elaboração da autora (2015).

A questão 14 indagou se o conteúdo das disciplinas era difícil e como resposta obteve uma média de $3,44 \mathrm{com} 1,5$ de desvio-padrão. A frequência mostrou que 4 alunos (16\%) sempre acharam o conteúdo das disciplinas difícil e que 12 alunos(48\%) achavam difícil às vezes, mostrando que essa dificuldade esteve presente no percurso da maioria dos alunos. A questão 30 apresentou uma categoria chamada problemas com disciplinas em qual 9 alunos disseram ter dificuldades na realização das disciplinas.

A4 - "Sugiro que o curso tenha menos disciplinas ao mesmo tempo, a carga horária é muito grande." 
Tabela 33 - Questão 15 do questionário

\begin{tabular}{|c|c|c|c|c|c|c|}
\hline Questão & Pergunta & Q.R & $\begin{array}{c}\text { Resp. } \\
\text { Mínima }\end{array}$ & $\begin{array}{c}\text { Resp. } \\
\text { Máxima }\end{array}$ & Média & $\begin{array}{c}\text { Desvio } \\
\text { Padrão }\end{array}$ \\
\hline 15 & $\begin{array}{c}\text { Você teve dificuldades de } \\
\text { realizar as atividades das } \\
\text { disciplinas do Núcleo de } \\
\begin{array}{c}\text { Formação Musical? (Ex: } \\
\text { Percepcão e Estruturação } \\
\text { Musical, Instrumento Principal } \\
\text { e optativo, etc) }\end{array}\end{array}$ & 25 & 1 & 5 & 3,64 & 1,52425 \\
\hline
\end{tabular}

Fonte: Elaboração da autora (2015).

Relacionada aos objetivos específicos, essa questão apresentou uma média de resposta de 3,64 com desvio-padrão de 1,52. A frequência negativa foi de 5 alunos (20\%) e 7 alunos (28\%) tiveram dificuldades em algum momento do curso, sendo assim, metade dos respondentes demonstraram ter dificuldades de realizar as atividades relacionadas as práticas musicais em algum momento do curso.

A7 - "Teve outra questão... eu entendo de música, e tinha dificuldades para resolver algumas questões, imagine como ficavam quem não entendia quase nada?"

A16 - "Excesso de tarefas na plataforma, dificuldade de conciliar com o trabalho, o tempo para aprender o instrumento era pouco, excesso de disciplinas por semestre, excesso de atividades por disciplina, falta de apoio musical, falta de musicalidade no curso,"

\section{Tabela 34 - Questão 16 do questionário}

\begin{tabular}{|c|c|c|c|c|c|c|}
\hline Questão & Pergunta & Q.R & $\begin{array}{c}\text { Resp. } \\
\text { Mínima }\end{array}$ & $\begin{array}{c}\text { Resp. } \\
\text { Máxima }\end{array}$ & Média & $\begin{array}{c}\text { Desvio } \\
\text { Padrão }\end{array}$ \\
\hline 16 & $\begin{array}{c}\text { Teve dificuldades de realizar } \\
\text { as atividades das disciplinas } \\
\text { do Núcleo de Educação } \\
\text { Musical? (Ex: Prática de } \\
\text { Ensino e Aprendizagem } \\
\text { Musical, Introdução a } \\
\text { Pesquisa em Música, etc) }\end{array}$ & 25 & 1 & 5 & 3,48 & 1,38804 \\
\hline
\end{tabular}

Fonte: Elaboração da autora (2015).

A questão 16 está diretamente relacionada aos objetivos específicos e apresentou que a média de resposta foi de 3,48 com desvio-padrão de 1,38. A frequência negativa corresponde a $24 \%$ dos alunos, ou seja, 6 alunos relataram dificuldades ao realizar as atividades das disciplinas do Núcleo de Educação Musical e outros 6 alunos relataram ter dificuldades às vezes, mostrando que metade dos respondentes tiveram dificuldades com as disciplinas do Núcleo de Educação Musical em algum momento do curso. 
A16 - "Excesso de tarefas na plataforma, dificuldade de conciliar com o trabalho, o tempo para aprender o instrumento era pouco, excesso de disciplinas por semestre, excesso de atividades por disciplina, falta de apoio musical, falta de musicalidade no curso."

Tabela 35 - Questão 17 do questionário

\begin{tabular}{|c|c|c|c|c|c|c|}
\hline Questão & Pergunta & Q.R & $\begin{array}{c}\text { Resp. } \\
\text { Mínima }\end{array}$ & $\begin{array}{c}\text { Resp. } \\
\text { Máxima }\end{array}$ & Média & $\begin{array}{c}\text { Desvio } \\
\text { Padrão }\end{array}$ \\
\hline 17 & $\begin{array}{c}\text { Você teve dificuldades de } \\
\text { realizar as atividades das } \\
\text { disciplinas do Núcleo de } \\
\text { Fundamentação Pedagógica? } \\
\text { (Ex: Leitura e Produção de } \\
\text { Texto, Teoria da Arte, etc.) }\end{array}$ & 25 & 1 & 5 & 3,44 & 1,63503 \\
\hline
\end{tabular}

Fonte: Elaboração da autora (2015).

Ao serem indagados sobre as disciplinas do Núcleo de Fundamentação Pedagógica, os alunos apontaram uma média de resposta de 3,44 com desviopadrão de 1,63. A frequência negativa apontou que 7 alunos (28\%) tiveram dificuldades de realizar essas disciplinas e que outros 4 alunos (16\%) tiveram dificuldades às vezes, indicando que $44 \%$ dos alunos tiveram dificuldades de realizar as atividades das disciplinas do Núcleo de Fundamentação Pedagógica em algum momento do curso.

Tabela 36 - Questão 18 do questionário

\begin{tabular}{|c|c|c|c|c|c|c|}
\hline Questão & Pergunta & Q.R & $\begin{array}{c}\text { Resp. } \\
\text { Mínima }\end{array}$ & $\begin{array}{c}\text { Resp. } \\
\text { Máxima }\end{array}$ & Média & $\begin{array}{c}\text { Desvio } \\
\text { Padrão }\end{array}$ \\
\hline 18 & $\begin{array}{c}\text { Achou difícil obter boas } \\
\text { notas nas avaliações de } \\
\text { aprendizagem? }\end{array}$ & 25 & 1 & 5 & 3,24 & 1,61452 \\
\hline
\end{tabular}

Fonte: Elaboração da autora (2015).

A questão 18 apontou que $32 \%$ dos alunos acharam difícil obter boas notas nas avaliações de aprendizagem, que $24 \%$ achavam difícil às vezes, mostrando que $56 \%$ dos respondentes acharam difícil obter boas notas nas avaliações em algum momento do curso.

Xenos, Pierrakeas e Pintelas (2002) discutem que os fatores internos como nível os de motivação podem ser usados como preditores de evasão. E, nesse caso, obter notas ruins nas avaliações pode gerar desmotivação.

A22 - "A quantidade de vídeos exigidos no encontro presencial era grande, a estrutura pedagógica e metodológica do curso a distância era desmotivadora [...]. Não conseguia ter o rendimento almejado em nível de conhecimento." 
Tabela 37 - Questão 19 do questionário

\begin{tabular}{|c|c|c|c|c|c|c|}
\hline Questão & Pergunta & Q.R & $\begin{array}{c}\text { Resp. } \\
\text { Mínima }\end{array}$ & $\begin{array}{c}\text { Resp. } \\
\text { Máxima }\end{array}$ & Média & $\begin{array}{c}\text { Desvio } \\
\text { Padrão }\end{array}$ \\
\hline 19 & $\begin{array}{c}\text { Você sentiu falta de } \\
\text { aulas presenciais? }\end{array}$ & 25 & 1 & 5 & 1,76 & 1,3 \\
\hline
\end{tabular}

Fonte: Elaboração da autora (2015).

As respostas da questão 19 apresentaram uma média de 1,76 e desviopadrão de 1,3 .

Essa foi a questão com segundo maior percentual negativo deste questionário, de 25 alunos, 19 alunos (76\%) disseram que sentiram falta de aulas presenciais, e 3 alunos (12\%) sentiu falta às vezes, mostrando que $88 \%$ dos respondentes sentiram falta de aulas presenciais no curso.

Estes dados corroboram com a teoria de Tinto (1973) que afirma que a integração do estudante no ambiente universitário influencia na continuidade do curso. Caso não haja integração universitária nos sistemas sociais da faculdade a chance do aluno desistir aumenta. Afirma ainda que quanto maior a integração do estudante com as atividades universitárias, maior será seu compromisso com a instituição e com a meta de concluir o curso. Se o envolvimento com o curso e com a instituição for frágil, a probabilidade de o estudante abandonar o curso aumenta.

No sistema UAB o espaço destinado aos encontros presenciais é o polo e de acordo com a o Decreto № 5.622 a obrigatoriedade de momentos presenciais existe para 4 situações: avaliações de estudantes; estágios obrigatórios, quando previstos na legislação pertinente; defesa de trabalhos de conclusão de curso, quando previstos na legislação pertinente; e atividades relacionadas a laboratórios de ensino, quando for o caso.

Os alunos no início do curso são esclarecidos em relação à quantidade de encontros presenciais, esse desejo por mais aulas presenciais pode indicar que os alunos tiveram dificuldades em estudar por meio da modalidade a distância.

A22 - "Continuo cursando música num curso presencial da Universidade Estadual de Goiás."

Tabela 38 - Questão 20 do questionário

\begin{tabular}{|c|c|c|c|c|c|c|}
\hline Questão & Pergunta & Q.R & $\begin{array}{c}\text { Resp. } \\
\text { Mínima }\end{array}$ & $\begin{array}{c}\text { Resp. } \\
\text { Máxima }\end{array}$ & Média & $\begin{array}{c}\text { Desvio } \\
\text { Padrão }\end{array}$ \\
\hline 20 & $\begin{array}{l}\text { Sentiu falta da presença } \\
\text { física de outros alunos? }\end{array}$ & 25 & 1 & 5 & 2,96 & 1,56738 \\
\hline
\end{tabular}

Fonte: Elaboração da autora (2015). 
Essa questão apontou que a média de resposta foi de 2,96 com desviopadrão de 1,56, o que sugere que a maioria dos alunos sentiu falta da presença física de outros alunos. A frequência negativa mostrou que 8 alunos (32\%) sentiram falta da presença física de outros alunos e que 8 alunos (32\%) sentiram falta as vezes.

Esse resultado apresenta indícios como na questão anterior e na questão 5 de que parte dos alunos não tinham perfil para estudar a distância, tinham dificuldades em interagir a distância, sentiam necessidade de estar em contato presencial com o professor e os colegas, alunos não se sentiam confortáveis em estudar sozinhos.

A4 - "Me senti sozinha para fazer as atividades em grupo, as gravações musicais, a solidão, o fato de ser a única aluna de [...] me atrapalhou, acho que se tivesse outros colegas na cidade teria mais facilidade."

A5 - "Me sentia muito sozinho para realizar as atividades em grupo. Apesar de morar em [...], morava num bairro muito afastado dos outros colegas e não conseguia organizar com eles horários compatíveis para fazer as gravações, atividades em grupo para as disciplinas."

Tabela 39 - Questão 21 do questionário

\begin{tabular}{|c|c|c|c|c|c|c|}
\hline Questão & Pergunta & Q.R & $\begin{array}{c}\text { Resp. } \\
\text { Mínima }\end{array}$ & $\begin{array}{c}\text { Resp. } \\
\text { Máxima }\end{array}$ & Média & $\begin{array}{c}\text { Desvio } \\
\text { Padrão }\end{array}$ \\
\hline 21 & $\begin{array}{c}\text { Sentiu-se estimulado a } \\
\text { participar das atividades } \\
\text { em grupo? }\end{array}$ & 25 & 1 & 5 & 3,84 & 1,49108 \\
\hline
\end{tabular}

Fonte: Elaboração da autora (2015).

Com média de resposta de 3,84 a questão 21 mostrou que a maioria dos alunos sentiram-se estimulados a participarem das atividades em grupo. A frequência negativa apresenta que 6 alunos (24\%) não se sentiram estimulados.

Tabela 40 - Questão 22 do questionário

\begin{tabular}{|c|c|c|c|c|c|c|}
\hline Questão & Pergunta & Q.R & $\begin{array}{c}\text { Resp. } \\
\text { Mínima }\end{array}$ & $\begin{array}{c}\text { Resp. } \\
\text { Máxima }\end{array}$ & Média & $\begin{array}{c}\text { Desvio } \\
\text { Padrão }\end{array}$ \\
\hline 22 & $\begin{array}{c}\text { Você foi incentivado pela } \\
\text { sua família a realizar o } \\
\text { curso? }\end{array}$ & 25 & 1 & 5 & 4,4 & 1,35401 \\
\hline
\end{tabular}

Fonte: Elaboração da autora (2015).

A questão 22 aponta que a maioria dos respondentes foram incentivados pela família a realizarem o curso. A frequência mínima apresentou 3 alunos que não foram incentivados pela família. 
A pesquisa de Xenos (2002) apresentou relevância nesse sentindo, em que motivos familiares foram responsáveis por $17,8 \%$ evasão, que não teve tanto impacto nesta pesquisa.

\section{Tabela 41 - Questão 23 do questionário}

\begin{tabular}{|c|c|c|c|c|c|c|}
\hline Questão & Pergunta & Q.R & $\begin{array}{c}\text { Resp. } \\
\text { Mínima }\end{array}$ & $\begin{array}{c}\text { Resp. } \\
\text { Máxima }\end{array}$ & Média & $\begin{array}{c}\text { Desvio } \\
\text { Padrão }\end{array}$ \\
\hline 23 & $\begin{array}{c}\text { Teve dificuldades em } \\
\text { conciliar estudos e trabalho } \\
\text { durante o curso? }\end{array}$ & 25 & 1 & 5 & 3,28 & 1,2083 \\
\hline
\end{tabular}

Fonte: Elaboração da autora (2015).

Essa questão foi a mais expressiva como motivadora de evasão desta pesquisa, em que $80 \%$ dos alunos apontaram a falta de tempo como determinante para sua desistência. A frequência negativa mostrou que 20 alunos tiveram dificuldades em conciliar estudos e trabalho sempre ou quase sempre e que 3 tiveram dificuldades às vezes em conciliar estudos e trabalho durante o curso. $O$ perfil dos alunos aponta que grande parte dos alunos trabalhavam 40h semanais ou mais.

A4 - "Problema de conciliar o tempo por causa do trabalho."

A11 - "O motivo principal era porque não conseguia conciliar o trabalho com as atividades presenciais do curso."

A14 - "Tive dificuldade de conciliar o trabalho."

A16 - "Dificuldade de conciliar o curso com o trabalho."

A18 - "Dificuldades de conciliar com o trabalho."

A23 - "Fiquei chateada em desistir, mas às vezes viajo a trabalho e então não dava tempo e passava final de semana realizando tarefas."

Esses dados corroboram com a pesquisa de Xenos, Pierrakeas e Pintelas (2002) na qual $62,1 \%$ dos alunos apontaram os motivos profissionais como sendo o motivo de sua evasão, a maioria deles apontaram os motivos profissionais como causadora de evasão.

\section{Tabela 42 - Questão 24 do questionário}

\begin{tabular}{|c|c|c|c|c|c|c|}
\hline Questão & Pergunta & Q.R & $\begin{array}{c}\text { Resp. } \\
\text { Mínima }\end{array}$ & $\begin{array}{c}\text { Resp. } \\
\text { Máxima }\end{array}$ & Média & $\begin{array}{c}\text { Desvio } \\
\text { Padrão }\end{array}$ \\
\hline 24 & $\begin{array}{c}\text { Você se organizou } \\
\text { financeiramente para } \\
\text { frequentar os encontros } \\
\text { presenciais? }\end{array}$ & 25 & 3 & 5 & 4,64 & 0,7 \\
\hline
\end{tabular}

Fonte: Elaboração da autora (2015). 
Com média 4,64 e desvio-padrão 0,7, essa questão indica que a maioria dos alunos demonstrou organização financeira para frequentar os encontros presenciais.

Tabela 43 - Questão 25 do questionário

\begin{tabular}{|c|c|c|c|c|c|c|}
\hline Questão & Pergunta & Q.R & $\begin{array}{c}\text { Resp. } \\
\text { Mínima }\end{array}$ & $\begin{array}{c}\text { Résp. } \\
\text { Máxima }\end{array}$ & Média & $\begin{array}{c}\text { Desvio } \\
\text { Padrão }\end{array}$ \\
\hline 25 & $\begin{array}{c}\text { Você procurou conciliar sua } \\
\text { participação no curso com } \\
\text { seus compromissos } \\
\text { familiares? }\end{array}$ & 25 & 1 & 5 & 4,12 & 1,33292 \\
\hline
\end{tabular}

Fonte: Elaboração da autora (2015).

Os alunos demonstraram em sua maioria ter conseguido conciliar sua participação no curso com seus compromissos familiares.

Tabela 44 - Questão 26 do questionário

\begin{tabular}{|c|c|c|c|c|c|c|}
\hline Questão & Pergunta & Q.R & $\begin{array}{c}\text { Resp. } \\
\text { Mínima }\end{array}$ & $\begin{array}{c}\text { Resp. } \\
\text { Máxima }\end{array}$ & Média & $\begin{array}{c}\text { Desvio } \\
\text { Padrão }\end{array}$ \\
\hline 26 & $\begin{array}{c}\text { Algum problema de } \\
\text { saúde te impediu de } \\
\text { realizar o curso? }\end{array}$ & 25 & 1 & 5 & 4,04 & 1,56738 \\
\hline
\end{tabular}

Fonte: Elaboração da autora (2015).

A questão 26 apontou que 5 alunos (20\%) tiveram algum problema de saúde como impedimento para realizar o curso

A9 - "Falta de concentração e ansiedade por motivos de depressão."

Tabela 45 - Questão 26 do questionário

\begin{tabular}{|c|c|c|c|c|c|c|}
\hline Questão & Pergunta & Q.R & $\begin{array}{c}\text { Resp. } \\
\text { Mínima }\end{array}$ & $\begin{array}{c}\text { Resp. } \\
\text { Máxima }\end{array}$ & Média & $\begin{array}{c}\text { Desvio } \\
\text { Padrão }\end{array}$ \\
\hline 27 & $\begin{array}{c}\text { O tempo determinado para } \\
\text { você realizar as atividades } \\
\text { das disciplinas foi } \\
\text { suficiente? }\end{array}$ & 25 & 1 & 5 & 2,52 & 1,55778 \\
\hline
\end{tabular}

Fonte: Elaboração da autora (2015).

Esta questão relacionada ao tempo dividiu a opinião dos alunos, a média de resposta foi de 2,52 com desvio-padrão de 1,55. A frequência negativa mostrou que 15 alunos (60\%) acharam o tempo insuficiente e outros 3 alunos (12\%) acharam que não foi suficiente às vezes.

A7 - "A questão é a seguinte, resumindo bem, a plataforma quase nunca funcionava direito e para algumas atividades (aparentemente simples) o tempo para se fazê-las era curto." 
Tabela 46 - Questão 27 do questionário

\begin{tabular}{|c|c|c|c|c|c|c|}
\hline Questão & Pergunta & Q.R & $\begin{array}{c}\text { Resp. } \\
\text { Mínima }\end{array}$ & $\begin{array}{c}\text { Resp. } \\
\text { Máxima }\end{array}$ & Média & $\begin{array}{c}\text { Desvio } \\
\text { Padrão }\end{array}$ \\
\hline 28 & $\begin{array}{c}\text { Sentiu-se apoiado pelo } \\
\text { corpo técnico- } \\
\text { administrativo do curso? }\end{array}$ & 25 & 1 & 5 & 3,8 & 1,55456 \\
\hline
\end{tabular}

Fonte: Elaboração da autora (2015).

Nessa questão, a média de resposta foi de 3,8 com desvio-padrão de 1,55. A frequência mínima apontou que 5 alunos (20\%) não se sentiram apoiados pelo corpo técnico-administrativo do curso.

A14 - "Tive dificuldade de conciliar o trabalho, pedi trancamento e o pessoal do polo fez a documentação toda errada, não dava as informações corretas. Pedi reintegração, consegui, mas o curso me colocou reintegrado no meio do semestre com todas as atividades em curso. Eu já tinha conseguido mudar o esquema no horário de trabalho, mas não consegui acompanhar porque estava no meio do semestre, as atividades das disciplinas já estavam pela metade, por isso desisti de vez. Sou músico desde criança, agrônomo e queria continuar estudando música por hobby."

\section{Tabela 47 - Questão 29 do questionário}

\begin{tabular}{|c|c|c|c|c|c|c|}
\hline Questão & Pergunta & Q.R & $\begin{array}{c}\text { Resp. } \\
\text { Mínima }\end{array}$ & $\begin{array}{c}\text { Resp. } \\
\text { Máxima }\end{array}$ & Média & $\begin{array}{c}\text { Desvio } \\
\text { Padrão }\end{array}$ \\
\hline & $\begin{array}{c}\text { Você teve dificuldades de } \\
\text { acompanhar as atividades de } \\
\text { formação musical? (Ex.: } \\
\text { aprender tocar os } \\
\text { instrumentos; realizar } \\
\text { atividades de percepção e } \\
\text { criação musical)? }\end{array}$ & 25 & 1 & 5 & 3,64 & 1,52425 \\
\hline
\end{tabular}

Fonte: Elaboração da autora (2015).

Para confirmar a questão 15 que trata das especificidades do curso de música e justificar o objetivo específico que procura identificar se há relação entre a especificidade do curso de música e a evasão, essa questão apontou que a maioria dos alunos, 72,8\% não apresentou dificuldades de acompanhar as atividades de formação musical e que 27,2\% apresentaram dificuldades, apontando que as dificuldades com especificidade da música dentro do curso não tiveram uma relação relevante com a evasão no curso. 


\subsubsection{Análise de Conteúdo}

A última questão foi discursiva, na que os alunos tiveram a oportunidade de expressar qual foi o motivo mais relevante sob o seu ponto de vista para que desistisse do curso.

Foi feita uma categorização das respostas nas quais apareceram alguns fatores significativos. Esta categorização está baseada na quantidade de repetições de fatores causadores de evasão apontados pelos alunos na resposta da questão 30 do questionário: "Se você teve outros motivos que o levou a desistir do curso, por gentileza, apresente-os:". Na tabela 48 se encontram as categorias e a quantidade de vezes que ela foi citada nas respostas dos alunos.

Tabela 48 - Categorização da questão 30

\begin{tabular}{l|c}
\hline \multicolumn{2}{c}{ Categorização } \\
\hline Categoria & Incidência \\
\hline Falta de Tempo & 11 \\
\hline Problemas com Disciplinas & 9 \\
\hline Trabalho & 9 \\
\hline Polo & 6 \\
\hline Saúde & 6 \\
\hline UnB & 5 \\
\hline Família & 5 \\
\hline Problemas com a Plataforma & 4 \\
\hline Outro Curso & 4 \\
\hline Modalidade & 3 \\
\hline Distância dos colegas & 3 \\
\hline Tutor a Distância & 3 \\
\hline Tutor Presencial & 3 \\
\hline Internet no polo & 3 \\
\hline Fonte: Elaboração da autora (2015). &
\end{tabular}

Foi feito um agrupamento de questões de acordo com a repetição do fator. A categoria falta de tempo foi a que mais apareceu nessa análise. Em seguida, os problemas com disciplinas foram relatados como motivo de desistência, os alunos reclamaram que a quantidade de atividades dentro de cada disciplina é grande e que são muitas disciplinas ao mesmo tempo, acabam não conseguindo acompanhar. 
Dificuldades em conciliar estudos e trabalho apareceram como fortes indicadores de evasão e como foi visto nos dados de perfil, a maioria dos alunos trabalham 40 horas ou mais.

Uma questão que pode ser considerada como sugestão de resolução do problema é a redução de carga horária do curso, pois os indicadores a respeito da falta de tempo dos alunos e a quantidade de atividades dentro de cada disciplina podem estar relacionados a quantidade de horas do curso de Licenciatura em Música da UnB que tem 215 horas a mais que o mínimo exigido por lei para realização do curso. A resolução do Conselho Nacional de Educação / Conselho Pleno CNE/CP 2, de 19 de fevereiro de 2002, em seu artigo 1ํinstitui a duração e a carga horária dos cursos de licenciatura, de graduação plena, de formação de professores da Educação Básica em nível superior em 2800 (duas mil e oitocentas) horas. O curso pesquisado atua com 3015 (três mil e quinze) horas.

Problemas, como desorganização do polo e falta de internet nas suas dependências, foram relatados como indicadores de evasão. Os alunos reclamaram que precisavam da internet do polo para cursar a licenciatura, mas que o local estava sempre sem internet e que as atividades passavam do prazo de entrega. Houve reclamações quanto a organização administrativa e sobre a falta de informação dadas aos alunos. Que aulas são marcadas, os alunos viajam e quando chegam ao polo o mesmo se encontra fechado.

A15 - "Desorganização do curso, da UnB e do polo. Por ser um curso semipresencial eles não organizavam os encontros presencias, os alunos acabavam tendo que ir ao polo todos os dias por causa das atividades. A internet do polo não funcionava, o polo não tinha estrutura, a plataforma não funcionava, várias vezes marcavam para os alunos irem ao polo e acabava não acontecendo a atividade. Nós perdíamos o tempo, ao invés de ficar com a família ou trabalhar em outras coisas, perdíamos esse tempo."

Moore (2010) indica a assistência administrativa dada aos alunos como ponto importante no conjunto de ações que devem ser desenvolvidas para dar apoio ao aluno de educação a distância:

(...) no caso de um aluno que não estuda no campus, toda interação pode ocorrer por email ou telefone. Os alunos muitas vezes possuem dificuldade para identificar e contatar a pessoa certa com quem conversar (especialmente nas grandes instituições) e podem ficar muito frustrados. $\mathrm{O}$ ideal é que os alunos de programas de educação a distância conheçam uma única pessoa que podem contatar para todos os problemas 
administrativos. De maneira geral, todas as exigências e os procedimentos administrativos devem ser descritos em um manual do aluno na página da web que os alunos recebem no início de um curso ou quando se matriculam na instituição. (MOORE, 2010, p. 195)

Problemas de saúde foram motivos de evasão para seis alunos que relataram depressão e doenças de membros da família. Os alunos que tiveram depressão e tentaram reintegração no curso, mas não conseguiram.

Esse dado corrobora com Xenos, Pierrakeas e Pintelas (2002) que discutem que a influência dos fatores relacionados a percepção dos alunos em relação às dificuldades próprias para realização do curso; e os seus níveis de motivação e de persistência em relação ao curso podem gerar evasão. Em sua pesquisa 9,5\% dos alunos evadiram por problemas de saúde.

A8 - "Tive depressão e por isso não consegui continuar o curso. Quando eu tentei voltar os colegas estavam muito a frente e não consegui acompanhar."

Problemas com a UnB foram citados por não entenderem as regras da universidade e por serem mal informados sobre as mesmas regras. Aqui pode ser retomada a questão do apoio ao aluno que deve ser exercida com maior proximidade.

A categoria família é apontada por 5 alunos como motivo de desistência. Houve doenças e perda de entes queridos o que proporcionou a desestabilidade desses alunos corroborando com Xenos, Pierrakeas e Pintelas (2002) que aponta motivos familiares e de saúde como grandes causadores de evasão.

A19 - "Sofri um acidente de carro, perdi meu filho, e não tive condições emocionais de continuar o curso. Tive dificuldades para ir ao polo, pois perdi o carro no acidente. Entrei com pedido de reintegração, mas o curso não aceitou, indeferiu."

A21 - "Minha esposa engravidou, meu filho nasceu e tive que dar maior suporte a família e não consegui conciliar com o curso."

Problemas com a plataforma foram apontados como um motivo de evasão. Os alunos reclamaram que o tempo para fazer as atividades era pouco e que quando iam fazer a plataforma não funcionava, saia do ar e eles perdiam os prazos.

A7 - "A questão é a seguinte, resumindo bem, a plataforma quase nunca funcionava direito e para algumas atividades (aparentemente simples) o tempo para se fazê-las era curto. Acontecia, por exemplo, do portal não funcionar, e com isso eu perdia o dia, e quando funcionava o tempo da atividade já tinha se esgotado e com isso, eu perdia nota e ganhava uma falta (isso quando não tinha alguma prova 
surpresa). Penso da seguinte maneira, se eu faço uma faculdade pela internet, é por que não tenho tempo de fazer uma presencial, ou por falta de opção onde moro. No meu caso acabou sendo os dois. Agora veja, se eu não tenho tempo de fazer uma faculdade presencial, como vou ter tempo para ficar 4horas diárias na frente de um computador em um portal que não funciona?"

Dos 25 alunos que responderam ao questionário, quatro alunos resolveram trocar de curso por acreditarem que outras áreas eram mais promissoras profissionalmente, que teriam mais retorno financeiro. Tinto (1973), apresenta este fator como influenciador de evasão, pois a mudança do mercado de trabalho influencia nos objetivos profissionais do estudante, que por sua vez poderá reavaliar seus objetivos de formação profissional e querer mudar as metas. Caso isto aconteça, o estudante poderá abandonar o curso mesmo que tenha se integrado na instituição, que seria caracterizado como um abandono voluntário.

A12 - "O principal motivo foi o fato do mercado de trabalho não oferecer um retorno financeiro que eu almejava. Surgiu a oportunidade de fazer outro curso, o de direito, que acho que me dará mais retorno financeiro como profissional. Pretendo fazer algum curso de música como hobby futuramente."

A22 - "Eu cursava engenharia paralelamente ao curso de música e também trabalhava, quando os horários começaram a conflitar tive de escolher um curso para dar sequência, e como música não possui um retorno financeiro bom optei pela engenharia. No futuro eu voltaria para o curso de música, mas como hobby, não como profissão."

Dificuldades com a modalidade foi apontada por 3 alunos. Disseram que não se adaptaram. Dois destes alunos saíram da UnB e foram fazer Música na modalidade presencial em outras instituições.

Alguns alunos relataram a distância física dos colegas como motivador de evasão. Sentiam-se sozinhos, não conseguiam fazer as atividades em grupo e foram ficando desmotivados até desistir.

A5 - "Me sentia muito sozinho para realizar as atividades em grupo. Apesar de morar em Primavera do Leste, morava num bairro muito afastado dos outros colegas e não conseguia organizar com eles horários compatíveis para fazer as gravações, atividades em grupo para as disciplinas." 
Foram relatados alguns problemas com tutor a distância como sumiço da plataforma, falta de conhecimento musical e exposição dos alunos na hora de fazer correções nos fóruns.

Quanto ao tutor presencial foi relatado despreparo do mesmo, os alunos falaram que o tutor presencial era despreparado e não conseguia ajudar os alunos, faltava conhecimento musical e não conseguia orientar os alunos.

Internet no polo foi apontada como problema e além do polo, os alunos de Primavera do Leste reclamaram que a internet na região é muito ruim, então os alunos de um modo geral são prejudicados por falta de internet, por não conseguirem enviar as atividades a tempo.

A13 - "A internet era muito ruim, a rede de modo geral em Primavera do Leste é ruim, me sentia prejudicada por isso, a quantidade de atividades eram muitas para entregar no sábado a noite e pela diferença de fuso horário, nos tínhamos $1 \mathrm{~h}$ a menos que os demais colegas, dava meia noite o sistema fechava, mas em Primavera ainda era 23h."

Se relacionarmos esta pesquisa a pesquisa de Xenos, Pierrakeas e Pintelas (2002) percebe-se a incidência de fatores internos relacionados aos estudantes, percepção e lócus de controle causadores de evasão como falta de tempo (11), problemas de saúde (6), problemas com a família (5), outro curso (4) e distância dos colegas (3), totalizando 29 citações de fatores relacionados.

A pesquisa também aponta com indicadores de evasão fatores relacionados ao curso e os tutores como problemas com disciplinas (9), polo (6), UnB (5), problemas com a plataforma (4), modalidade (3), tutor a distância (3), tutor presencial (3) e internet no polo (3), totalizando 36 citações de fatores relacionados.

A pesquisa de Xenos, Pierrakeas e Pintelas (2002) também apresenta fatores relacionados a certas características demográficas dos alunos como causador de evasão que nesta pesquisa apareceu como problemas relacionados ao trabalho, com 9 citações dos alunos apontando este fator como responsável pela sua desistência.

O quadro a seguir apresenta o percentual (\%) de alunos que marcaram a frequência mínima (FR) apresentada no questionário, indicando de forma decrescente quais são as questões que mais causaram evasão de acordo com a amostra que respondeu o questionário. 
De acordo com as respostas dos alunos foram classificadas as frequências mínimas que esta sendo chamada de frequência negativa nesta análise. Somou-se a frequência 1 e 2; e calculou-se o percentual correspondente aquela resposta. Em seguida foi classificado em ordem decrescente para se visualizar quais foram os principais fatores de causaram evasão dos alunos de acordo com as respostas objetivas do questionário.

Quadro 5 - Principais causadores de evasão por questão

\begin{tabular}{|c|c|c|}
\hline Questão & FR & $\%$ \\
\hline 23. Teve dificuldades em conciliar estudos e trabalho durante o curso? & 20 & 80 \\
\hline 19. Você sentiu falta de aulas presenciais? & 19 & 76 \\
\hline $\begin{array}{l}\text { 27. O tempo determinado para você realizar as atividades das } \\
\text { disciplinas (não) foi suficiente? }\end{array}$ & 15 & 60 \\
\hline 7. Achou (difícil) realizar as disciplinas, sendo elas, à distância? & 10 & 40 \\
\hline 18. Achou difícil obter boas notas nas avaliações de aprendizagem? & 8 & 32 \\
\hline 20. Sentiu falta da presença física de outros alunos? & 8 & 32 \\
\hline $\begin{array}{l}\text { 1. O Curso de Licenciatura em Música (não) foi sua 1ª opção de curso } \\
\text { no vestibular? }\end{array}$ & 7 & 28 \\
\hline $\begin{array}{l}\text { 13. Sentiu falta do contato virtual com outros alunos? (e-mail, chat, } \\
\text { fórum, etc) }\end{array}$ & 7 & 28 \\
\hline $\begin{array}{l}\text { 17. Você teve dificuldades de realizar as atividades das disciplinas do } \\
\text { Núcleo de Fundamentação Pedagógica? (Ex: Leitura e Produção de } \\
\text { Texto, Teoria da Arte, etc.) }\end{array}$ & 7 & 28 \\
\hline 5. Sentiu-se (desconfortável) em estudar sozinho? & 6 & 24 \\
\hline $\begin{array}{l}\text { 16. Teve dificuldades de realizar as atividades das disciplinas do } \\
\text { Núcleo de Educação Musical? (Ex: Prática de Ensino e Aprendizagem } \\
\text { Musical, Introdução a Pesquisa em Música, etc) }\end{array}$ & 6 & 24 \\
\hline 21. Sentiu-se (desestimulado) a participar das atividades em grupo? & 6 & 24 \\
\hline $\begin{array}{l}\text { 9. Durante o curso teve dificuldades em utilizar os recursos } \\
\text { tecnológicos de informática (Internet, correio eletrônico, chat, fórum, } \\
\text { recursos da plataforma moodle, entre outros)? }\end{array}$ & 5 & 20 \\
\hline $\begin{array}{l}\text { 15. Você teve dificuldades de realizar as atividades das disciplinas do } \\
\text { Núcleo de Formação Musical? (Ex: Percepção e Estruturação Musical, } \\
\text { Instrumento Principal e optativo, etc) }\end{array}$ & 5 & 20 \\
\hline 26. Algum problema de saúde te impediu de realizar o curso? & 5 & 20 \\
\hline $\begin{array}{l}\text { 28. (Não) se sentiu apoiado pelo corpo técnico-administrativo do } \\
\text { curso? }\end{array}$ & 5 & 20 \\
\hline $\begin{array}{l}\text { 29. Você teve dificuldades de acompanhar as atividades de formação } \\
\text { musical? (Ex.: aprender tocar os instrumentos; realizar atividades de } \\
\text { percepção e criação musical)? }\end{array}$ & 5 & 20 \\
\hline 11. (Não) se sentiu apoiado pelo tutor presencial? & 4 & 16 \\
\hline 14. Achou o conteúdo das disciplinas difícil? & 4 & 16 \\
\hline $\begin{array}{l}\text { 6. Você (não) elaborou um plano de estudos com reserva de horários } \\
\text { para realizar as atividades do curso? }\end{array}$ & 3 & 12 \\
\hline 8. Teve dificuldades de acesso à computadores ou internet? & 3 & 12 \\
\hline 10. (Não) se sentiu apoiado pelo tutor/professor a distância? & 3 & 12 \\
\hline
\end{tabular}


Continuação do Quadro 5 - Principais causadores de evasão por questão 22. Você (não) foi incentivado pela sua família a realizar o curso? 25. Você (não) procurou conciliar sua participação no curso com seus compromissos familiares?

2. Você escolheu cursar Licenciatura em Música por falta de outras opções de curso?

3. Você (não) procurou ler os materiais que informavam sobre as características do curso de Licenciatura em Música, como prazos, atividades previstas e atuação profissional?

12. Você teve problemas de relacionamento com o Coordenador do Polo?

4. Você (não) tinha conhecimento de informática básica antes de iniciar o curso (ligar o computador, trabalhar com editor de textos, armazenar arquivos, entre outros)?

24. Você se organizou financeiramente para frequentar os encontros presenciais?

Fonte: Elaboração da autora (2015).

Ao se fazer uma comparação dos dados da análise de conteúdo com as questões do questionário apontadas como indicadores de evasão percebe-se a confirmação dos fatores causadores de evasão. Os dados indicam problemas relacionados a falta de tempo, dificuldades com fatores ligados a modalidade a distância como não ter aulas presenciais e falta da presença física de outros alunos; outro fator bastante citado foi a dificuldade para realização das disciplinas. 


\section{CAPÍTULO 5 - CONSIDERAÇÕES FINAIS}

Esta pesquisa foi iniciada pelo desejo de encontrar respostas sobre o que estaria causando a evasão dos alunos do curso de Licenciatura em Música a distância da UnB. A gestão do curso, composta por uma equipe de professores qualificados e entusiastas procurava entender o que estaria levando os alunos a desistirem do curso.

A proposta de pesquisa foi consolidada na aplicação de um survey para uma amostra de alunos evadidos por meio de um questionário aplicado via ligação telefônica e e-mail.

A amostra, composta por 53 alunos evadidos, foi escolhida de acordo com a atualidade dos dados de e-mail e telefone e por se aproximar da forma atual do currículo do curso. Obteve-se 25 respostas que corresponderam a $47 \%$ da amostra e foi com base nestas informações que se chegou às conclusões desta pesquisa.

Os objetivos procuravam identificar e analisar os fatores que causam evasão dos alunos do Curso de Licenciatura em Música a Distância da UnB, conhecer o perfil do aluno que abandona o curso e identificar se há relação entre a especificidade do curso de música e a evasão.

$\mathrm{Na}$ análise feita sobre os fatores que causam evasão dos alunos identificouse a falta de tempo como principal indicador de evasão, $80 \%$ dos alunos apontaram essa como sendo a principal causa de sua evasão. Eles apontaram a dificuldade de conciliar o tempo que precisavam dedicar ao curso com o trabalho e as demais atividades cotidianas.

Outro fator que se destacou como causador de evasão foram as dificuldades em lidar com as características de um curso a distância, apontaram dificuldades por não ter aulas presenciais, não se sentirem confortáveis em estudar sozinhos, falta da presença física e virtual com outros alunos, ou seja, sentiram falta do contato presencial com os colegas e não conseguiram interagir a distância com os mesmos. Este resultado corrobora com Tinto (1973) que aponta a dificuldade de interação social dentro da instituição como forte indicador de evasão.

As análises mostraram que dificuldades em concluir as disciplinas foi um dos principais causadores de evasão desta amostra. Indicadores como insuficiência do tempo determinado para realização das atividades das disciplinas, dificuldades para realizar as disciplinas a distância, dificuldade de obter boas notas nas avaliações de 
aprendizagem e dificuldades para realizar as atividades das disciplinas do Núcleo de Fundamentação Pedagógica contribuíram para este indicador de evasão do curso.

Esta pesquisa se propôs conhecer o perfil dos alunos do curso. Os dados mostraram que o aluno que evade do curso de Licenciatura em Música a distância da UnB é em sua maioria homens. A idade dos alunos foi classificada entre 20 e 40 anos, trabalham $40 \mathrm{~h}$ semanais ou mais. A quantidade de solteiros e casados é equilibrada e que a maioria dos estudantes que entrou no curso era proveniente diretamente do ensino médio, isto é, a maioria não tinha outra graduação.

Entre os objetivos desta pesquisa o que mais motivou a pesquisadora foi identificar se há relação entre a especificidade do curso de música e a evasão. Constatou-se que essa relação não foi grande influenciadora de evasão. Os alunos demonstraram que entraram no curso de Licenciatura em Música conscientes de que queriam estudar música, os dados demonstraram que a maioria dos alunos conhecia a área de atuação, que tinham facilidade em executar as atividades práticas das disciplinas e que tinham facilidade na realização das disciplinas de formação musical, demonstrando que as especificidades do curso de música tiveram baixa influência na evasão do curso.

A partir das análises apresentadas, concluo que esta pesquisa corrobora com outras pesquisas da área de EAD e no âmbito da educação a distância colabora para ampliar o escopo dos estudos com foco na evasão em cursos a distância, em especial abre um escopo de estudos sobre a evasão de cursos de Música à distância. Para a área de educação musical, a contribuição se dá pelo fato de se ter estudado evasão em um curso de Música a distância e por constatar que as especificidades de um curso de música não causam estranheza aos alunos, não são fortes indicadores de evasão.

Aponto para necessidade de novas pesquisas na área, especialmente que:

- Analisem criticamente ementas das disciplinas em relação às dificuldades apresentadas pelos alunos; que analisem a carga horária do curso e a quantidade de disciplinas por período;

- Avaliem a forma de seleção de novos alunos, tendo em vista a dificuldade apontada pelos alunos no decorrer do curso, considerando que $40 \%$ dos alunos afirmaram ter dificuldade em realizar as disciplinas. Nesse sentido, seria interessante pesquisar a possibilidade de adequação do nível de dificuldade do vestibular em relação à dificuldade das disciplinas ofertadas no 
curso.

- Estudem novas formas de apoio ao aluno, para que este se sinta amparado e motivado a concluir o curso. 


\section{REFERÊNCIAS}

ABED. Associação Brasileira de Educação a Distância. CensoEad.BR 2011/2012. Disponível em:

$<$ http://www.abed.org.br/censoead2013/CENSO EAD 2013 PORTUGUES.pdf Acesso: 05 fev. 2015.

. CONGRESSO DA ABED. Evasão na pós-graduação.

Disponível em:<www.abed.org.br/congresso2008/tc/552008112738PM.pdf>.

Acesso em 18 jun. 2013.

ALVES, João Roberto Moreira. A história da EAD no Brasil. In: LITTO, Frederic Michael; FORMIGA, Marcos Maciel(Org.). Educação a distância: o estado da arte. São Paulo: Pearson Education do Brasil, 2009.

ALMEIDA, Onília Cristina de Souza. Evasão em Cursos a Distância: validação de instrumento, fatores influenciadores e cronologia da desistência.

Disponível em: <http://bdtd.bce.unb.br/tedesimplificado/tde arquivos/65/TDE-200710-26T170707Z-1970/Publico/Dissert Onilia\%20Cristina.pdf>.

Acesso em: 18 jun. 2013.

CAPES. Edital UAB1. Disponível em:

$<$ http://www.uab.capes.gov.br/index.php?option=com content\&view=article\&id=11\&lt emid $=24>$.

Acesso: 05 fev. 2013.

Edital UAB2. Disponível em:

$<$ http://www.uab.capes.gov.br/index.php?option=com content\&view=article\&id=11\&lt emid $=24>$.

Acesso em: 05 fev. 2013.

. Histórico. Disponível em:

$<$ http://www.uab.capes.gov.br/index.php?option=com content\&view=article\&id=9:hist orico-\&catid=6:sobre\&ltemid=21>.

Acesso em: 05 fev. 2013.

SISUAB. Lista de Licenciaturas em Música ofertadas através do Sistema Universidade Aberta do Brasil. Disponível em:

http://www.uab.capes.gov.br/index.php?option=com wrapper\&view=wrapper\&ltemid $=12$ -

Acesso em: 13 dez. 2013

. SISUAB. Lista de 39 Licenciaturas em Português ofertadas através do

Sistema Universidade Aberta do Brasil. Disponível em:

$<$ http://www.uab.capes.gov.br/index.php?option=com wrapper\&view=wrapper\&ltemi $\underline{d=12>}$

Acesso em: 13 dez. 2013. 
DECRETO 5622, de 19 de dezembro de 2005. Disponível em: <http://www.planalto.gov.br/ccivil 03/ Ato2004-2006/2005/Decreto/D5622.htm> Acesso em: 04 fev. 2013.

DECRETO 5800, de 8 de junho de 2006. Disponível em : < http://www.planalto.gov.br/ccivil 03/ ato2004-2006/2006/decreto/d5800.htm> Acesso em: 04 fev. 2013.

ESTEVAM, Vicente. Ensino de música e evasão escolar em conservatórios de minas gerais: dois estudos de caso. Disponível em:

$<$ http://www.seer.unirio.br/index.php/simpom/article/viewFile/2488/1817>.

Acesso em 10 out. 2013.

FRANCO, Maria Laura Puglisi Barbosa. Análise de conteúdo. 3.ed.Brasília: Líber, 2008.

FREITAS, Henrique et al. O método de pesquisa survey. Revista de Administração, São Paulo, v. 35, n. 3, p.105-112, jul. 2000. Trimestral. Disponível em: <http://www.unisc.br/portal/upload/com_arquivo/o_metodo_de_pesquisa_survey.pdf>.

Acesso em: 20 out. 2013.

GIL. Antônio Carlos. Como elaborar projetos de pesquisa.4 ed. São paulo:Atlas, 2009.

Métodos e técnicas de pesquisa social. - 5. ed. São Paulo:Atlas, 2007.

LEI № 10.172, de 9 de janeiro de 2001. Disponível em: < http://www.planalto.gov.br/ccivil 03/leis/leis 2001/l10172.htm>

Acesso em: 10 fev. 2013.

L. QUICHERAT por F.R. dos Santos Saraiva. Novíssimo dicionário LATINOPORTUGUÊS - Etimologico, prosódico, histórico, geográfico, mitológico, biográfico, etc. Belo Horizonte - Rio de Janeiro: Livraria Garnier, 2000.

MARINS, Paulo Roberto Affonso; NARITA, Flávia Motoyama. Licenciatura em Música a Distância na UnB: planejamento e implementação. In: FERNANDES, Maria Lídia Bueno (Org.). Trajetórias das licenciaturas da UnB: EaD em foco. Brasília: Editora Universidade de Brasília, 2012.

MARTINS, L. R. R. Educação a Distância na Universidade de Brasília. Uma trajetória de janeiro de 1979 a junho de 2006. Dissertação (Mestrado em Educação) Faculdade de Educação, Universidade de Brasília, Brasília, 2006. (Não publicada).

MEC/ANDIFES/ABRUEM/SESU. Diplomação, retenção e evasão nos cursos de graduação em instituições de ensino superior públicas. Revista Avaliação, Campinas, SP, v., n. 2, p. 55-65, julho 1996.

MOORE, Michael G. Educação a distância: uma visão integrada/Michael G. Moore, Grey Kearsley; [traduação Roberto Galman]. São Paulo: Cengage Learning, 2008. 
. Educação a distância: uma visão integrada/Michael G. Moore, Grey Kearsley; [traduação Roberto Galman]. São Paulo: Cengage Learning, 2010.

NUNES, Ivônio Barros. A história da EAD no mundo. In: LITTO, Frederic Michael; FORMIGA, Marcos Maciel(Org.). Educação a distância: o estado da arte. São Paulo: Pearson Education do Brasil, 2009.

PASQUALI, Luiz. Teoria e métodos de medida em ciências do comportamento / organizado por Luiz Pasquali. - Brasília: Laboratório de Pesquisa em Avaliação e Medida / Instituto de Psicologia / UnB: INEP, 1996. 432p

Crítica, 1998.

Escala de locus de controle ELCO/TELEBRÁs. Psicologia: Reflexão e

PEREIRA, Eva Wairos; MORAES, Raquel de Almeida. História da educação a distância e os desafios na formação de professores no Brasil. In: SOUZA, Amaralina Miranda de; FIORENTINI, Leda Maria Rangearo; RODRIGUES, Maria Alexandra Militão (Org.). Educação Superior a distância: comunidade de trabalho e aprendizagem em rede (CTAR). Brasília: Universidade de Brasília, Faculdade de Educação, 2009.

PONTES, Elício Bezerra. A comunidade de Trabalho e Aprendizagem em Rede (CTAR) na Faculdade de Educação da UnB. In: SOUZA, Amaralina Miranda de; FIORENTINI, Leda Maria Rangearo; RODRIGUES, Maria Alexandra Militão (Org.). Educação Superior a distância: comunidade de trabalho e aprendizagem em rede (CTAR). Brasília: Universidade de Brasília, Faculdade de Educação, 2009.

PORTAL DA UAB/UnB.

Disponível em: <http://www.uab.unb.br/index.php/institucional/historico>>. Acesso em: 05 fev. 2013.

PORTARIA NORMATIVA №2, de 10 de janeiro de 2007 - Disponível em: $<$ http://www.uab.capes.gov.br/images/stories/downloads/legislacao/portaria normativ a 22007.pdf>

Acessado em: 06 mai. 2014

QUEIROZ, Lucilene Domingos. Um estudo sobre evasão escolar: para se pensar na inclusão escolar. Disponível em:

$<$ www.anped.org.br/reunioes/25/lucileidedomingosqueirozt13.rtf $>$.

Acesso em: 09 abr. 2013.

RIBEIRO, Girlene; ARAUJO, Jaíne. A Universidade Aberta do Brasil na Universidade de Brasília: análise de indicadores de avaliação e acompanhamento dos cursos. In: FERNANDES, Maria Lídia Bueno (Org.) Educação à distância no ensino superior: interlocução, interação e reflexão sobre UAB na UnB. Brasília: Editora Universidade de Brasília, 2012. 
SANTOS, P. C.; FIORENTINI, L. M. R.; Raquel. A história da Cátedra UNESCO de Educação a Distância da FE/UnB 2010 (Programa de Iniciação Científica 2009/2010). Disponível em:

$<$ http://buscatextual.cnpq.br/buscatextual/visualizacv.jsp?id=K4430097E5\#PP Boleti m\%20C\%C3\%A1tedra\%C2\%B4s\%20UNESCO\%20FE/UNB>.

Acesso em: 28 ago. 2010.

SILVA, Rosana Kelly Pedro. Método de pesquisa survey. Disponível em: <http://www.partes.com.br/2013/12/09/metodo-de-pesquisa-survey/\#.VP-Hdht0xIY>.

SOUZA, Amaralina Miranda de; FIORENTINI, Leda Maria Rangearo; RODRIGUES, Maria Alexandra Militão (Org.). Educação Superior a distância: comunidade de trabalho e aprendizagem em rede (CTAR). Brasília: Universidade de Brasília, Faculdade de Educação, 2009.

TINTO, Vincent. Dropout from Higher Education: A Theoretical Synthesis of Recent Research. Published by: American Educational Research Association, 1973.

UNB DIRETORIA DE ENSINO DE GRADUAÇÃO A DISTÂNCIA. Linha do tempo. Disponível em:

http://www.ead.unb.br/index.php/linha-do-tempo

Acesso em: 09 mar. 2015

Disponível em:

EVASÃO NOS CURSOS DE PÓS-GRADUAÇÃO. Relatório de pesquisa.

$<$ http://www.ead.unb.br/index.php/institucional/historico $>$.

Acesso em 05 fev. 2013.

XENOS, Michalis; PIERRAKEAS, Christos; PINTELAS, Panagiotis: A survey on student dropout rates and dropout causes concerning the students in the Course of Informatics of the Hellenic Open University. Greece: 2002

WALTER, Amanda Moura. Variáveis Preditoras de Evasão em Dois Cursos a Distância. Disponível em:

http://repositorio.unb.br/bitstream/10482/6532/1/2006 Amanda\%20Moura\%20Walter .pdf

Acesso em: 10 out. 2013. 


\section{APÊNDICE}

\section{APÊNDICE A - Questionário Evasão em Música}

\section{Evasão em Música}

Caro Aluno,

Gostaria de contar com a sua colaboração para responder o questionário que segue.

A aplicação deste tem finalidade acadêmica e os dados serão analisados estatisticamente e utilizados exclusivamente para fins acadêmicos.

Suas respostas serão mantidas em sigilo.

Por favor, responda todos os itens e caso tenha dúvidas, consulte a pesquisadora.

Muito obrigada!

*Obrigatório

\section{Perfil do Estudante}

\section{Nome * \\ Gênero * \\ Feminino \\ Masculino}

\section{Idade *}

\section{Estado Civil *}

Solteiro

Casado

Outro:

\section{Tem filhos *}

sim

não

Polo *

Anápolis

Buritis

Primavera do Leste

Ipatinga

Editar este formulário

Outro:

Qual era seu nível de formação antes de iniciar o curso de Licenciatura em Música? * Ensino Médio

Graduação

Pós-graduação

Você exercia alguma profissão enquanto cursava a graduação em Música? *

Sim

Não

Qual?

Trabalhava quantas horas por semana? * 


\section{Questionário}

A escala abaixo varia de (Discordo totalmente) a (Concordo totalmente). Leia atentamente cada item e selecione o ponto da escala que melhor caracteriza a sua percepção.

Não existem respostas certas ou erradas.

1. O Curso de Licenciatura em Música foi sua $1^{a}$ opção de curso no vestibular? * Discordo totalmente

Discordo

Nem concordo, nem discordo

Concordo

Concordo totalmente

2. Você escolheu cursar Licenciatura em Música por falta de outras opções de curso? * Discordo totalmente

Discordo

Nem concordo, nem discordo

Concordo

Concordo totalmente

3. Você procurou ler os materiais que informavam sobre as características do curso de Licenciatura em Música, como prazos, atividades previstas e atuação profissional? *

Discordo totalmente

Discordo

Nem concordo, nem discordo

Concordo

Concordo totalmente

4. Você tinha conhecimento de informática básica antes de iniciar o curso (ligar o computador, trabalhar com editor de textos, armazenar arquivos, entre outros)? *

Discordo totalmente

Discordo

Nem concordo, nem discordo

Concordo

Concordo totalmente

A escala abaixo varia de (Nunca) a (Sempre). Leia atentamente cada item e selecione o ponto da escala que melhor caracteriza a sua percepção.

5. Sentiu-se confortável em estudar sozinho? *

Nunca

Quase nunca

Às vezes

Quase sempre

Sempre

6. Você elaborou um plano de estudos com reserva de horários para realizar as atividades do curso? *

Nunca

Quase nunca

Às vezes

Quase sempre

Sempre

7. Achou fácil realizar as disciplinas, sendo elas, à distância? *

Nunca

Quase nunca

Às vezes 
Quase sempre

Sempre

8. Teve dificuldades de acesso à computadores ou internet? *

Nunca

Quase nunca

Às vezes

Quase sempre

Sempre

9. Durante o curso teve dificuldades em utilizar os recursos tecnológicos de informática (Internet, correio eletrônico, chat, fórum, recursos da plataforma moodle, dentre outros)? *

Nunca

Quase nunca

Às vezes

Quase sempre

Sempre

10. Sentiu-se apoiado pelo tutor/professor a distância? *

Nunca

Quase nunca

Às vezes

Quase sempre

Sempre

11. Sentiu-se apoiado pelo tutor presencial? *

Nunca

Quase nunca

Às vezes

Quase sempre

Sempre

12. Você teve problemas de relacionamento com o Coordenador do Polo? *

Nunca

Quase nunca

Às vezes

Quase sempre

Sempre

13. Sentiu falta do contato virtual com outros alunos? (e-mail, chat, fórum, etc) *

Nunca

Quase nunca

Às vezes

Quase sempre

Sempre

14. Achou o conteúdo das disciplinas difícil? *

Nunca

Quase nunca

Às vezes

Quase sempre

Sempre

15. Você teve dificuldades de realizar as atividades das disciplinas do Núcleo de Formação Musical? ( Ex: Percepção e Estruturação Musical, Instrumento Principal e optativo, etc) *

Nunca

Quase nunca 
Às vezes

Quase sempre

Sempre

16. Teve dificuldades de realizar as atividades das disciplinas do Núcleo de Educação Musical? ( Ex: Prática de Ensino e Aprendizagem Musical, Introdução a Pesquisa em Música, etc) *

Nunca

Quase nunca

Às vezes

Quase sempre

Sempre

17. Você teve dificuldades de realizar as atividades das disciplinas do Núcleo de Fundamentação Pedagógica? (Ex: Leitura e Produção de Texto, Teoria da Arte, etc.) * Nunca

Quase nunca

Às vezes

Quase sempre

Sempre

18. Achou difícil obter boas notas nas avaliações de aprendizagem? *

Nunca

Quase nunca

Às vezes

Quase sempre

Sempre

19. Você sentiu falta de aulas presenciais? *

Nunca

Quase nunca

Às vezes

Quase sempre

Sempre

20. Sentiu falta da presença física de outros alunos? *

Nunca

Quase nunca

Às vezes

Quase sempre

Sempre

21. Sentiu-se estimulado a participar das atividades em grupo? *

Nunca

Quase nunca

Às vezes

Quase sempre

Sempre

22. Você foi incentivado pela sua família a realizar o curso? *

Nunca

Quase nunca

Às vezes

Quase sempre

Sempre

23. Teve dificuldades em conciliar estudos e trabalho durante o curso? * Nunca

Quase nunca 
Às vezes

Quase sempre

Sempre

24. Você se organizou financeiramente para frequentar os encontros presenciais? Nunca

Quase nunca

Às vezes

Quase sempre

Sempre

25. Você procurou conciliar sua participação no curso com seus compromissos familiares? *

Nunca

Quase nunca

Às vezes

Quase sempre

Sempre

26. Algum problema de saúde te impediu de realizar o curso? *

Nunca

Quase nunca

Às vezes

Quase sempre

Sempre

27. O tempo determinado para você realizar as atividades das disciplinas foi suficiente? *

Nunca

Quase nunca

Às vezes

Quase sempre

Sempre

28. Sentiu-se apoiado pelo corpo técnico-administrativo do curso? *

Nunca

Quase nunca

Às vezes

Quase sempre

Sempre

29. Você teve dificuldades de acompanhar as atividades de formação musical? (Ex.:

aprender tocar os instrumentos; realizar atividades de percepção e criação musical)? * Nunca

Quase nunca

Às vezes

Quase sempre

Sempre

Se você teve outros motivos que o levou a desistir do curso, por gentileza, apresente-os: 
APÊNDICE B - Profissão exercida pelos participantes da pesquisa.

\begin{tabular}{|l|r|}
\hline \multicolumn{2}{|c|}{ Profissão } \\
\hline \multicolumn{2}{|c|}{} \\
\hline Músico & Frequência \\
\hline Administrador & 1 \\
\hline Agronomo & 1 \\
\hline Almoxarife e Comprador & 1 \\
\hline Carpinteiro & 1 \\
\hline Comerciante & 1 \\
\hline $\begin{array}{l}\text { Educador musical e projetos autonomos como professor } \\
\text { particular de música }\end{array}$ & 1 \\
\hline Empresario & 1 \\
\hline Escola de Música & 1 \\
\hline Estagiário em engenharia mecânica & 1 \\
\hline Fazia outra graduação ao mesmo tempo - Direito & 1 \\
\hline $\begin{array}{l}\text { Formada em Letras. Dava aula de português na rede } \\
\text { estadual de ensino. }\end{array}$ & 1 \\
\hline $\begin{array}{l}\text { Formado em Quimica, mas é concursado num curso } \\
\text { técnico em Música, portanto é professor de Música do } \\
\text { Estado de GO }\end{array}$ & 1 \\
\hline $\begin{array}{l}\text { Funcionário público Municipal e diretor de Grupo } \\
\text { artístico }\end{array}$ & 1 \\
\hline Graduação em Pedagogia. Professor de Música & 1 \\
\hline Músico prático, Orquestra e Professor de Música & 1 \\
\hline $\begin{array}{l}\text { Músico prático, trabalhava numa loja de instrumentos } \\
\text { musicais e professor de música }\end{array}$ & 1 \\
\hline Pedagogia & 1 \\
\hline Professor de História. Cursou graduação em Historia & 1 \\
\hline professor de musica & 1 \\
\hline Professor de Música & 1 \\
\hline Professora Formadora & 1 \\
\hline Técnica em enfermagem & 1 \\
\hline tecnico de manutenção eletrica & 1 \\
\hline vendedor & 1 \\
\hline Total & 1 \\
\hline
\end{tabular}


APÊNDICE C - Frequência do questionário.

1. O Curso de Licenciatura em Música foi sua 1ạ opção de curso no vestibular?

Frequência

\begin{tabular}{lc} 
Concordo & 6 \\
Concordo totalmente & 10 \\
Discordo & 5 \\
Discordo totalmente & 2 \\
Nem concordo, nem discordo & 2 \\
\hline
\end{tabular}

2. Você escolheu cursar Licenciatura em Música por falta de outras opções de curso?

Frequência

Concordo 2

Discordo 8

Discordo totalmente $\quad 15$

3. Você procurou ler os materiais que informavam sobre as características do curso de Licenciatura em Música, como prazos, atividades previstas e atuação profissional?

Frequência

Concordo 10

Concordo totalmente $\quad 11$

Discordo 1

Discordo totalmente 1

Nem concordo, nem discordo 2

4. Você tinha conhecimento de informática básica antes de iniciar o curso (ligar o computador, trabalhar com editor de textos, armazenar arquivos, entre outros)?

Frequência

Concordo 
5. Sentiu-se confortável em estudar sozinho?

Frequência

\begin{tabular}{ll} 
Às vezes & 5 \\
Nunca & 5 \\
Quase nunca & 1 \\
Quase sempre & 7 \\
Sempre & 7 \\
\hline
\end{tabular}

6. Você elaborou um plano de estudos com reserva de horários para realizar as atividades do curso?

Às vezes

Frequência

Nunca

5

Quase nunca

2

Quase sempre

1

Sempre 10

7. Achou fácil realizar as disciplinas, sendo elas, à distância?

\section{Frequência}

Às vezes

7

Nunca

8

Quase nunca

2

Quase sempre

2

Sempre 6

8. Teve dificuldades de acesso à computadores ou internet?

Frequência

Às vezes

Nunca

Quase nunca 
9. Durante o curso teve dificuldades em utilizar os recursos tecnológicos de informática (Internet, correio eletrônico, chat, fórum, recursos da plataforma moodle, entre outros)? Frequência

Às vezes 2

Nunca 15

Quase nunca 3

Quase sempre 2

Sempre 3

10. Sentiu-se apoiado pelo tutor/professor a distância?

Frequência

Às vezes 11

Nunca 3

Quase sempre 2

Sempre 9

11. Sentiu-se apoiado pelo tutor presencial?

Frequência

\begin{tabular}{lc} 
Às vezes & 7 \\
Nunca & 3 \\
Quase nunca & 1 \\
Quase sempre & 2 \\
Sempre & 12 \\
\hline
\end{tabular}

12. Você teve problemas de relacionamento com o Coordenador do Polo?

Frequência

Às vezes 1

Nunca 
Quase nunca 1

Sempre 1

13. Sentiu falta do contato virtual com outros alunos? (e-mail, chat, fórum, etc)

Frequência

Às vezes 6

Nunca 10

Quase nunca 2

Quase sempre 1

Sempre 6

14. Achou o conteúdo das disciplinas difícil?

Frequência

Às vezes 12

Nunca 7

Quase nunca 2

Quase sempre 3

Sempre 1

15. Você teve dificuldades de realizar as atividades das disciplinas do Núcleo de Formação Musical? ( Ex: Percepção e

Estruturação Musical, Instrumento Principal e optativo, etc)

Frequência

Às vezes 7

Nunca 12

Quase nunca 1

Quase sempre 1

Sempre 4

16. Teve dificuldades de realizar as atividades das disciplinas do Núcleo de Educação Musical?

( Ex: Prática de Ensino e Aprendizagem Musical, Introdução a Pesquisa em Música, etc)

Frequência

Às vezes 6

Nunca $\quad 8$ 


\begin{tabular}{ll} 
Quase nunca & 5 \\
Quase sempre & 3 \\
Sempre & 3 \\
\hline
\end{tabular}

18. Achou difícil obter boas notas nas avaliações de aprendizagem?

Frequência

\begin{tabular}{ll} 
Às vezes & 6 \\
Nunca & 9 \\
Quase nunca & 2 \\
Quase sempre & 2 \\
Sempre & 6 \\
\hline
\end{tabular}

19. Você sentiu falta de aulas presenciais?

Frequência

\begin{tabular}{lc} 
Às vezes & 3 \\
Nunca & 2 \\
Quase nunca & 1 \\
Quase sempre & 2 \\
Sempre & 17 \\
\hline
\end{tabular}

20. Sentiu falta da presença física de outros alunos?

Frequência

Às vezes 8

Nunca 6

Quase nunca 3

Sempre 8

21. Sentiu-se estimulado a participar das atividades em grupo?

Frequência

Às vezes 2

Nunca 3

Quase nunca 3 
22. Você foi incentivado pela sua família a realizar o curso?

Frequência

Às vezes

1

Nunca

3

Quase sempre

1

Sempre

20

23. Teve dificuldades em conciliar estudos e trabalho durante o curso?

Frequência

Às vezes 3

Nunca 2

Quase sempre 4

Sempre 16

24. Você se organizou financeiramente para frequentar os encontros presenciais?

Frequência

Às vezes

3

Quase sempre

3

Sempre

25. Você procurou conciliar sua participação no curso com seus compromissos familiares?

Frequência

Às vezes 2

Nunca 
Quase sempre 6

Sempre

14

26. Algum problema de saúde te impediu de realizar o curso?

Frequência

Às vezes 2

Nunca $\quad 17$

Quase nunca 1

Quase sempre 1

Sempre 4

27. O tempo determinado para você realizar as atividades das disciplinas foi suficiente?

Frequência

Às vezes 3

Nunca 9

Quase nunca 6

Quase sempre 2

Sempre 5

28. Sentiu-se apoiado pelo corpo técnicoadministrativo do curso?

Frequência

\begin{tabular}{lc} 
Às vezes & 5 \\
Nunca & 4 \\
Quase nunca & 1 \\
Quase sempre & 1 \\
Sempre & 14 \\
\hline
\end{tabular}

29. Você teve dificuldades de acompanhar as atividades de formação musical? (Ex.: aprender tocar os instrumentos; realizar atividades de percepção e criação musical)?

Frequência

Às vezes 
Nunca

Quase nunca

Quase sempre

Sempre
12

1

1

4 